\title{
THE OPAL SEA
}

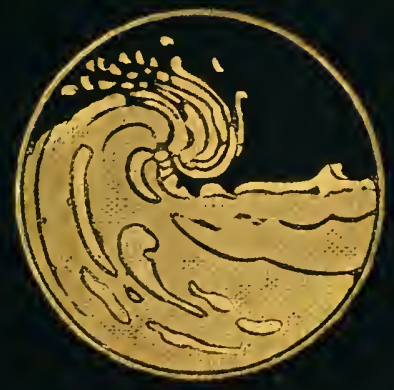




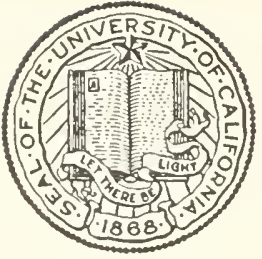

THE LIBRARY

OF

THE UNIVERSITY OF CALIFORNIA

LOS ANGELES 
Digitized by the Internet Archive in 2008 with funding from Microsoft Corporation 





\section{THE OPAL SEA}




\section{BOOKS by PROF. JOHN C. VAN DYKe}

\section{ART FOR ART'S SAKE}

University Lectures on the Technical Beauties of Painting. With 24 Illustrations. $12 \mathrm{mo}$. \$1.50.

\section{THE MEANING OF PICTURES}

University Lectures at the Metropolitan Museum, New York. With 31 Illustrations. 12mo. \$1.25 net.

NATURE FOR ITS OWN SAKE

First Studies in Natural Appearances. With Portrait. 12mo. \$1.50.

\section{THE DESERT}

Further Studies in Natural Appearances. With Frontispiece. $12 \mathrm{mo}$. $\$ 1.25$ net.

TEXT BOOK OF THE HISTORY OF PAINTING

With 110 Illustrations. $12 \mathrm{mo}$. \$1.50.

OLD DUTCH AND FLEMISH MASTERS

With Timothy Cole's Wood-engravings. Superroyal 8vo. \$7.50.

\section{OLD ENGLISH MASTERS}

With Timothy Cole's Wood-engravings. Superroyal 8 vo. $\$ 8.00$.

\section{MODERN FRENCH MASTERS}

Written by American artists and edited by Professor VAN DYKE. With 66 full-page Illustrations. Superroyal 8 vo. \$10.00. 



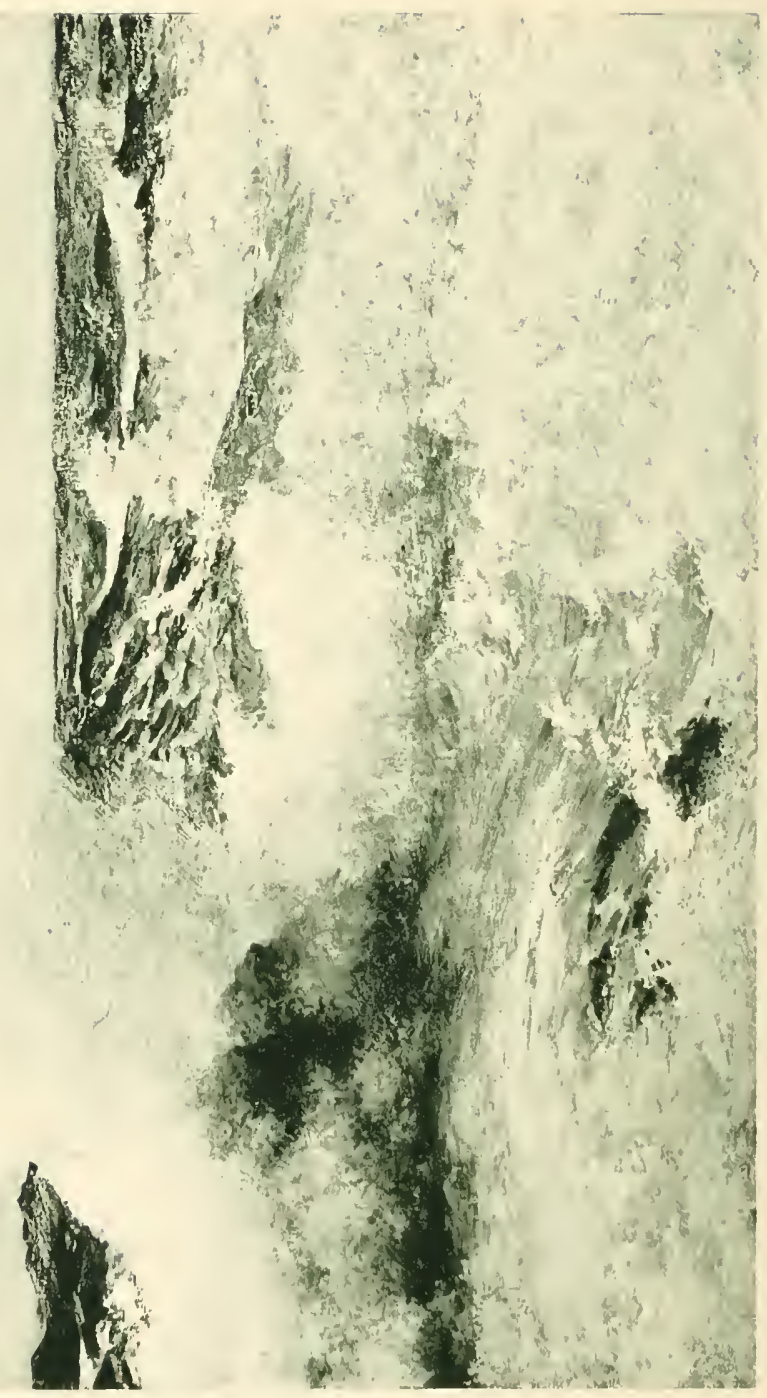




\section{B. GPAL $\$ E A$}

\section{$2+$}

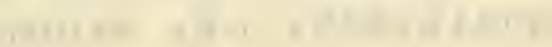

$$
\begin{aligned}
& \begin{array}{r}
\vdots \\
\vdots \\
\vdots \\
2 \\
2
\end{array} \\
& \dot{\overbrace{0}} \equiv \\
& \text { 经言立 }
\end{aligned}
$$

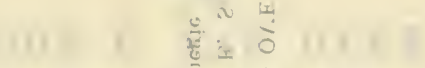

$$
\begin{aligned}
& \sum_{i=1} \\
& \bar{z} \pm \\
& \frac{10}{2} \\
& 25 \\
& =-\div \\
& = \pm
\end{aligned}
$$

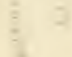




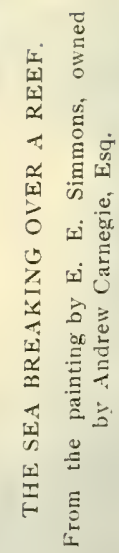




\title{
THE OPAL SEA
}

CONTINUED STUDIES IN

IMPRESSIONS AND APPEARANCES

BY

\section{JOHN C. VAN DYKE}

AUTHOR OF "THE DESERT," "NATURE FOR ITS OWN SAKE," "ART FOR ART's SAKE," ETC., ETC.

\author{
NEW YORK \\ CHARLES SCRIBNER'S SONS \\ 1906
}


CoPYRIGHT, 1906, BY

CHARLES SCRIBNER'S SONS

Published, March, 1906

TROW OIRECTORY

PRINTING ANO BOOKBINDING COMPANY NEW YORK 


\section{PREFACE-DEDICATION}

\section{Co}

\section{A. T.}

IT is the heat of July. Along this Dalmatian coast, since early morning, the white tops of the Velebit Mountains have been glimmering and quivering in the rosy air like phantoms of the mirage. The sky that started so darkly blue has trembled on to evening through every shade of lilac and silver, and the smooth Adriatic lying under it has shown no floor of lapis-lazuli, but in its place the pearl-like surface of the opal. Slowly undulating, gently moving, but with no flaw upon its face, the sea has thrown off, hour after hour, the mingled hues of the Oriental stone. Green of emerald and aquamarine, purple of amethyst, blue of sapplire, rose of diamond and gold of topaz, all have passed and repassed; and now at sunset, with every color fused into flame, the scarlet reflection of a cloud in the distant water gives the fire of the opal-the point of high light on its surface. Therefore why not the Opal Sea? 
Indeed, my title is not so fantastic as one might think. We have always heard of the sea as "decp blue" and fancied perhaps it could be no other color; yet if you look down upon it from a cliff where it flows over white rocks you will find it a shade of green, and if you plunge beneath the surfaee and open your eyes under water you will discover it is still another shade of green. Then there are great arms of the ocean that from their color are known as the Red Sea, the Yellow Sea, the White Sea, the Black Sea. It has many hues in different quarters of the globe. But none of these local colors is comparable in extent or continuance to the color reflected from the sea's surface. Whatever hue is in the sky, whatever tint may be produced by heat or cold, by sunlight or moonlight or cloud-light, the water mirror will give it back. The sea is not blue or grcen or yellow alone, but all the rainbow hues blended and fused by sunlight into iridescent fire. Therefore why not the Opal Sca? And, again, I mean by that title to suggest that this book, though it treats of seientific things at times, is, in design at least, a book of color and atmosphere. The splendor of the sea rather than its origin, its cartography, or its chemistry has been my aim. It may seem 
strange that in this material age one should think of the ocean as anything more than an element to be analyzed, a power to be utilized, or a highway to be commercialized. The beauty of the world has never been of great pith or moment to mankind. Its admirers are few, its destroyers are many. And those who cry out against wanton destruction, those who have seen forest and prairie and mountain wrecked, and every river of our native land blackened in the name of manufactures, now go down to the shore and, looking out from the rocky headlands, thank God for the unpolluted sea. Man has plowed that sea with ships, fought for it with navies, assumed command of it from time to time; but never because of its beauty. A more sordid aim has been his and made him quite oblivious to charm. $\mathrm{He}$ has pursued the golden will-o'-the-wisp, and Death has sailed with him. Will he never learn that happiness is not a matter of possessions, and that mental content, joy of heart, a love of loveliness, are more potent factors in human well-being than naval power or commercial gain? When the hurly burly's done, when the flower is frayed and torn, perhaps he may heed, but that will not be in our day. In the meantime the great ocean in all its glory spreads 
before us; the lights and colors of its sunwoven fabric are still ours; we still may know the beauty of the Opal Sea.

Not here alone by this Dalmatian coast is the wondrous play of light and color on the outstretched sea. By the home waters of the Atlantic, by West Indian strand and Peruvian headland and South Sea beach there is the same glint of flame and fire. The distant seas where once rode golden galleons, the still waters of tropic reefs where polyps rear castles of coral, the encircling waves of lone islands where seals lurk and sea birds clamor, are merely parts of the great whole. All the oceans are one. North or south of the line, at the equator or at the poles, around Iceland or around Formosa there is but the one water. And up and down the vast expanse, everywhere over its shining surface, with summer suns and rosy atmospheres, there spreads the violet light, the pearly color, of the Oriental stone. Therefore I ask again: Why not the Opal Sea?

Ragusa, Dalahatia.

$$
\text { JoHN C. VAN DYKE. }
$$




\section{CON'TEN'TS}

Chapter I. The Discovery.-Early fear of the seaSea tales-The phantom ship-The maelstrom-Cities under the sea-Fortune seekers-Sea-rovers and sealovers-First coasters-Hebrews, Tyrians and Sidonians -Phonician voyagers-Greek traders-Galleys of Carthage and Rome-Rise of Islam-Renaissance commerce-Venice at its height-Skirting the AtlanticBaltic and Icelandic voyages-The Western OceanColumbus and his courage-The new world-Balboa and the Pacific-Magellan and the extent of the seaThe vast Pacific-Exploration and conquest-Geographical limits of the sea-Scientific study of the seaThe original element-Forming of the sea bed-Origin of life in the sea-The organic in the inorganic-Michelet and the evolutionists-Mucus and protoplasm-The unthinking sea-Life and death-The sea's indifference to man-Wrecks of ships and empires-Repose of the sea-Beauty of the sea............... 1

Chapter II. Swirls of the Sea.-Currents in the ocean -Extent of land and water-Sea level-Disturbances of level-Effect of earth's attraction-The swelling sea -The tides-Cause of tides-Attraction of the moonHigh and low tides-Spring and neap tides-Western tide wave-How it travels-Its height-Wedged water ix 
- Tide in inland seas-The Norwegian maelstromScylla and Charybdis-Races and whirlpools-Bores of Colorado and Amazon-Tidal waves--Great waves in Pacific-Krakatoa-Waves from its explosionTravel of waves-Undulation and drift of waterOcean currents-The Gulf Stream-Japanese currentVariations of currents-Early beliefs about currentsFranklin and Maury-Trade Winds-Ocean currents following winds-Circulation of seas-Exchange of currents-Exchange in Red Sea and MediterraneanDifference in temperature a cause of circulation-Swirls and rings of the sea-Swirls of the air--Life-giving properties of change-Swirl of the solar system-The Milky Way a Sargasso Sea-The search for truth. . 24

Chapter III. In the Depths.-Surface effect of storms-Shallowness of currents-Depth of tides and tide theories-Stillness of ocean depths-Darkness of depths--In the pit-Intense cold of under watersOcean temperatures-The sea bed-Mountains in the sea-Volcanic and coralline formations-Pot-holes and chasms-Sea troughs-Sinks of ooze-Shore beds and their bottoms-Shore benches-Haunts of the octopus - Make-up of sea muds-Terrigenous deposits-Glacial ooze-Volcanic dust-Abysmal deposits-Pteropod ooze-Globigerina and Radiolarian oozes-Red ClayContents of sea pits-Deep-sea records-Ocean transparency-Clearness of Mediterranean, Carribean, and Pacific-Bottom reflections-Muddy bottoms-Mineral stains-Sea sawdust-Gulf Stream coloring-Local sea color-Salt particles in water-Effect of blue skySalinity and its effect-Coloring by depth-Beauty of sea color-Temperature as a factor-Color local and reflected..................... 48 
Chapter IV. The Great Mirror--Solomon's Brazen Sea-Roundness of the sea circle-Ship the center of circle-Rise-up of the horizon-Bowls of blue-Sea illusions-Limitless space-The two blues-Color as known to the ancients-The sea mirror-The darker image-Shadows on water-Reflections in ruffled seasThe sea under cloud light-Reflections in shadowed spaces-Light and color from sky-Sunset in the water -Muddy waters as reflectors-Effect of temperature on color-Color at poles and tropics-The opal seaSilver grays and twilight purples-The Mediterranean - The Dalmatian coast-At Spalato and RagusaOpalescent air and sea-Sea in early morning on Gulf of Corinth-Mount Parnassus-In the Cyclades-Sapphire waters-Opal seas in many latitudes-Coast of Mexico-Cold colors in tropics-Quality of light-Different tones-Dawn at sea-Spread of light-On ruffled seas-Coloring of sea at mid-day-Sunset colorings in water-Eastward lying waters at sunset-Moonlight on sea-The Angelus hour-The Angels Pathway-Our place in nature-Starlight on the sea-Guiding stars -Dark windless nights-The Blue Bowl....... 70

Chapter V. Ocean Plains.-Continuity of the sea -Its endurance-The Pacific from Mexico-Southern Ocean-Unexplored waters-Looking seaward from Mexican highlands-Ocean swells and their movements - Glassy surfaces-Region of Trade Winds-Surface movements - Modern ships and sea travel-The ship's furrow-Whiteness of foam-Crests of foam-Colored crests-Wave crests at night-Flung spray-Rainbows -The ship's wake and its silver light-Phosphorescent light-Fields of animalcula-St. Elmo's Light-Sca mirage-Fata morgana-The ship in the air-Effects 
of mist-White holizons-The mist veil and colorbeauty - Lunar rainbows - Summer nights on the Agean -Fogs at sea-Black fog-Fog effects-Icebergs and their color-Forms of bergs-Polar ice-fields-Snow at sea-Falling rain-Driving rain-Water spouts-Spouts, how formed-Evening light after rain-Land in sight -Appearance of land-Approach to the shore-Lagoon islands-Pacific islands-Coral groups-Romance of the South Sea islands-Concerning happiness..... 95

Chapter VI. The Wind's Will.-The disturbing winds-Skin of water drops-Covering of sea-surfaceStretching and breaking of covering-Ruffled seas-Sea before storm-Choppy sea-White caps-How they break-White caps to the swimmer-Waves with a half gale-Storm waves-Cyclones and thunder storms at sea-The "northeaster"-Spume and water dustFlying scud-Stormy seas from the cross-trees-Color of stormy sea-Forms of waves-Grace of waves"Waves mountain high"-Wave heights-Wind in English Channel-Along coast of Holland-Night with storm on North Sea-Drive of the wind-Storm in the Roaring Forties-"Gray-back" waves-Sailing vessels in heavy seas-Plunge of the ocean-liner-A great storm on the New England coast-How it begins - Rain, wind and rising surge-The great seas-The white-ridged ocean-Sea-gray coloring-Lighthouse and bell-buoy - The pound of waves-The subsidenceWrecks and wreckers-The victim-Flotsam of the wave-A sea horror-Tragedies of the sea...... 119

Chapter VII. The Wave's Tooth.-Sea barriersThe cliff wall-The blow of the wave on the cliff-Foun. dation-walls in deep water-The shelving shore- 
Friction of incoming waves-The break and recession of waves-Height of storm waves along shelving shores -Bell Light and Eddystone-The impact of wavesDestruction of cliffs, shores, and islands-Gnaw of the wave's tooth-Grit in sea water-Wear along cliffsBowlders at eliff base-Fate of the bowlders-Soft parts of cliff worn first-Spouting horns-Wave grottoes -Ocean caves-Within the caves-Weird lights and colors-Fiords-Victor Hugo's Lysefiord-Bays and promontories, how made-Towers along shore-Reefs and sunken rocks-The ground-down sands-Bars and necks of land-Lagoons and islands-Marsh landsIslands lost in storms-The Louisiana coast-Give and take of land and sea-Return of the sands from the sea $\rightarrow$ Sand driftings and dunes-Dykes and dunes as sea barriers-North Sea flooding Holland-Traveling sands -Villages destroyed by sands-Sahara sands-The sea at the foot of the cliff.................. 141

Chapter VIII. Sounding Shores.-Footprints of the sea-Dover Cliff and Sandwich beach-Old town of Sandwich-The meadows-Gray waters of the shoreGoodwin Sands and its wrecks-The wet beach-Half submerged flats of sand-Gray harmonies-Somber colors of North Sea-The Scottish coast of SutherlandCentral American beaches-Glitter and litter of the shore-Singing sands-Crescent beaches-Irregular beaches of stone and gravel-Strewn on the sandsShell beaches-White sands-Waves on the beachBeach combers-Forms of breaking waves-Grace of water movement-Color of waves-Water mirrors on the beach-Reflection of mirrors-Retreat of the water - Wave traceries on sand-Color of shore-Light effects and shore reflections-Moonlight along shore-Noc- 
turnes-Sound of the sea on the beach-Other sounds in nature-Recurrent beating of the sea-Suggestion of the sound-Science and sentiment........ 160

Chapter IX. Gardens of the Sea.-Growths of the sea different from those of the land-Conditions and place of growth-Peculiar adaptation-Strength and fitness of sea weeds-Grace of sea weeds-Swaying rock weeds-Patterned forms-Algæ of the greater depths -Extent of sea gardens-Growths along shorePopular classifications-Green alg:e-Blooms and net weeds-Blue-green and brown alga-Kelp and rock weed-Red alga-Dulses and mosses- "Floweranimals"-The plant likeness superficial-Marvels of design and color-Great variety of sea life-One-celled life-Sponges, their kinds and colors-Polyps-Sea anemones and corals-Coral colors and reefs-Jelly fishes-Sea-nettles-Medusoid types-Living ribbons and necklaces-Sea urchins-Star fishes-Brittle stars -Sea lilies and stone lilies-Holothurians-Sea cucumbers-Shell fish-Univalves and bivalves-Conches, oysters, clams-Scallops and cockles-CephalopodsThe pearly nautilus--The octopus-Size and equipment of the octopus-Crabs, lobsters, and barnacles-Their hard shells, how formed-Their defense and attackColor of sea life-Sea gardens in Mexican Gulf-Seen through a water glass-Tropical fishes-Red snappers, pompanos, sharks, porpoises-The chase and deathChanges in sea life-Testimony of the rock-Nature maintaining the slatus quo............ 177

Chapter X. Dwellers in the Deep.-Marine life in the great depths-Problem of light-Phosphorescence and luminescence-The violet rays-Other lights in 
the depths-Plankton-Lantern fishes with photophores-Grotesque quality of decp sea fishes-Oceanic pressure-Effect on fishes-Peculiar design of sea fishes -Voracious appetites-Defense and attack-The dismal existence-Coloring of bottom fishes-Surface fishes-The bluefish-Herrings and porpoises-Menhaden and mackerels-Movement of the schoolsFlying fish-How they fly-Vibration and sailingChased by the albicore-The capture-Bird enemies -The coryphene-Swiftness of porpoises-Speed of the sea rovers-Fitness to their element-Tarpons and tunas-Coloring of school fishes-Protective colorings -Changeable colorings-Coloring of the mackerels and coryphenes-The whales and their colorings-Enemies of the whale-The sea turtle-Seals-Their habits and growth-Killed for their beauty-All sea life destroying and is destroyed-Endurance of the type-What lies beyond ........................ 202

Chapter XI. Gray Wings.-The sea as the source of all-Sea birds and their voracity-The pelicansThe cormorants, shags, and divers-Chasing fish under water-Penguins, auks, and puffins-Long-legged waders-Flamingoes-The scarlet ibis-Storks-Dancing cranes-Shore birds-Turnstones and sand pipersSand pipers lost at sea-Finches and warblers in the shrouds of the ship-Land birds at sea-Equipment of the true sea wanderer-Muscling and feathering of sea birds-Enormous endurance-Gray coloring of sea birds-Terns, gulls, and their flight--How gulls liveThe frigate bird - The wonderful sailer-A sea pirateCatching flying fish-Frigate bird's bad reputation-His fitness for long flight--The wandering albatross-Flight feathers of the albatross-His sailing qualities-Where 
he lives-The tropic bird--His steering gear-Cape pigeons and whale birds-Wilson's petrel-The stormy petrel-Flight of the petrel-The untiring wing-Self reliance of the petrel-Joy in adversity-Persistence of life-Omnipresent energy-Fitness and beautyGray Wings a part of the plan........... 223

Chapter XII. Ships that Pass.-Coming down to the sea-The native element-Emotions by the seaThe sail-The disappearing ship-IVatchers of shipsShips that have passed-The butterflies of commerce - The harbor to-day-White wings and gray wingsThe full-rigged ship-Colors of her sails-A white yachting squadron-Colored sails of the Adriatic-Venetian fishing boats-The ocean steamer-The steamer putting to sea-The power of steam-The steady drive forward -Steaming through storm-The persistent enginesThe picturesque ship at sea-The battle-ship and our point of view-The common resting place of shipsTragedies of the sea-The sea not "rapacious"-Grim sea tales furnished by men-The real "horror" of the sea-The quest of gold and its results-Hardships of the explorers-Searching for gold at the northSunken treasures-Race hatred on the sea-The early carriers and merchantmen-Ocean liners of to-dayGrowing appreciation of sea beauty-Atlantic crossings -The supreme element-A false view-The lure of the sea-The suicide-Neither life nor the sea always storm-tossed-Maintenance of life-The sea the last to go-New eyes opening to the light-The beauty that shall be......................... 244 
THE OPAL SEA 



\section{THE OPAL SEA}

\section{CHAPTER I \\ THE DISCOVERY}

A FEAR of the sea was from the beginning. The early tribes that far back in the dawn of history dwelt by the eastern shores of the Mediterranean knew that fear. A great awe filled them as from shore and promontory they looked outward to the meeting-place of sea and sky. The western waves came beating in under the cliffs, surge following surge endlessly; but whence came they? Beyond the distant line all was mystery. No dark wings of ships, only the flame wings of the morning, had traveled there. The deep wrapped the earth on every side. The wise ones taught that the sun, moon, and stars rose out of it, and descended into it again; that it had once flooded all the land; that it was the infinite out of which all things came and back to which all things would return. No one could measure its extent; no one but felt its power to destroy. The little world 
Tales of the sea.
The phantom ship.

lifted, island-like, above an unknown waste; and man was no more than a shipwrecked sailor clinging to a scrap of rock.

When more familiar grown and many sails sank and rose along the horizon rim, the stories brought up from below the verge but added to its terrors. Beyond the Pillars of Hercules there was a great wilderness of water

"Which birds travel not within a year, So vast it is and fearful."

Nothing but water-water that could not be drunk by man or beast. Far to the south under a burning tropic sun, great calms spread over a glassy sea and there, caught in the silent web of heat, ships rolled listlessly upon the lazy swell and starving crews hauled and heaved and set sails that never filled, never caught a breath of air. No breeze to stir, no drop of rain to save-naught but the hot air to wither and the blazing sunlight to bleach. Beyond the region of calms, from an unknown sea still farther to the south-so the tale rancame the phantom ship that always sailed on the edge of a storm and was an omen of evil to come. It never came into port, it was only an uneasy ghost sinking and reappearing along the misty horizon; but it filled the mariner's 
soul with fear and added another haunting mystery to the sea.

At the north were terrors, more real perhaps, and quite as fearsome. Snow and ice eneompassed and wind overpowered. In the great storms there were waves that rose from out the hollows of the sea, beating and breaking the stoutest timbers and sending ships staggering downward to their ocean grave with sails still set and hands still elinging to the rigging. And there, too, was the great maelstrom compared with which Scylla and Charybdis were maelstrom mere eddies. Hundreds of leagues away the suction of the whirl could be felt upon the hapless ship, and once caught no erowding on of sail or bending to the oar could make headway against it. A monster polyp dwelt there and stirred the pool with waving tentacles and lived on human prey. Around him on the deep sea-floor were spar and rib and anchor, hulks of ships and dead men's bones and jewels gleaming out of hollow eyes.

Not there nor elsewhere was the bottom of the sea a longed-for dwelling-place. In the still Mediterranean men had noticed far down through the clear water the coral mounds, the sea-forests, and the flat valleys of ooze. And strange tales were told of voiceless cities that 
Cities under the sea.

Fortune seeliers.

had been seen beneath the wave, of silent palaces with towers and walls and blue-green grottoes all tenantless save to the soft flooding of the under-currents. Nothing lived or moved there but the monsters of the deep. It was a kingdom of silence, a realm of the dead. So deep-rooted was this belief that the very name, " mare," came to suggest the shores of the abode of the dead. It was not to be wondered at that with such weird whisperings the sea should seem a fear-compelling place.

Yet with all the dread of the great waste, with all the danger, there was a glamour about it that drew men on. Ships sailed away and never came back, but others took their place. Fame and fortune were alluring prizes. Beyond the Pillars were the "Western Islands" where no snow or cold ever fell, where the meadows and uplands surpassed the Garden of the Hesperides and the sands of the shore glittered with gold. Wealth and empire danced in the sailor's brain. Where the rainbow rested, at the end of the earth, there lay the crown and the treasure. Others there were-visionaries, adventurers, sea-rovers-who with no great love of possessions, still felt drawn to the sea. No matter how frightfully she buffeted the earthchildren, nor how violently she cast them 
forth upon the land, they always came trooping back to her. Many times that fateful man, Ulysses, suffered shipwreck and dire disaster; yet still he "languished for the purple seas." The pathway was dangerous-the Greek epics keep calling it the "shadowy," the "black," the "treacherous"; and the Hebrew books the "noisy," the "roaring," the "raging"-but still men ventured along it. It was a dream to the explorer, a means of gain to the trader, a refuge to the robber; and so the boats kept reaching farther seaward from port and cape to headland and island; and year by year more sails appeared flecking the floor of blue.

But many centuries were to elapse before men came and went freely along the ocean highways. The fear of the wave kept them back; the lure of the wave drew them on. How timidly and awkwardly the pre-Homeric traders coasted the eastern end of the Mediterranean! No one knows if the Chaldæo-Assyrians and the Egyptians did even that much. They may have achiered no more than the navigation of their own rivers. As for the Israelites, the sea was always a barrier to them, never a highway. They had ports in the Red Sea and carried on an Oriental trade to be sure, but not without Tyrian and Sidonian help. The Book of Kings

The first coasters. 
keeps the record that: "King Solomon made a navy of ships at Ezion-geber which is beside Eloth, on the shore of the Red Sea in the land of Edom. And Hiram (of Tyre) sent in the navy his servants, shipmen that had knowledge

Hebrews, Tyrians and

Sidonians.

Phanician voyagers. of the sea, with the serrants of Solomon. And they came to Ophir and fetched from thence gold, four hundred and twenty talents, and brought it to King Solomon." But Eziongeber, where the ships of Jehoshaphat were broken, was not on the Mediterranean; and Ophir is variously supposed to be on the coast of Arabia near the Gulf of Oman or in Farther India or possibly in Eastern Africa. In other words, the voyages were along the coast, not on the open ocean plains. In this respect they were quite different from those of Hiram and his predecessors.

What first started the early Phœnicians to the West may only be conjectured. From the hills of southern Lebanon at sunset one can see the black peak of Tróodos on the island of Cyprus, resting hazily against the evening sky; and perhaps this distant mountain suggested the first flight of the voyagers. Once at Cyprus it was easy enough to more on to Rhodes and Crete and from thence to the islands of the Greek Archipelago, or by the 
northern shores of Africa to Malta, Sicily, Sardinia, Massilia and Tarshish in Spain.

After the first ships of Phœnicia had traversed the seas of the West there were plenty of less courageous sails to follow in the wake. The spirit of navigation grew apace. Soon every rock-bound Ithaca had its fishing fleet and navy, and in extending its dominions exGreek tended discovery. From Lydia, Caria, Phrygia traders. and the far Cimmerian Bosphorus, from the islands of the Egean and the shores of the Greek mainland, the black ships of traders drove down the wine-dark seas. Westward the courses lay. Centuries before the Christian era there were sails from Tyre and Sidon skimming along the North African and Sicilian coasts, passing through the Tyrrhenian Sea, passing out through the Pillars, and up the coast to the gray waters of the English Channel. It was not long before the great Phœnician colony, Carthage, rose to power. Her merchantmen went hither and thither to distant countries and under Hanno (500 B.c.) her galleys darkened the uninhabited waters of western Africa. In the after-time, burdened with produce from the Ganges and the Nile, hundreds of sails were moving toward Rome. Long before the sea struggle at Actium, the 
The rise of Islam.

Renaissance commerce.
Mediterranean had known its rider; and long before the Cæsars passed away a shrewd knowledge of navigation had been attained.

Then followed that period of history known as the Dark Ages when human energy seemed crushed under the ruins of Rome, and eivilization for centuries lay still in a long swoon. The Goth ruled all the western shores of the Mediterranean but with no love for the sea; and the Eastern Empire was too badly crippled to battle successfully in hollow ships against Homeric elements. But a stronger power was rising in the East and moving westward like a tidal wave. Year by year the Moslem Empire spread until it embraced Syria, Egypt, the northern shores of Africa, Sicily, Sardinia, and Spain. The star and the crescent were in the ascendant, and Islam dominated the realm of waters as it did the realm of thought.

Slowly Europe roused from her long stupor. The old trade with the Orient was resumed and the colored sails of Italy went drifting along the Dalmatian coast and through the Greek islands to the East. The eourts of Europe had grown luxurious in a barbarie way; and Tenice, Florence, and Genoa were supplying them with silks, stuffs, spiees, perfumes, jew- 
els, glass, from Araby and India. The glamour of the East and the religious fervor of the West got into the brain and long files of crusaders, knights, warriors, adventurers came trooping to the Italian shores demanding transportation to the land of the Infidel. When that mad struggle was over there eame the long quarrels between Venice and Constantinople, the bloody encounters with Dalmatian pirates, the sea fights between the Genoese and the Venetians-all of them broken by many years of comparative peace and prosperity. Glorious days of sea triumph were those when the Doge went forth in the gilded Bucentaur to wed the Adriatic, when hundreds of argosies were tossing on the Mediterranean, and Venetian war galleys came and went in flocks that covered the seas! At its height the island city floated over three thousand merchantmen; Genoa was no mean seeond; and Pisa, Rome, Ravenna-all the coast towns of the peninsula -had the : ships in the carrying trade. Wherever a harbor offered and a town grew there the fleets of Italy cast anchor. And one by one each indentation in the coast came to be known and found its way upon the maps.

But, again, all this was skirting the shore or following well-traveled roads of the sea from

Tenice at its height of power. 
Skirting the Atlantic.

Toyages to the Baltic, Iceland, Greenland.

one port to another. It was navigation on an inland basin where the promontories, capes, reefs, and islands were well known. Beyond the land-locked Mediterranean the voyages were less frequent. True enough, the early Phœnicians had passed through the Straits and had found their way, "through the misty sea of darkness lying under the Bear, who alone is never bathed in the ocean," to England. Later on the Massilians had ventured farther into the North Sea in search of furs and amber; and the Romans had reached the far Baltic. The Western Islands were known, there had been explorations down the coast of Africa, and, though the Mediterranean people knew it not, the Northmen had sailed in their open boats to Iceland, Greenland, and thence on down the American coast. But no European of the Continent as yet knew the western shores of the Atlantic or so much as dreamed of the rast new world.

How very strange that after centuries of association the knowledge of the sea's extent should have been so limited! The earth was round in spite of what the Papacy might think and many navigators believed it in theory; but where was the heroic soul to put it to the proof! And was it a round of earth or 
merely endless water? There were whispers of a vast sea to the west where ships, entrapped Tales of the Western in fields of sea weed-caught like flies within Ocean.

a mesh-could neither go forward nor backward, but perished miserably. Was all the waste where the sun went down of that complexion? No one knew; no one could say. And no one eared to be the first to venture. The sea had grown familiar since Phœnician days, but it still had its terrors.

At last Columbus! Whatever clse he was or was not, however just the criticisms of those scientific historians who would read flaws in his title to fame, at least he was no coward. He put courage in his purse the day he faced the western ocean. Calmly he sailed beyond the "Blessed Islands" of the Greeks, beyond "the extremities of the West and East" of Aratus, beyond "the green earth's utmost bounds" of Homer. He did not know what perils might confront him. Dangers of tempest, of maelstrom, of evil spirits, of the world's ending-place were about him; but he Courape of held his course. The Sargasso Sea enmeshed him, his guiding stars forsook him, his compass apparently swerved from the pole, his crew grew mutinous; but he would not turn back. $\mathrm{Ah}$ ! the supreme fortitude of that man sailing

First voynge of Columbus. 
The new world.

Balboa and the Pacific. week after week into the unknown with nothing to support him but his own stout heart!

Success came when defeat was almost an accomplished fact. A new world had been discovered and given to Castile and Leon, but Columbus never for a moment imagined it was anything other than the western portion of the old world. The most that he sought was a shorter route to India by way of China. He thought he had discovered the outlying islands of Asia. No one had so much as imagined the presence of the two Americas or the infinity of waters that far beyond reached to the sunset lands of Cathay.

A few years later what must have been Balboa's wonder

\section{"when with eagle eyes}

He stared at the Pacific-and all his men

Looked at each other with a wild surmise Silent, upon a peak in Darien."

The Pacific was before him-the Pacific, whose farthest limits are mystery even to this day, lay shimmering in the sunshine. It would be strange, indeed, if such a sight had not given him pause. There is that in immensity which commands respect and something in vast $e_{x-}$ panses of light and color that makes for reverenee. Certain it is that if one have any finer 
feeling in his soul, it will come bubbling to the surface when he sees for the first time the Pacific. The discoverers were men of iron, but they were moved. Balboa wading waist deep Effect of the South ite into the water, sword and shield in hand, and discoverers. claiming the great sea for Spain-Spain that to-day can claim nothing there-was he not pathetic in his earnestness? And the stanch Magellan, he who after many struggles finally burst through the straits that bear his name, shed tears as the majestic waters swam into his ken. Stout conqueror's they were, but in the presence of the Southern Ocean small wonder that, for the moment, they felt themselves the conquered.

They were brothers of one blood-Columbus, Balboa, and Magellan. Courage and grim determination were theirs, and all were such stuff as heroes are made of. Once through the Magellan around the straits Magellan headed across the wide sea, and nothing could make him change his course. Starvation and disease went with him, but he never swerved. For more than ten thousand miles he sailed without knowing if he should ever again see the mainland rise up from the ocean's rim. Three months and twenty days he fought down fear, and in all that time never a glimpse of any land, save two small uninworld. 
Extent of the sea.

The vint Pacific. habited islands! How often he must have been harrowed by the thought that perhaps the theories were wrong, that possibly the world was not round but an unending reach of water upon which he had gone too far ever to return! To be lost on the land, in forest or on mountain, is discouraging enough; but to be lost on the $\mathrm{Pa}$ cific, in 1520-that is quite another affair.

Eratosthenes was right; the earth was a globe. But what philosopher ever imagined that it was so large! Homer was right when he sang of the "mighty flood," but he was thinking of the insignificant Mediterranean. What poet had imagination enough to picture the vastness of the Pacific! Many had surmised the truth but none had realized its extent. When the caravels of Columbus had sailed and returned the wise ones of the Renaissance were astonished by the story brought home. It seemed impossible that there could be so much water. And still the girth of the seas was uncomprehended. It was only when Мagellan's Santa Vittoria had circumnavigated the globe and dropped anchor in the bay of San Lnear that a realization of the world of water began to dawn. The Atlantic was astonishing enough in all conscience; but the Pacific was overwhelming and dumbfounding. 
Men knew at last whither the sea led traveling to the east or the west; but toward the poles still dwelt mystery. The valorous were eager enough to explore seas and coasts now that they were sure of finding land if they kept on sailing to the west. Portuguese carracks, Spanish galleons, English fleets went seurrying hither and thither, elaiming land in the names of their sovereigns and fighting with eacli other for the possession of what they could not hold. Scores of voyages were undertaken; the Cabots along the North American coast, Pizarro and Valdivia on the Pacific, Willoughby and Davis toward the North Pole, Cortereal, Frobischer, Hawkins, and Raleigh in different direetions, on conquest or discovery bent. At the south the Brazilian and African coasts were explored, Drake again circumnavigated the globe, and with Cook the South Sea became better understood. The geographical limits of the ocean were then tentatively fixed upon the map; and that outline has not been greatly changed in Geographical limits attained. these later days.

Long after the passing of the explorers, the slavers and the gold seekers, long after the period of discovery in the large, came the scientific exploration of the sea. This included not only the accurate charting of the great

Voyages of explorution and conquest. 
Charting of the sea.

Scientific study of the ocean.

waters with their islands, reefs, and shoals, but the sounding of the depths and the mapping of the ocean bed twenty thousand feet below the surface; not only the study of its winds and ealms but the movements of its currents and the changes in its density and temperature. Since the eighteenth century began, all features of the ocean-from its coral islands built up to its rocky shores pulled down, from the glowing equator producing, the energy of the great sea currents to the icy poles whose chilling streams restore the equilibriun, from the tides that swell the bays and harbors to the evaporation that drinks at the sea's surface - have been pried into and exploited. As for the color and light of the wave, its rise and fall and motion, they are no longer mysteries; the flora of the shallows and the fauna of the depths have been classified; and even the minute forms of life that show only as phosphorescence upon the sea's surface have come under the microscope, have been analyzed and differentiated in the laboratory.

Apparently all is known to us and the sea has no further secrets to reveal. And yet in a vague way we feel sure we are only on the threshold of its understanding. The story of creation becomes more intricrte as we advance. 
For perhaps the sea is the one original element and out of it have come all the others. In its The origidepths far down in the chill waters beyond our light and beyond our life, the rock strata of the earth may have been molded into shape. Centuries of time would have passed while the outworn shells of sea life were falling from the surface to the bottom and, with meteoric iron and star dust, forming the body of the rock strata. Centuries again would have passed while the slow-moving water was rubbing the strata into form and pressing it into substance by its enormous weight. At last, when its time was come, perhaps the great sea bed began to rise. The lateral pressure of the earth's crust forced it upward inch by inch, foot by foot, through a long series of years until finally the black slimy nose of the bed emerged from the water and became an island. Another age and the island had become a portion of a continent, and had baked hard and dry in the sunlight. Still another age and perhaps the nose had lifted into a mountain ridge, wearing away by erosion, and thus finding its way by the rivers back to its early home in the sea.*

* Such was the theory of science only a few years ago, but to-day the scientists are beginning to modify this view a little as regards the abysmal depths, while main-

Forming of rock layers in the sea bed. 
Not the dry land alone but the life of the

Origin of life.
The organic in the inorganic. globe, did it not also come up and out of the sea? Oceanus was the parent of the gods. He was the beginner, the original, from which all things sprang. Merely a pretty myth, it may be said. Yes, but myths are incorporated traditions-early beliefs of mankind. Perhaps there was a time when there was naught but the omnipresent sea, circling as a flashing ball in the solar system. Perhaps it was then a mass of life, and there was no inorganic matter existent until some of that life began to die. The skeletons of the dead that sank through the waters and hardened in a mass at the center, were the first formed strata of the solid earth. The trail of the organic is still apparent in the inorganic. Leonardo da Vinei recognized the sediment of the sea in the shell layers of the Apennines; and the blocks of the Colosseum at Rome, the pyramids at Ghizeh, still show these minute shells under the microseope. The Alps and the Andes are but so much hardened ocean ash, and perhaps the

taining the give and take of land and sea as regards the shallower depths. That our present dry land was once under the sea is hardly to be questioned, but that the present deep sea bed has ever been thrust up into land is open to doubt. 
whole earth is but the compact mold of dead things.

When Michelet revived this idea of Thales that the sea was the beginning of life, that its very atmosphere, so to speak, was an opalescent mueus, alive and eapable of development in itself, the thought was considered somewhat fantastie; but since then have not the scientists put hands upon this very coneeption and used it as an illustration in argument? Is not the opalescent mucus of Michelet the protoplasm of the evolutionist? And the sea is filled with it. Often when sailing in the tropies the watcher lying along the bowsprit sees down through the blue-green water drifts and skeins without number of this thin mucilage, receding by steps into the abyss and extending for many miles in every direction. The poles possess it in common with the tropies. The sea life lives upon it and is perhaps bred from it. It is the lowest form of life. No other element than water eould produee it or support it in such quantity.

And yet with these powers of life, these potentialities of ereation, how sublimely unconscious in its workings seems the sea! Great spawns of life go out from it, species by the hundreds of thousands; they disappear like

Mucus and protoplasm.

Michelct

and the anslution

2st. 
The unconscious sea.

Laws of life and death.

Earth broods. mists in the sun, they reappear like mists; but their coming and their going are one and the same thing to the great Mother. Never has she done more for her offspring than to give it facilities for existing and expedients against sudden death. Each one of her children has its peculiar adaptation enabling it to seek and gather food and brave its enemies by feint or flight or breed. But having once fitted them for the conflict she abandons each species to its fate, leaving it to live or die as it may or must. The equipment of the flying fish, the octopus, the sea lily, the common kelp, is each complete in itself; therefore, let each work out its own salvation or destruction. Death is not the unexpected. All through the kingdom of the sea some must die that others may live. Continually is life sustained by life destroyed. It is the law of being and the Mother of the Wave Myriads never puts forth a hand to restrain or check it. She is wholly indifferent.

For the creatures of the land-the creatures not of her spawning except perhaps in the early days-the sea has, if possible, even less care. They belong to a different brood and have no adaptation to the water. They cannot swim in the depths, they are not able to breathe the ocean atmosphere, and the food of the ocean 
plains they gather only by strategy from the surface. The sea knows them not.

Above all she never knew man-the most unseaworthy of all the earth-brood. He has fancied that she was his enemy, that she wilfully devastated his coasts and destroyed his fleets; but the sea indifferently beats whither it listeth, and if it break the ribs of a ship it shows only how ill adapted was the ship to the sea. What does a cockle shell in such an element? All man's commerce and eonquest, all his ventures in civilization, all his philosophy, science, and art have been as nothing unto her. $\mathrm{He}$ has sent forth fleets of triremes, earracks, feluceas, indifference to man. galleons, ships of the line; he has founded empires by her shores and peopled cities by her bays; but these have made no impression upon her. The destruction of Egypt and Assyria, the fall of Tyre and Sidon, the conquests of Alexander, the vast holocaust of Rome never so much as eaused her a quiver. Her waves lapped the blood from the steps of Carthage in the days of Hamilear and lapped the weed on the same steps when all was silent in decay. Her waters bore the transports of the believing crusaders going to the Holy Land, and they also bore the black fleets of the Barbary corsairs on robbery and murder bent. What mat- 
Wrecks of ships and empires make no impression.

Repose of the sea.

ter to the sea who they were or whither they went! A thousand ships go down to the bottom as snow flakes fall and melt into a mountain lake, but the sea does not change color. She is inured to life; yes, and she is inured to death. All things of earth may come and go. But the sea lasts. There as at the dawning of the first day the great Mother rests, calm, cold, unconquerable.

Yet men quarrel for her possession and talk vainly of being " rulers of the wave," as though the sea were more subject to rule than the open sky! One race of coasters drives another race from the pathway of commerce and thinks thereby to gain control. But power and mystery and death are still there. Vast possibilities are always hovering on the face of the waters. For many years the waves lie still and seem to slumber and then in a night they rise up in storm to engulf and strangle. It is but a momentary happening-a mere accident. An area of water is wrinkled by the winds and other portions of the sea are not even aware of it. The great depths are as unruffled as ever. At heart eternal calmness, serene repose are always with the sea.

And always eternal beauty. In every clime and in every season, from dawn to dusk, from 
dusk to dawn, it has the stamp of supreme beauty. Immensity and power are there, grace and rhythm of movement run with its waves and currents, light and color give it brilliancy and splendor. Each wind that ruffles it shows a new purity of hue, and each cloud that passes over it a new depth of reflection. The rounded heavens use it as a mirror, the stars are set The beauty like jewel points upon its bosom, and the golden of the sea. sun flames from the bright incline of each ocean swell like a mighty topaz shot with fire. $\mathrm{Oh}$, the beauty of the sea! The full-rounded sweep of it! The deep transparency of it! The wondrous harmony of it! The whole life of the world lies there conserved by its own energy-serene, indestructible, eternal. 


\section{CHAPTER II \\ SWIRLS OF THE SEA}

THE ancient tradition that a great river in the sea ran about the land, circling it like a ring, seems to the people of to-day an apt instance of early error; and yet it was not such a wild conjecture, not so far from the apparent truth. Off from the western coasts of Europe and Africa the Phœnicians knew the currents of the ocean that helped or hindered their fartraveling ships. They knew there was a vast circulation through the seas; and wherever on

Currents of the sea. distant island shores their vessels touched they heard tales told of the blue beyond with its mighty streams eddying about rocks or whirling downward into maelstrom depths. These tales (grown colossal by frequent tellings) finally became beliefs with the primitive races; the ocean was regarded as an unending strom, and the land little more than a tangible something anchored in the center of the swirl. It was a very little world, a

"precious stone set in the silver sea".

with wild waves fretting at its edges. 
Even at the present time humanity has difficulty in comprehending that the earth is solid, that it is far greater in bulk than the sea, and that its hollows and depressions hold the sea as in a shallow dish. Superficially looked at the water has many times the bulk of the dish, but not the less it is the dish that sustains. It holds the water and holds it with a flat surface. When the wind blows the surface is ruffled; when the dish itself is shaken the water is rocked into tidal waves. But these are momentary disturbances. Generally speaking the surface is smooth and practically flat.

Flat but not everywhere level though it looks so to the eye. In sea musings when gazing out upon the great plain we are continually reminded of the saying about "water seeking its level "; but it would seem as though the saying were more familiar than accurate. There is, for instance, a variation between the levels (not the tides) of the Atlantic and the Pacific at Panama which has been vaguely regarded as a possible difficulty in the way of the proposed inter-oceanic canal. There is also considerable variation in the mean sea level owing to difference in atmospheric pressure over different localities. And again local disturbances such as winds, may alter the level tempo-

Extent of land and water.

Sea level 
Disturbances of the level.

Effect of earth's attraction. rarily. The height of the Red Sea is lowered or elevated as the northwest wind blows the water out of the sea basin or not, the estuary of the Rio de la Plata is continually varying in level with the direction of the wind; and, indeed, it is a commonly observed happening for water to be wind-driven in or out of almost all bays and harbors. But these again are inequalities of a temporary character.

There is a greater variation in the Indian Ocean around the head of the Arabian Sea, where the water is supposed to be drawn up and out of the spherical by so much as three hundred feet-it is computed by some scientists as even more. This almost incredible elevation is accounted for by the attraction of the Himalayas. Possibly the Andes, that stand with their feet in the ocean, produce a similar effect upon the waters of the Pacific; but certainly the man before the mast has never seen it, and the navigator in the chart room has never made note of it. Nor is there any great certainty about the upward pull of the Himalayas. That the hydrosphere is drawn out of the spherical by earth-attraetion, or flung up in equatorial ridges by the spinning motion of the earth, is something as yet quite problematical.

The change of level brought about by the 
tides is popularly supposed to be a surface movement, but it is not the less of far-reaching effect. Possibly the tide was what Mahomet called "the swelling sea," for apparently the sea does swell and advance with the incoming water. For six hours it floods in upon every harbor, bay, and ereek, creeps up the beaches, rises along the dunes, and climbs the walls of the cliffs; then for six hours, just as quietly it ebbs and slips away from beach and inlet, leaving its trail of alga and sea life behind it on the shore. The fisher-boy, as he rocks in his boat, watches it rise twice each day, sees it linger for a time, sees it disappear, and dreamily wonders from what depth it came and to what abyss it returns. And why, he asks, does it come in each day an hour later?

The cause of the tides scems to have been correctly divined by Newton. His generalization of the law of gravitation apparently accounts for the disturbance; and the moon and the sun with their attractive powers are accounted the disturbers. The moon, by reason of its nearness, has an influence upon the earth of more than double that of the sun. The solid surface of the ground apparently does not rise to its attraction, but the waters of the sea do. The direct pull upon the waters which are 
The attraction of the moon
High and low tides the nearest to the moon, draws them out of the spherical on the near side of the earth, and draws the earth itself away from the waters on the far side. The result is a bulge or heaping up of water along those portions of the earth nearest and farthest removed from the moon. At the intermediate points, between the nearest and farthest remove, the pull of the moon is a force directed inward toward the center of the earth, and has a tendeney to flatten the waters in those regions. The result here is a depression or hollowing instead of a bulge. Thus with the water high in the places nearest and farthest from the moon, and low at the intermediate points, we have the sea raised above its normal level in some places and depressed below its normal level at other places. These elevations and depressions are what we call " high" and "low" tide.

There are really four tides a day instead of two-the moon and the sun eausing two tides each. But the solar tides are so much smaller than the lunar, and so largely merged in the latter, that they are not usually noticed. The influence of the sun is very noticeable, however, when it joins with the moon (that is twice a month) and there is a pull together. This results in the "spring" tides which are always 
very high. On the contrary, when the pull of the sun and the moon are at right angles to Spring and each other (that is at the first and third quarter of the moon) and have a tendency to connteract each other's influence, we have the "neap" tides which are always low.

If the globe were entirely covered with water of uniform depth the tide would follow the apparent course of the moon from east to west and complete the circle of the globe in approximately twenty-four hours. That is what it endeavors to do now; and in the Antarctic, south of the Continental extremities of Australia and Anerica, it is supposed to accomplish it. But farther north, where humanity is able to observe its movements, it is held back and turned from its course by inequalities of ocean depths, by shoals and reefs and coast lines along continents, so that it takes nearly twenty-five hours to accomplish its round, and hence arrives an hour late each day.

What is known as the "primary tide" is supposed to start from the deep central waters of the Pacific. It travels westward toward the Indian and $\Lambda$ tlantic oceans at the rate of a thousand miles an hour. When it meets with the opposition of shallow seas and coast lines portions of it are turned back, reflected toward 
How the tide travels.

\section{Height of} tide wave.

Wedged water. the American continent. In the Indian Ocean it is greatly retarded by island groups and narrow straits. In the North Atlantic it is broken again by shoals, by pockets like the Gulf of Mexico, and passes like the English Channel, until its movement as a single effect ean hardly be followed.

From its enormous mass and rapid movement this tide wave might be thought to have great height, but such is not the ease. In the Southern Pacifie it does not average more than from two to five feet, and that may be considered its normal height; but when a tide five feet in height is driven against a shore at the rate of one thousand or even onc hundred miles an hour, it can be easily imagined that there would be a great rush of waters up the slope. The eastern coast of North America which receives the full force of the Atlantic wave, has a tide of from five to twelve feet; and its bays and river mouths, where the water enters at wide entrances and is gradually driven into a narrow upper harbor, have a flood tide much higher. At the mouth of the Bay of Fundy the tide is eight feet in height; at its farther end this same tide is wedged and pushed up to a height of sixty feet or more. In the Bristol channel the flood tides reach up forty feet, 
and on the coast of France even higher than this.

On the contrary the large bays or seas with small ocean entrances, like the Mediterranean, are not affected by the main tide waves, but have slight tides of their own. At Corfu or Malta, the Mediterranean is practically tideless, but at Venice, at the head of the Adriatic, where there is a heap-up of waters, one finds a foot or more of rise, and in the Gulf of Gades from three to eight feet owing to the formation of the coast. Even comparatively small seas or lakes are disturbed by the moon and have some tide-Lake Michigan, for example, rising and falling about three inches a day.

Many, if not all, the phenomena of rushing water in river mouths or about reefs or narrow channels are due to the action of the tides. The famous maelstrom off the coast of Norway, which the writers of an earlier day employed so successfully in fiction, is really only an arm of the tide thrust violently between two of the Lofoden Islands, and causing a whirlpool which is reversed at every new rising. It is said to be very impressive as scen from the cliff of Voero looking down clear and sheer, and to be forceful enough to carry down whales in its funnel; but the tremendous whirl of

The Noruegian maelstrom. 
Scylla and Charybdis.

Races and whirlpools.

water fancied by Poe never had an existence in fact.

Tidal currents are responsible for all the fearsome whirlpools of antiquity. Scylla and Charybdis,

"The implacable Charybdis lashing the stars with its waves":

are still to be seen in the Straits of Messina. The agitation of the water is caused by the ebb and flow of tides through a narrow channel; and, though it is said to be dangerous to small craft, we are told that the conquerors of Sicily, more than once, swam their horses through it. The eddy of the Strait of Euripus, near the island of Eubœa, that in the Gulf of Bothnia, or the swift currents like the Blanchard Race which Victor Hugo employs in his Travailleurs de la Mer, are all eaused by high tides that produce tide rips and funnel-shaped whirls.

These races and whirlpools are interesting to follow because there is nothing more fascinating than the slip and glide of water, and even the come and go of the tide on the beach has a charm to those who watch; but they are usually not so dangerous as they look. To be sure " the hungry tide"- - though it never hun- 
gers-has been held responsible for many a sad sea-tale due to human carelessness; but the ordinary tide is quite harmless and floods in as softly as the moonlight over sunset prairies.

This, however, cannot always be said about the most violent of the tidal manifestations as seen in the mouths of certain rivers. A "bore" is not only fascinating but it may be very dangerous to shipping. It is usually "bore." caused by the inward rush of the tide water opposing the slow outward movement of the river water. The tide is at first driven in and wedged to a great height by the narrowing shores. It then encounters the river water, pushes it up to a flattened angle, and finally breaks over it and on it with a foam, a dash, and a roar. It may take other forms from other causes, but it is usually a breaker, not dashing up the beach, but dashing up the river mouth over the water of the river. Sometimes, as at the final exit of the Colorado, this breaker comes forward with great power. At the mouth of the Amazon it reaches a height of sixteen feet (it is said to be even higher) and the bores of the Tsien-Tang-Kiang and the Ganges are both famous and dreaded. For the breaker whether upon the bay or upon the coast has a crushing blow that ribs of steel and walls of

"Bores" of the Colorado and the Amazon. 
Tidal

waves.

Great waves in the Pacific.

rock will not always withstand. The force of water is almost incalculable.

There is another wave occasionally seen on the ocean that is called a "tidal wave" though it has nothing whatever to do with the tide. It is usually a wide, far-traveling undulation set in motion by some shock to the sea basin such as an earthquake. These subterranean disturbances sometimes spread over a vast area and set in motion waves that travel thousands of miles with wonderful velocity. In $187 \%$ one of these waves started on the Peruvian coast of South America, swept across the Pacific five thousand miles to Hawaii, and even at that distance maintained a rise and fall of some thirty-six feet from trough to crest. 'This was not so great as the earthquake wave of 1868 which, from the same region, traveled the $\mathrm{Pa}$ cific in a curved ring of perhaps eight thousand miles in length - traveled at the rate of five hundred miles an hour-and ran up on shores ten thousand miles away with a breaker crest thirty feet in height.

The distance which waves will travel when set in motion by violent disturbances is, again. something almost incalculable. The explosion of Krakatoa in 1883 produced ocean ridges one hundred feet in height that rode over the 
neighboring islands, and were felt on the shores of South America thousands of miles away. The relocity of these waves was several hundred miles an hour-not equal to the air waves set in motion by the same shock because impeded by islands, continental shores, and shallow waters; yet still an amazing rate of speed. The waves themselves for all their destructiveness must have been wonderful walls of water-upright walls almost like those thrown to the left and right when Israel passed explosion through the Red Sea, dark blue walls as though fashioned from lapis-lazuli, walls crested with dazzling white avalanches of foam, continually curling and breaking along the blue apex.

Of course it would be quite impossible for water itself to travel at any such terrific pace as five hundred miles an hour, and from the phrase "a wave travels" it must not be inferred that there is an actual movement or translation of, say, Pacific water to the shores of the Atlantic. The movement is apparent only; not real. It is the undulation that travels, not the water. A ship on the surface of a swift-moving wave does not drive ahead. It merely rises as the wave passes under, and falls as it passes out and away. The wind passing over the tall grain stalks in a Minnesota wheat 
Undulation.

Drift of water.

Drift of wreckage. field produces a wave in the stalks corresponding to the undulation of the sea, but the stalks do not move forward. Undulation and advance are not the same things.

There is, however, what is called "drift" which, as applied to sea water, means an advance. With wind and wave eontinually pressing against it, water will slowly "drift" from one portion of the ocean to another. Floating substances such as the loose planks of a ship, abandoned at sea, sooner or later find their way to the shore, to be eventually entombed in waves of sand; and the bottle with its fateful message from the lost, is perhaps picked up five thousand miles from where the wares first received it. But this drift of the sea is a very slow movement. For days the bottle bobs and pitches, the wreckage swings up and down, with wave following wave, and neither seems to change its place. Prevailing winds push them some, and finally a great storm swceps them into an ocean current. They move slowly even there, but it is largely due to ocean currents that floating objects move at all.

Now the ocean current that weaves a skein of color through the body of the sea, is quite a different affair from tide or wave or undulation. It is a distinet movement forward-a 
river in the sea that sometimes flows at the rate of two or three miles an hour and flows for several thousand miles before disintegrating. The violet-blue Gulf Stream of the Atlantie is a typical example. It starts in the central Atlantic somewhere off the coast of Brazil, passes northwest into the Gulf of Mexico, thence up the North American coast and across toward Europe. In the Florida Pass it is fifty miles wide and very swift; at Hatteras it broadens and slackens; on the Banks it spreads out fan-like, is met by the cold Arctic currents and pushed eastward toward Great Britain and France.* A disintegrated remnant of it is drawn in upon and down the coast of Spain, back to its original starting point, thus making that great pool in the Atlantic called the "Sargasso Sea." It was this enormous slow-moving The Gulf eddy-the great Gulf Swirl-that so frightened the companions of Columbus by its drifts of weed gathered and held in the central portion of the pool. Long after the passing of

* There are those who deny that the Gulf Stream passes as far north as England or that it reaches Europe at all. It undoubtedly dissipates to a great extent at or near the Banks of Newfoundland, but that its warmth and waters reach and influence Great Britain and beyond is still believable. 
The Japanese current.
Other ocean currents. the discoverer, navigators still thought that no ship could pass through it or get clear of entanglements when once caught in that mesh of yellow-brown Gulf weed.

The Kuro Sivo or Japanese Current in the Pacific is the counterpart of the Gulf Stream. It starts in substantially the same way, swings up the coast of Japan and eastward across the Pacific to the Aleutian Islands and the coast of Alaska. Its effect upon Northwestern America is to make of the climate a something akin in dampness and fogs to that of Great Britain and Norway. A branch of this current turns down the coast of California, creating another Sargasso Sea in the Pacific, and making of California a climate somewhat like that of Spain.

These are the two currents with which the sailor has the most familiarity, but there are many others put down upon the charts of the Pacific and Indian oceans. The larger ones are the South Equatorial and Australian currents, the Brazilian, the Mozambique and the Monsoon Drift. Comparatively smaller are the Agulhas Current that sweeps westward around the Cape of Good Hope, and the Guinea Current, either of which, though slight by comparison, is mighty enough to command respect. 
What wide rivers of the sea run in the great Antarctic has not bcen revealed; and yet, so far as discovery has gone, the whole surface of the waters seems in motion with dark blue or graygreen currents, going hither and thither, backward and forward, seeking a resting place and never finding it. The direction, force, and speed of the currents are constant in only a very general way. Time was when they were Variations considered as unvarying in their movements as the flow of the Amazon or the Rhine; but it is now known that they are subject to many vicissitudes, dependent upon propelling forces that are continually changing.

These rivers of the sea early gave rise to strange stories about their origins, their violent entrances and exits, and the supernatural powers behind them. Even so late as the middle of the seventeenth century Kircher suggested that they were caused by a circulation of the waters through a great tunnel in the axis of the earth. ocean currents. He thought that the northern drift of the Gulf Stream was the inward draft of the Norwegian maelstrom, that the sea waters went whirling down the great eddy, passed through the earth, and were spouted out again in the whirlpool of the Gulf of Bothnia. This same Gulf Stream drift was believed by geographers in the eigh- 
Franklin and Maury.

The Trade II'inds.

teenth century to be influenced by the movement of the sun, and by others to be a continuation of the flow of the Mississippi River; but our wise Dr. Franklin made a more common-sense explanation in saying it was caused by the Trade Winds foreing the sea water into the Gulf of Mexico and that its ontward flow was but the natural working of the law of gravity. When the further common-sense of Lientenant Maury was applied to the oeean eurrents there was no longer any place for speculation or superstition.

Perhaps the ehief cause of all ocean circulation is the prevailing winds. By long and steady pressure of the winds exerted upon the surface of the waters the upper stratum is forced into a sluggish movement which gradually increases in velocity until a well-established bent or direction is given to it. The eurrent thus set in motion is not deep. On the contrary, it is a surface drift which affects the intermediate depths but slightly, and the great depths probably not at all. The winds that produce the chief currents are the wellknown Trades that blow steadily across the Atlantic from east to west. In the Northern hemisphere they are turned to the north and flow back in a counter current to the east; in 
the Southern hemisphere they are turned to the south and again find their way back to the east. The movement is substantially the same in the Pacific. The general westward movement prevails, and the winds are again turned back at the north and the south.

The main ocean currents follow, as closely as is possible for them, the direetions of these Trade Winds and seem to correspond with them in many ways. In the Atlantic the South Equatorial Current flows to the west pushed by the Southeast Trades. When it meets the coast of Brazil part of it is shunted off south to make the Brazilian Current and part of it goes to the north, enters the Gulf of Mexico, and with the North Equatorial Current afterward emerges as the Gulf Stream. Substantially the same thing takes place in the Pacific. The North Equatorial Current flowing west meets the Philippines and other islands, is bent northward, and finally flows eastward as the winds. Japanese Current; the South Equatorial Current bends south and east as the East Australian Current. All these currents eventually return upon themselves and complete the circle. Moreover, they all have counter-drifts running in opposite directions that help restore the equilibrium of the seas.

Direction of the Trades. 
Circulation of the seas.

Exchange of currents.

"Horizontal circulation" is the name given to the movement of the well-defined surface currents; whereas the creep of scattered bodies of water up and down, here and there, is known as the "vertical circulation." Possibly the one is but a slower manifestation of the other, and perhaps both have causes, aside from the steady blowing Trades, that contribute to the total result. One of these causes is undoubtedly difference in gravity. The seas of the tropies, for instance, are subject to vastly more evaporation than those of the polar regions. There is more evaporation than rainfall, and, consequently, an ever-growing gravity and decreased bulk. At the poles, on the contrary, with much snow and ice continually melting and very little evaporation, there must be a tendency to freshness. This means decreased gravity and increased bulk.

It is not possible for this difference between the polar and the equatorial waters to exist without an attempt at equalization. The great Leonardo argued that much long before the seas were charted or a theory of gravitation was advaneed. The result of the attempt at equalization is an exchange, an interehange. The waters of the north and south work underneath by current, drift, and gradual "creep" toward 
the equator; and the waters of the equator work forever along the surface, moving outward toward the poles.

There is a similar interchange of waters by force of gravity in the majority of inland seas. The eraporation from the surface of the Red Sea is estimated at eight solid feet a year, and from the Mediterranean in corresponding proportion. This is enormous, and is not compensated for by a sufficient rainfall or inward Interchange of waters in Red siea and Mediriver flow. Both seas would have crystalized into salt beds centuries ago were it not that through the Straits of Gibraltar and the Straits of Babel Mandeb a heavy salt water current goes out and a eurrent of lighter, fresher water pours in. Even now the salinity of those seas is very high and the exchanging currents of water through the entrances are hard pushed to maintain normal conditions.

In a like manner difference in temperature may be accounted a cause of sea currents-a contributory cause of difference in gravity. The body of heat must he equal to the body of cold, otherwise the sea would grow hotter or colder, just as the body of rainfall must equal the body of evaporation, otherwise the sea would grow less or greater. Wherever the one

Difference in temperature cause of circuiation predominates it flows over and mingles with 
Swirls and rings of the sea.
Suirls of the air the other. In the process of exchange many circles are drawn in the sea, and currents vertical, horizontal, and "creeping," come into existence. The waters of the tropies are warmed, raised to the surface, set in motion by the winds, pushed poleward, and finally returned upon themselves in a completed ringa swirl of the sea. The waters at the poles are being chilled, sent down into the depths, passed on to the equator, raised up and set in motion poleward again-another ring, another swirl of the sea. Not here nor there, by the Atlantic or the Pacific, by continental shore or island archipelago is this exchange taking place, but all over, everywhere, continuously, unceasingly. It is a movement of the sea whereby its purity and vitality are maintained. Without it there would be stagnation and resultant destruction.

Not the currents of the sea alone but those of the atmosphere are set in motion by heat and cold. The scorched air lying along the equatorial waters, grown volatile and capricious, eddies around and around and finally forms into hot winds that rise and flow ont to the north and south, where they meet with colder winds coming down from the poles to take their place. They rise above the latter flowing pole- 
ward, become cooler, then descend and return to the equator as the cold air of the north or south. Again in these winds that parallel the ocean currents and, practically, are a part of them, there is a completed circle-a swirl of the air. And again is the very existenee of the air and its life-giving properties to the earth maintained by this movement. Without The lifegiving property of change. the exehange of aërial temperatures one part of the earth would freeze while another part would burn, and all parts wonld eventually perish from the violence of the extremes.

How different from this circulatory movement of our little world is the great elliptical swing of the solar system? Is there not a swirl of the universe as well as of the sea and air? And is it, too, not caused primarily by difference in temperature? The extremes of the equator and the poles are sufficient to set in motion thousands of miles of air and water; but what is the heat of the equator to the blaze solar system of the sun itself or the cold of the poles compared with the possible absolute zero of upper space? If the heat of the sun flows out (as we know it does) must not the cold of space flow in? On the tremendous eurrents thus set in motion would the planets of our solar sys- 
The Milky IV ay a Sargasso Sea.

The search for truth. tem be any more than tennis balls floating in the maelstrom?

Ours is but a single circle in space. For millions of years perhaps we have been eddying slowly in a Sargasso Sea, seeing on the other side of the pool Jupiter and Saturn and Neptune whirling around the rim. It is but a little swirl in the universe, but had we but the eyes to see and the mind to grasp we should perhaps find it not different in principle from the greater swirl. That vast clustering starbelt which we call the Milky Way heaps up from our horizon to a glittering ring in the heavens. What it circles no one knows, but there is little doubt that it is a circle. What power swung that mighty swirl into motion? Where blazes the luminary that drives those stars together? Are they themselves the central dynamos of the universe, and are all the constellations that plunge hither and yon through space driven off upon great ellipses by their stupendous heat?

There is no answer. The great truths were evidently not meant for us. We have never been able to understand them. We grope blindly for causes, dragging to light plausible theories that last a little time and then go their way, being wholly insufficient. The long argu- 
ment of science but proves its weakness. If the truth is ever known there will be no need of demonstration, for everything in human experience will immediately confirm it.

But we have waited long for the truth-bearer to come. 


\section{CHAPTER III}

\section{IN THE DEPTHS}

Superficial eifect of storms.
Shallowness of currenls.
The storms that sweep across the ocean plains-the storms that toss the ships and harry the coast and roar far inland through forests of pine and hemlock-have no more than a superficial cffect upon the deep sea. The rough winds irritate the face but do not penetrate far beneath the skin. The hurricane of the North Atlantic or the cyclone of the Indian Ocean may whip the surface into mist and foam, tear clouds of spray from the wavecrests, and, at times, darken the very sky with flying scud and rack; but, for lack of duration, never disturb the under-world of water, never so much as hint its presence to the great depths.

Even the far-reaching currents, with their Amazonian flow through the blue-green expanse, are waters that do not run deep. They move forward, they have great breadth, and they reach down much farther than any storm agitation because of their weight and their continuance; but possibly two hundred 48 
fathoms would be their limit. The Gulf Stream is supposed to have onward movement at that depth though there is no great accuracy about either the observation or the calculation. Its flow is, of course, more rapid in some places than in others, and its deepest depth would probably be obtained in such passes as the Straits of Florida, where it is forced through a narrow defile; but on the Banks, where it flattens and spreads, it must be much shallower. As for the depth of the smaller ocean currents, probably a hundred fathoms would be an approximate estimate. When such a figure is considered in connection with the average depth of the ocean (about two thousand fathoins), it will be readily seen that no ocean current more than seratches the surface of the great waters.

The tides that move about the world used to be considered of superficial penetration also; but it has been matter of surprise more than once to find by casual observation how deep they reach. From steep eliffs looking down through clear water the rush of a four-foot tide can be seen swaying the sea weed a hundred The depth of the

Currents merely srratch the surface. and fifty feet below; and in the harbors and inlets the impetus of such a tide is felt to the very bottom. 
Tides not perceptible in midocean.

Tille

theories.

Tidal waves.
In mid-ocean the tide is perhaps of less significance. On the surface it is not even noticed. The waters swell for six hours and contract for six more; but the open sea gives no indication of this and the ship we sail in has no perceptible rise or fall. Yet the tide comes and goes notwithstanding, and how deep its flood is not positively known. Who shall say that the great attraction of the moon pulls the surface of the waters out of the spherical but has no effect upon the depths? Does not the theorist of the tides believe that on the side farthest removed from the moon the earth is pulled away from the sea-away from the bottom of the sea? Oceanography is not by any means a complete science, and there are many facts, in the deep bosom of the ocean buried, that may some day arise to overset present theories.

As already said, the so-called tidal wave, set in motion by an earthquake or volcanic explosion, is quite different from the ordinary tide. The explosion that starts the wave may come from the bottom and may shake all the subterranean depths for hundreds of miles about it. The deep-sea fishes killed and blown to the surface by the bursting of Krakatoa would seem to indicate that the great wave set in motion by 
the explosion started from the lower depths. This wave moved across the Indian Ocean, possibly reaching down two thousand fathoms from top to bottom, swaying and tossing everything it encountered; until finally rounding the South Pole-half of the wave on either sideit met and destroyed itself. The South American tidal wave of $18 \% \%$, driven by an earthquake across the Pacific, may have bcen of The great tidal wares. even greater depth, if we may judge by its surface height. The jar that set it in motion must have affected the bottom as well as the lip of the dish.

Aside from these exceptional violences, which oceur only once or more in a century and last for only a few hours, the great depths of the ocean are doubtless very still, very motionless. None of the fret of the surface is felt in them; only the sluggish exchange of cold and warm currents that drag along the sea ooze or creep Stillness of ocean depth. inch by inch in vast fields from level to level. The lair of the great polyp is not invaded by wind or wave. Nor by sunlight. The fishes down there have eyes, but eyes perhaps not well fitted for our light. Phosphorescent beams, it is said, are all that ever come to them; but of that we may not be sure. If there were ears wherewith to hear in those ocean caves, they 
Darkness of the depths.

In the pit.

would be even less useful than eyes, save as a means of balaneing in aseents and descents; for

"There is no sound, no echo of sound, in the deserts of the deep,

On the great gray level plains of ooze where the shellburred cables creep."

Nothing there ever breaks the eternal silence or varies the vast monotony.

It is thought, again, that no vegetation of any kind lives in those depths, though this may be an error; and that no visible colors enliven its floors, though that, too, may be a false conclusion. There are no seasons, no springtime or harvest, no day or night. Time is as naught in this kingdom of the sea, where no king sits in state and no law is known but the law of self-preservation. And yet, hideous as it may seem, this deep, dark pit, without air or sky, where serpentine things creep and grapple and devour each other, should have its purpose in the economy of nature. Nothing is builded in vain. Out of the ooze and slime of the sea, who shall say what forms of life-repulsive stalk into nobler being!

But again the deadly chill of it! All the warmth of the sea lies on the surface. The 
underlying waters are cold-intensely cold. Not in the polar regions alone is this true, as might naturally be supposed. The waters there have given a temperature as low as $28^{\circ} \mathrm{F}$.; Intense cold of deep) water's. but the temperature underlying the equatorial waters is only a degree or more higher. Great wastes of ice-cold water underlie all the seas. The Pacific with its southern fields exposed to the sun might be thought warmer than the Atlantic, but in reality it is colder by about two degrees-the register being some $33^{\circ} \mathrm{F}$. for the one and $35^{\circ} \mathrm{F}$. for the other. Three thousand fathoms down the temperature of all the seas is practically the same.

What heat if any comes from the underlying earth to warm the great hollows of the sea can only be surmised. None is derived directly from the sun, because our sunlight is thought not to penetrate more than five hundred feet of water. And at the best water is not an easy medium to warm. The sun's rays pass through Water not easily u'armed. it, as through glass, leaving little heat behind. To be sure, the surface of the sea in places often takes a high temperature-the Red Sea, for instance, sometimes reaching $85^{\circ} \mathrm{F}$. or even $90^{\circ} \mathrm{F}$.; but it is only a very thin sheet of water that reaches that height. In the North Atlantic the sun may beat all day upon the flat 
Ocean temperatures.

The sea bods.

Mountains in the sea. sea and not raise its temperature more than half a degree. Moreover, the area of heatgathering water is too limited to affect the great body profoundly. Ninety per cent of the ocean waters fall below $40^{\circ} \mathrm{F}$. So, with all the warming and tempering effect of the sea upon certain climates or countries, it is still something of a cold blanket wrapped about the earth.

As for the sea beds themselves, one cannot think of them as other than the bottoms of wide valleys or great, flat basins lying far below us-sunken basins of the earth where the waters have lodged by force of gravital circumstance. The irregularities of the earth's surface foot up in actual height and depth a difference of some ten or a dozen miles. That is to say, if we consider sea level as the mean, we shall find mountains rising above it five or six miles and ocean troughs falling below it five or six miles. But there the resemblance seems to end, for there are no such abrupt mountains, valleys, or precipices in the sea as upon the land.

And yet there are exceptions to such a conclusion. The island group of the Bermudas is clearly a mountainous mass springing upward from the sea floor. The upper part of it 
is of coral formation and rests upon a huge tower of limestone somewhat like a capital upon a column. The soundings off the edge of the reefs give a depth of abont 2,400 fathoms, showing that here is a mighty butte, capped with coral, rising sheer through two and a half miles of water to the surface. St. Helena and Ascension Island, both of volcanic formation, also rise abruptly from great depths; and to the north of New Zealand there is a submerged basin from which lift marine sierras some thirty thousand feet without quite breaking the water line. But generally speaking there are few mountains in the sea other than those of coralline or volcanic origin. It e formations. is not probable that there are any extensire ranges or that there are great wrinkles or folds in the earth's crust underlying the depths. This is, of course, conjecture; and yet circumstances of dredging and sounding seem to confirm it.

The pot-holes that sink far below the average depth are just as rare as the elevations that rise to abrupt heights; but still they do exist in certain places. Off the shores, or "continental benches" as they are called, there are sometimes swift descents to almost fathomless depths-descents as orer the edge of cliffs and 
down walls of rock mile after mile. There is some such slashed chasm of the sea off the coast of Porto Rico where the soundings give a depth of $2 \%, 366$ feet, and there is a "trough" in the Pacific, a hundred miles off the Kurile Islands, where soundings show a depth of over five miles.

These hollows of the sea bed, as we have seen, suggest a correspondence to heights of the land; and yet it must be repeated that they should not be looked upon as inverted Hima-

Sea
troughs.

Sinks of ooze. layas. The sea trough is not exaetly hewn out of rock. It has no sharp edges; all its surfaces are worn smooth, not so much by erosion as by terrific pressure; and all its substances are honeycombed and softened by the action of carbonic-acid gas. The bottoms of the pit must be mere sinks of ooze. They cannot have the hard surfaces and sharp fractures of the eliff wall. The chemical action of the underlying water would make it quite impossible. Besides, the dredge keeps repeating the tale of ooze.

The shore beds, lying off the continents, are more varied than the depths. The cuttings of rivers, the rush of the tides into gulfs and bays, the pound of the breakers on the coast, help to create many irregularitics along the meeting place of land and sea. Then, 
too, the washings of the land, the admixture of silt and rock with the sea muds make a differShore beds and their ent bottom from that found in the deep-sea bottoms. troughs. And growing up from these sunlit bottoms are all forms of sea life and shore life. Along the continental benches are vast hillsides covered with algae as with an olive-green carpet, wide meadows where kelp slowly swings in the blue-green light, and out from the cliffs long slips and slides of rock (taluses leading downward into the sea), where float trailing green-and-opal ribbons, thin trunks and cylinders that stand like tiny sahuaros casting out living arms for food, and groves Along the shore benches. of dull green branches that have neither fruit nor foliage and never change hue nor place.

Impressive, indeed, to the sponge-gatherer and the pearl-diver are these gardens and forests of the shore that undulate only to the slow ebl and flow of tides; but they are merely the fringe to the mantle as compared with the barrens of the deep. Once tlie abrupt breaks of the shore-bench are passed the ocean bed shelves off into dark shoals that correspond to elevated Dark trenches. tablelands, and are followed by depths that lie flat like inland basins. These latter are cut through by long trenches, not very different from the deep arroyos of the desert or the 
Haunts of the oetopus.

Make-up of the sea muds.

Terrigenous deposits. watersheds of mighty rivers. For hundreds and hundreds of miles, under an average depth of twelve thousand feet, stretch these basins of the sea, rolling basins with rounded surfaces that have no outeroppings of rock in peak or precipice-mere wastes of soft mud. It is not possible to imagine anything more drear than these cold phosphorescent haunts of the octopus, reaching seaward with unending monotony.

When closely examined under a glass the make-up of the sea floor is not found to be of one kind of mud alone. The dredgings of the Challenger, the Blake, and other ships, reveal a large variety of deposits; and these have admitted of some scientific classification. The shallow-water deposits, as already noted, are of finer gravels and sands washed down from the continental shelves and carried out to sea by vagrant shore currents. The nature of the coast usually suggests the quality of the deposits lying off it-a granite coast with much iron in it producing the typical red sands, coral islands producing coral sands, and volcanic reefs casting down volcanic débris. The beds of semi-enclosed waters, such as the seas of China and Japan, or such vast inlets as the Baltic or the Black Sea, are made up of similar "terrigenous deposits," as they are called. 
There are other ways whereby land deposits get into the sca beds - other ways than by washing down from the shores. From the poles, reaching toward the temperate zones, there are vast plains or "banks," composed of fine detritus which was originally carried seaward by Glacial glacicrs and icebergs; and, as the bergs melted, gradually sank through the water to the bottom, forming there a glacial ooze. Again the basin of the Mediterranean, along the African coast, has been changed in no small degree by the sands of Sahara caught up in the air by southern siroccos and scattered far and wide upon the waters. And, again, there is no doubt that such volcanic eruptions as the recent one upon the island of Martinique, with its clouds of dust and ashes, have a decided effect upon Volcanic dust. the adjacent sea floors.

But the deep-sea beds, containing what are called the "abysmal deposits," are not influenced by shore or land changes. In five hundred fathoms of water, and far removed from land, nincty per cent of the sea floor may be made up of the cmpty shells of foraminifera, pteropods, and other organisms that live in and upon the surface of the water. After the death of the occupants these infinitesimal shells sink slowly through the dark waters to the occan's 
Pteropod ooze.

Globigerina and Radiolarian ooze8.
The Red Clay. bed where, with many millions of others, they help form a "Pteropod ooze." At a depth of, say, two thousand fathoms the same shells of foraminifera are forever raining downward from the surface; but the bottom deposit does not show more than an average of sixty per cent of them. When three thousand fathoms of depth is reached the foraminifera are reduced to thirty per cent. This decrease is owing to the increased presence of carbonic-acid gas, which, as already suggested, dissolves and destroys the shells. The remainder looks like a gray or blue chalk, is called "Globigerina ooze," and is found chiefly in the North Atlantic and Southern oceans. Finally this, too, disappears giving place to a "Radiolarian ooze," composed of the skeletons of radiolaria or star-shaped organisms less susceptible to the influence of carbonic-acid gas than the foraminifera. In the greatest depths of all is found the Red Clay or Red Mud deposits.

The Red Clay which corers the deep floors of the Pacific and the Indian oceans is made up of refuse and residue-that which can withstand the strong chemical action of the gases. In it may be found decomposed volcanic rock, pumice, zeolitic crystals, manganese oxides, meteoric iron, teeth of sharks, and ear bones 
of whales. Few, if any, shore deposits are apparent in it. The rock is vitreous refuse belched forth by subterranean or insular volcanoes. The minerals are supposed to be of cosmic origin-planetary dust and meteoric fragments that have fallen into the sea and become disintegrated. The great quantity of sharks' teeth remains quite unaccounted forat least their apparent gathering together in these ocean basins is considered very strange.

Another thing that seems quite inexplicable is that no deep-sea dredge, no rope of steel, has ever drawn up anything from the Red Clay beds that tells of humanity. In shallow waters it may well be there lie

"A thousand men that fishes gnaw'd upon;

Wedges of gold, great anchors, heaps of pearl, Inestimable stones, invalued jewels,

All scattered in the bottom of the sea."

Without doubt there are whitened bones, and ship-girders of iron, and great guns of steel, lying down below the lost fields of battle or of tempest; but not in the great depths have any such relies been found. The sunken basins give no hint of man or his doings. Perhaps his years of navigation have been too few. The Red Clay floor is one of very slow accumulation and is

Nothing of humanity in the great depths.

Contents of the sca pits. 
The deepsea record not complete.

Ocean transparency.

Seeing with the unaided eyc. supposed to be very old. Then, again, the deepsea record is by no means complete. It is largely the tale of the Challenger dredge. That was a beginning not a finality.

And, of course, there is no seeing into the great depths, no gaining of ocular proof. If the water were clear-yes; but it is not. The particles of dust, salt, and minute sea life that float in it check and bend back the rays of light, at least the rays familiar to us in the sun's spectrum; and what we see and know of ocean transparency is merely the illuminated surface, a hundred fathoms of the upper crystal.

It is said that in the clear waters of the polar regions the unaided eye can see seventy fathoms down-a statement that seems very questionable and yet may be true, though certain experiments, made by sinking white disks in the water and noting the point of their disappearance, have not resulted so favorably. All depends necessarily upon the clarity of the water. That at the poles seems a trifle clearer than that at the tropics. And yet it is astonishing what depths may be sounded with the eyc in such a salt sea as the Mediterranean. Looking down into it from the prow of a yacht, the beams of the sun can be seen, hun- 
dreds of feet below, scattering like golden threads through the under-waters, lighting up great beds of kelp and banks of sponges and The clent gray floors of ooze, where flounders lie flattened Mediterin the mud and polyps creep and albicores go gliding by with apparently no effort.

Even more marked than the Mediterranean is the crystalline quality of the Caribbean. So clear is it that Columbus-Columbus who was seeking a new trade route rather than a new beauty of the sea-could not help commenting upon it. The Gulf of California, on the $\mathrm{Pa}$ cific side, is quite as clear. From the high cliffs near Guaymas one can see floors of white rock, two hundred feet beneath the surface, which are not only distinctly visible to the eye The Caribbean and the Pacific. but cast reflected lights upward that affect the color of the surface waters. The patches on the surface that look light gray or yellow or perhaps blackish-the patches that the navigator so quickly notices and associates with recfs or bars-are frequently caused by the reflection of the underlying sea beds. They are proof in themselves of the transparency of the water.

But the underlying sea beds may also destroy transparency. The muddy bottoms of the North Sea make its waters cloudy, yellowish,-

Bottom reflections 
Muddy bottoms and their effects.

Mineral stains.

Sea sawdust. at times so turbid that a few feet may obscure all vision; the Yellow Sea is yellow largely because of its muds held in solution; and in other seas and bays vegetable deposits produce different hues of red, brown, or gray. There is little doubt also that minerals may make local colors in the sea as in the smaller fresh-water pools of the land. The stain of iron has given the water along many a rocky shore a saffron hue, and the small streaks of bright blue-green that oceasionally show in shallow bays may possibly be caused by some vein of copper underlying them.

Aside from such local happenings, aside from patches of "sea sawdust" (beds of floating cylinder-shaped alga of minute proportions, or swarms of one-celled animaleulæ that give the sea distinct hues of red, brown, or whitc), there are heights and depths of sea color that extend in body over vast areas. The sca is not an unbroken blue. That there is varicty no one ean doubt who has seen the Gulf Stream flowing in a dark eurrent through the lighter colored body of the Atlantie. The contrast is too apparent. The ultramarine eurrent changes under different skies; but no matter what the sky, the Gulf Stream is always a darker and a different hue from its 
bordering waters. This intimates that the water itself has some property or quality peculiarly its own which gives it local coloring. What is this property?

Particles floating in water have, no doubt, The Gulf Stream the power of producing a color effect upon the coloring. water itself. The fine hue of the Rhone is caused by the granite and mica grains that it bears with it to the sea, and for many years this river was supposed to lend its coloring to the Mediterranean and make that sea blue. But the Mediterranean has other particles in its water's that are equally efficacious in producing color. The chief of these is salt. The salt particle, because of its minuteness and its affinity as regards size, has the faculty of interrupting, checking, refracting, reflecting, the small blue ray of the sunbeam. It does this so effectively that, when seen in great mass, the particles apparently reflect from the sea depths a color not unlike the blue sky itself. It is then that we behold "the deep blue sea." That the sunlight and blue sky are contributory particle. causes of the blue sea we may be sure, for the blue largely disappears with the sun and sky. The bluest of seas when under storm elouds with wind will show gray-green in every curling wave; and wherever the wave breaks on the 
Effect of blue sky.

Lncal color of sea vater is green.

Salinity and its effect. coast or on the ship's side, there will be rushing crests of green-and-white foam. This is equally true of the Gulf Stream, which beats up into a deep green in storm for all the indigo of it under sunlight.

It would seem then that while the sun-andsky color of sea water is blue. its local color as seen under neutral light is pale green or gray-green. Many minor illustrations rise up readily enough to confirm such a belief. The stories told by the sponge-fishers and pearldivers are all of green water below the surface; at Venice the reflection of the gondola in the canals is not blue or black but green; and sailing into the Bay of Naples on a clear day, the water appears intensely blue while the same water seen in the tanks of the Naples Aquarium is green.

Possibly the salt particle is responsible for the great bulk of local sea coloring. It gives us blue when the light is reflected, green when it is transmitted, grays, purples, and mauves when it is broken. The salt particle-salinity -also gives body and quality to the color. The waters of the polar regions, continually freshened by snow and ice, are much lighter in hue than those under the equatorial sun, rendered densely saline by the unceasing evaporation of 
the fresh element in them. And, of course, much apparent body is imparted to sea coloring by the depth of the waters. When taken up in an ordinary glass salt water is apparently colorless. There is not enough of it to make a tint. Air at short range is just as negative, but when seen several miles in depth the color of the element is very noticeable.

The sea water is not so subtile, not so delicate, in hue as the air. No one can guess how many strata of atmosphere we look through to gain the blue sky over, say, Mexico. A hundred miles away we ean see the blurred forms of the Mexican sierras melting into air, and feel the blue haze in between; but it has no such intensity as the blue orerhead. The sea water is infinitely denser. And yet looking down into it who ean say where the eoloring begins or where it ends! It is no surface veneer. It gains by depth, and is wonderfully beautiful beeause of its transparency and luminosity. The color increases with the layers of water, deepening and darkening from the bluegreen of turquoise to the darker hue of amethyst and the deep blue of lapis-lazuli.

And still there may be a further cause for

sea coloring that I am tempted to suggest at least. The deepest hues are to be found at

Coloring by depth of water.

Color of water and air. 
Temperature as a color factor.

Color, local and reflected the warm tropics; the lightest at the cold poles. Temperature as well as saline density may have something to do with producing this result. It is a noteworthy fact that the bluest pools in the Yellowstone Park are the ones with hot water in them; and certainly in the ocean the bluest waters are those that have a surface temperature running as high as $80^{\circ} \mathrm{F}$. or more. Probably no one of these factors-temperature, depth, or salinity-is sufficient in itself to account for sea color. It is more likely that a combination of them all, with perhaps other causes unknown to us, are necessary to the production of the different results.

So much for the actual color of the sea, which varied as it may be, intensely beautiful as it is in quality, more wonderful than precious jewels in transparency and light, is still but a dull beauty compared with the exhaustless splendor of the surface reflection. The Great Mirror which mingles with its own coloring every color in the gorgeous furnishing of the sun and sky, tempering, blending, harmonizing all tints into supreme glory, is not to be equaled by any other beauty of the round world. It has no limitations, no fixed repertory, no "usual appearance." All things of color and light belong to it, every flash from its 
myriad facets is a new revelation, every color on its shimmering surface is a new combination; and not one of the millions of wares that heave along its surface bears likeness to another. The variety of the sea surface is infinite. 


\title{
CHAPTER IV
}

\section{THE GREAT MIRROR}

\begin{abstract}
OचT of Judæa, seated back from the coast on its Syrian hills, - Judæa that had more fear than knowledge of the great waters-came the earliest suggestion of the sea in art. This was nothing more nor less than a huge round reservoir of brass that occupied a place in the courtyard of Solomon's Temple at Jerusalem. It was fifteen feet in width, a hand's breadth in thickness, weighed over twenty tons, and held nearly five thousand gallons of water. The backs of twelve brazen oxen supported it, the sides of it werc of beaten design, and its lip was wronght, as the Hebrew Seriptures tell us, like " the brim of a cup with flowers of lilies." The name given to it, and by which it was usually known, was "The Sea"-sometimes "The Brazen Sea."

What representative character was expressed in this massive basin, what if any likeness it was supposed to have to the actual sea, we shall not now know. Perhaps it was called the sea because of its great water-holding capacity and


probably there was no significance attached to the fact that it was round. And yet that roundness is an apparent truth of the real sea. As we stand upon the deck of a vessel in midocean we find ourselves in the exact center of an enormous circle and the horizon line is the bounding rim. We know that this is merely an illusion, that the sea reaches on three thousand miles to France or eight thousand miles to Japan, as the ship sails, that there is no disk of water, and that the appearance is misleading; yet in the presence of the sea itself the circle. we are almost persuaded to believe our eyes. The great expanse seems circular though it has no such form.

And we think it lies flat though it curves down and away from us, following the rotundity of the globe. Indeed, it often has a very opposite look. Instead of slipping down and away at the horizon it secms to rise up. That the lip of Solomon's brazen reservoir was fashioned to represent the sea horizon is perhaps a far-fetehed fancy; but that the sea The "riseup" of horizon horizon itself looks like "the brim of a cup" rim.

will hardly be questioned. It apparently lifts against the sky line, seems to draw in at times, and is often as smooth, as clean cut, and as sharp in line as any lip of porcelain or brass. 
The resemblance to a shallow bowl is not to

Bouls of blue.

Illusions of the sea.

A limitless space.

be shaken off. It grows upon one and becomes more impressive as we study the blue above us. For there in the sky is another, an inverted bowl of blue, that comes down and fits upon the bowl of the sea. The horizon line is the point of juncture, and the brims meet so exactly that no ray of light creeps through to tell us what lies beyond.

It seems, then, by a slight stretch of the imagination, that when at sea we are in the center of a hollow globe formed by two hemispheres of blue. We are shut in and yet feel no sense of confinement or of oppression. The elements of sky and sea are too transparent, too fugitive, too intangible for that. Moreover, we are continually moving our central base as the ship moves, wandering through a region that knows no limits, has no beginning, comes to no ending. As for the world of land, it is possible for the moment to forget there ever was such a thing. We are creatures of the more volatile elements; and if along the western verge dimly show the silver and gray spots of some eoral group, they are but as

"Summer isles of Eden lying in dark-purple spheres of sea";

and if overhead the white clouds go by in flocks, 
they are but as vague forms of light that slowly glide under the eelestial blue.

The two blues! Have they always been blue to human eyes? The Semite thought the sky was merely a shade of white, an embodiment The two blues. of light akin to sapphire; and the Greek spoke of the sea as "wine-dark" and even "black," but never "blue." The Rig-Veda, the Talmud, the Homerie poems, the Edda, do not mention the word. Was this a limitation of vision or merely of voeabulary? The average person today has neither eye nor name for the finely broken hues used in the manufacture of silks and tapestries, and it is not to be wondered at if the ancients confused colors with the light which they contained, and considered them merely as tones or shades of white.

Tet the blues have a very real existence. The sky color I have already described and explained as eaused by the dust particles in the upper air which refract and practically hold in cheek the blue rays of the sunbeam;* and the sea eolor is always more or less a reflection of the sky. The sea itself is like a mirror and, of course, it comes the nearest to faithfully reproducing what is over it when its waters are the smoothest; but from the fact

The sen litie a mirrur.
Knouledge of eolor with the ancients. 
The image in the sea is darker than the original.

Darkened reflection at horizon. that it has a color of its own-a local colorit is not precisely like a mirror of white glass with a quicksilver background to catch and throw back the reflection. It is more like the refleeting surface of an aquamarine or the facet of a sapphire and puts some of its own hue in the reproduced image. The image in the sea therefore is always a shade or so darker than the original in the sky. The cerulean blue above becomes an ultramarine below, a white cloud becomes a gray cloud, and a gray cloud a dark sooty cloud. Sunset hues blend into new tones and mingle into deeper harmonies, and light itself, whether from sun, moon, or stars, becomes more mellow in tone, if less brilliant in intensity, when seen in the mirror of the deep.

This darkening of the reflection seems more marked along the horizon line than elsewhere, because the sky near there is often whitish in tone-much whiter than the sky of the zenith -and thus makes more of a contrast; but everywhere and anywhere the reflection is darker than the original. This becomes still more noticeable as soon as the surface of the sea is ruffled by wind. The many facets of the littlc waves immediately give out reflections of their own, like pieces of a broken inirror. As they 
pitch at odd angles the dark spots upon the under portions or sides of them which emphasize their form and drawing, look like shadows; but such they are not. They are the side reflections of neighboring waves or, more often, wave-facets practically out of reflection -ware-facets showing merely the color of sea water. A rery faint shadow is sometimes seen under the crest of a breaker as it curls, curves, and pitches forward to a fall, especially if the water be muddy; but a shadow on the open sea, cast by its own waves, is really non-existent.

This darkening of the reflection, this shading of the mirror into a deeper hue by reason of a ruffled surface, is very noticeable from the dunes or cliffs looking seaward on a breezy day. Not only is the whole sea darker than the sky, in ruffled seas. but, wherever the gusts and flaws of wind can be traced, patches of color will appear still darker than the surrounding water. Frequently these patches of broken surface show extraordinary tints owing to eccentricities of light. It is an everyday experience at sea to find the water on one side of the ship looking Eccentricities of light and color. toward the horizon perhaps a deep blue, and on the other side perhaps a pea-green. Again, the light produces a different appearance as we turn toward the sun or away from it. A road-

Shadous on water. 
Sen under cloud light.

Reficrtions in shodowed spuces.

way on the land, if we follow along it toward the setting sun, is apparently darker than the same roadway going to the east. A similar effect is noticeable at sea, for looking westward at sunset we see into the darkened portions of the waves, and looking eastward we see their reflected high lights.

More extraordinary still are the hues that creep into ruffled seas when the blue sky is broken by cumulus clouds, or mantled by veils of the stratus and nimbus. Almost any unthinkable and unbelievable color may then appear, cheeking, streaking, marking the sea with strange patterns in odd contrasts. The ordinary white cloud which travels slowly across the sky will, if the sea is smooth, cast an ivory reflection; if the sea is rough, it may, in place of reflection, cast what is practically a shadow. This shadow (or as Ruskin prefers to call it, this reflcetion in a shadowed space) is usually lilac-blue-darker blue than the surrounding water-and within the shadow the little faceted waves as they dance often shimmer like triangles of blue glass. Again, the gray clouds of the nimbus, that shut out the heavens entirely, cover the whole sea area with a dull lead color; but when through this veil of clouds a sun shaft breaks and strikes upon the water, 
you are perliaps surprised to see that spot of water show a local color of lively green, its little facets flashing like emeralds.

Whether the surface is smooth or rough, the sea is eertain to take its light and most of its coloring from the sky overhead. Clouds of rose and lilac that spread around the circle of the horizon at dusk and reach up into the zenith will produce the amethystine sea, which is not by any means an uncommon appearance; and "the purple seas," that poets delight to talk about, are realities under cold storm clouds. In the same way the sea of gold and the wave of fire come from the chrome yellows and searlets of the sunset west; and out of the same resourceful sky come broken tones that, seen in the mirror, tell a tale of silver, of steel-blue, of pearl-gray, of opal, of turquoise, of robin's-egg blue.

But the reflection is very much deadened and often obliterated if the water is lacking in purity. The North Sea, for instance, after a storm has raged for several days and stirred up the yellow muds of the bottom, will not show blue notwithstanding the bluest of skies may beam above it. On such a sea dazzling white clouds make only dull yellow spots, the reds of sunset merely deepen and render more

Sunset skies in the water. 
Lffect of temperature on color.

Color in polar reaions.

opaque the local coloring; and as for the pearl and opal tints they are practically lost. Oftentimes at sunset or sunrise a muddy sea will flash light like a diamond and yet completely fail to flash color.

The quality of coloring both in the original and in the reflection is also greatly influenced by the density of the atmosphere and by temperature. The clear white light of the polar regions favors sharp colors, which instead of blending together hold aloof and keep their individuality. There the aërial envelope does not bind all hres in a golden thrall, but allows the blues and reds and greens to glow intense. In the morning and evening, when the sun's rays strike the sea obliquely, there are long trailing tracks of sunlight-sometimes yellow and sometimes red-twisting and writhing on the uneasy waters. As for the twilight reflections in the water, they are vivid in reds that are all scarlet, as the moonlights and midnights are weird in blues that are all purple.

But the thin polar air, with its consequent white light, is not farorable to the most perfect color harmony. It is too crude, too limited in its scale. On the contrary, sunlight falling through a heated atmosphere seems to be shivered into very delicate colors that blend 
again, at different intensities, into pronounced tones. Thus on warm summer days, in tropical regions, the air over the sea at sunrise will be pale blue; at noon, if the heat continues, it will show a trembling dancing gas-blue; and by three of the afternoon perhaps it is rosy blue or opalescent-something that shimmers and changes like mother-of-pearl.

Given such an atmosphere above a smooth water surface and the inevitable result is that supreme beanty of reflection-the opal sea. The sea not only reflects the air, but its very surface seems to be changed by it into an opalescent transparency; just as the sky orerhead The opal is modified by it into something that looks like blue seen through opalescent glasses. Other atmospheres, more or less color-laden, that lie above the sea are as clearly reflected but perhaps not as readily noticed. The silver gray that comes with mist or fog is so common that we hardly see its effect at all; and the deep purple that comes with twilight-so deep that you ean see it, looking out the darkening cirele of the ship's cabin windows, as a block of indigo-is again overlooked because of its frequeney. But the gas-blue which comes with great heat puts a very remarkable face upon the sea, and the opalescence is so splendidly ples. 
The Mediterranean in the hea: of summer.

The Dalmatian. const. pearl-like in its quality that it cannot fail of attention.

Yet the opal sea is a common enough appearance during hot weather. It shows slightly different tints on different days, and perhaps only in the still waters of inland seas like the Mediterranean or the Caribbean is it seen in its full splendor. And just here I can do no better by way of describing this and other appearances of the flat sea than by giving extracts from my note books. The notes were made at different times, by different seas, and may sound contradictory or inconsistent, and yet they are quite true to the time and place. For the sea is not any one thing but many things, and rarely repeats the identical appearance.

"July 3. Noon. Along the Dalmatian coast, steaming slowly through the island groups below Zara, the day fair, warm, and hazy with a peculiar milky-blue haze. The sky is blue suffused with rose; the smooth water, where it reflects the sky, is pearl-like; seen looking straight down into it from the shadowed side of the little steamer it is green; under the shadow of white clouds it shows blue; and under the shadow of the smoke trailing aft it shows reddish-brown-deepening and darkening where the water is most broken by the propeller. The bare Velebit Mountains, gleaming white as chalk in the sunlight, are seen reversed in the sea and the whiteness of them is reduced to an ivory tint of great beauty.

"Evening. The sea ruffled up this afternoon under 
a hot wind, the reflection of the steamer smoke on the broken water became a very dark cobalt, and the sea itself, breaking over white reefs and shelving rocks, showed a vivid aquamarine. The sun has just gone down in a blaze of fire that licked the tops of all the waves into flame. In portions, where the surface is comparatively smooth, the yellow of the sky makes a golden floor of the sea. The edges of the shore show ultramarine, and just out of the line of sun-fire the sea looks like blue ink. This is the coloring of 'Turner's 'Ulysses and Polyphemus' which I have always thought something of an impossibility in its hue and tone, something done by Turner for artistic effect, regardless of truth. I do not know now that Turner put in his cold gouts of blue against his hot golds because it was true. He wanted the contrast-the relief of the warm and cold colors-to make a picture; and Turner was a pieture maker rather than a nature or a truth lover. But here is his effeet in nature, nevertheless."

A few days later at Ragusa, with the same sea and the same weather, a slightly different appearance was noted.

"The day is hot, clear save for heap clouds over Monte Sergio, the air rosy, opalescent, swaying, wavering. The town, with its great walls and round towers, its domes and turrets, lies below me, yellow with the glean of limestone and stained marble, reddish with tile roofs that show everywhere, and almost girdled by the deep blue sea. The white road from Gravosa is gay with the gleam of villas seen in between groups of tall palms, Ravenna pines, mulberry and sycamore trees. Dotted here and there are The toun of

The 1 driatic at sunset near Spalato.

Turner pictures in nature.

Ragusi. 
Seen from Monte Sergio.

The wonderful sea. patches of poppies, beds of cannæ, great masses of oleander. At the southern end of the city is a little harbor where fishing smacks with gray, yellow, and red sails are slowly gliding about, a lead-colored torpedo boat lies at anchor, and from the stern droops the Austrian flag, showing a blood-red reflection in the water. Along the wharves are reddish groups of Albanians, Bosnians, Herzegovinians. Rings of chimney swallows and white pigeons go circling around the towers; and between the harbor and an outlying island drifts of gulls slowly wing their way with white backs gleaming in the sun. Far out at sea a black ocean steamer is trailing a sooty line of smoke along the horizon. Around me on the mountainside are worn-out groves of olive, and above me are thistle and cactus patches where donkeys and black goats browse, and where a stony trail winds over the mountain and into the neighboring valley. Bands of Herzegovinian men and women in their picturesque costumes are coming and going to market along the trail. They stop, pass the time of day with me, and I tell them in Italian, which they do not understand, that the sea is beautiful; and they answer, in some dialect which I do not understand, that it is most beautiful. Our languages do not convey much, but we comprehend, nevertheless. We are talking about the wonderful sea, and they are not so weary with the everyday sight of it that they fail to respond. Is it always so beautiful? Yes; the land may yield little foorl and the sun in summer is perhaps burning hot; but always there is the peace and beauty of the sea stretched bcfore them. Has the sun ever shone upon another such sea as this? As I watch it to-day from the hillside above this ancient city on its foot of rock, it seems as 
though it could never have its equal elsewhere. But it is the old story. Drifting along this strange coast, on this wonderful sea, each day reveals some new beauty more lovely than the last."

Opalescence, when it gets into the air, seems to fight all shadows and turn everything into some tint or hue.

"July 7. In the Gulf of Corinth. The day just breaking. The sea is like glass. Thin clouds lying along the eastern horizon like a barrier. Above them great loopholes of blood-red sky, high up toward the zenith a shading of rose, and in the west a dark purple, star-lit veiling. The sea responds sluggishly to the The sea in the early splendor from above but warms in coloring as the white light of the moon and stars goes out before the coming day.

"Noon. The sea is a little ruffled, shorving about the steamer's sides a wonderful blue-almost as intense as that at Corfu or Capri. Far out it makes a dark cobalt mass, and along the rocky shores it glows green, a Nile green. A haze is in the air through which the hills show rosy and pink. Far back from the North coast looms Mount Parnassus-a vision of heliotrope lost in a lilac haze. It is wonderful just now, not because of its classical associations, but as a mere rock reflecting the most lovely light and color in the world. The old masters, Leonardo, Giorgione, Rembrandt, all their lives pursued the mystery of shadow; and even Whistler the modern (who does not, however, belong in the same class) made some noise in the world with 'nocturnes' and twilight shadows along the Thames; The opalescent air.

The heliotrope of Mouni Parnassus. but here over Mount Parnassus is the mystery of light, 
In the

Cyclades.

Sapphire water. light shattered into heliotrope hues without a suspicion of dark shadow. Where is the master, old or young, who has painted it? Claude Monet has attempted it and been laughed at for his pains-more's the pity!"

During great heat the fiery colors of the opal seem to come forward and (especially at sunset) to accent and even dominate the color scheme of the waters.

"July 14. Steaming through the Cyclades. The day is reeking hot, with a blue sky and small heap clouds that seem to have a pink flush about them. The air is opalescent and radiant but not a breath of wind. The sea, sky, and air are all married to-day-all blended into one rosy blue glow. Even the heliotrope hills on the little islands come into the harmony. I have never seen such a wonderful reflection of the air from the sea. It is much stronger than the mirage on the desert which produces the illusion of water by reflecting the sky from the strata of heated air lying along the ground. Yet the water when out of the angle of reflection (as at the bow of the steamer looking down) is blue, almost sapphireblue, and so oily-smooth that the white foam thrown out by the cut-water rolls over upon the blue in patterns that suggest white lace. Amidships the steamer makes a swelling wave, but the surface does not break nor does the blue show. The swell is opaline and is curved like the edges of the mosaic arches in San Marco at Venice. Opaline, indeed, is the only word that approximates the description of the color. At times it is golden and rosy, then milky blue, reminding one of absinthe mixed with water, and then again pearl-like. Last night at sunset the color of the sea ran into the high notes of the 
opal, became glowing and fiery, and finally died away in a dream of blue and silver."

The opalescent sea is not an appearance that belongs solely to the tropics, but is seen as far north and south as the arctic circles. OccaThe opal sea seen in manylatisionally the northern and western coasts of Scotland show it with a sharpness of color that might better be called iridescent; and the Atlantic coast about Labrador and Nova Scotia have it mingled with breaking fog and summer mist in a tone that might better be called silvery. At Bar Harbor, on Long Island Sound, off the Florida Coast-anywhere by the Atlantic seaboard where bays or inlets give a chance for smooth surfaces-the opal color appears, often accompanied by a slight mist and a white horizon.

And frequently in times and places where one would expect only opalescence-in tropical seas like the Southern Atlantic or the Pacific during the heat of early summer-one will find cool colorings that might belong to the Behring Sea or the Iceland coast. In my note book of May, 1900, I find the following memorandum about the waters of the Pacific lying above Mazatlan in Mexico:

"Hot morning with no wind, lowering clouds, and a lilac sky in the east which has been deepening into pur- 
Cold colors in the tropics.

The quality of light.

Different tures. ple ever since daylight. The sea, too, is purple, and growing more so with the darkening of the light. The water is perfectly flat, and the indefinite clouds are mirrored below, but with a deeper tone than in the originals. The shore and hills are purplish also, the air is mauve color; the very light seems to be tinged with this hue as though the only rays of the sun that got through the clouds were blues and violets. There is a lilac envelope about earth and sea and sky. Such an effect if reproduced in painting would hardly meet with acceptance. People would insist that it 'isn't true to nature' -meaning, of course, that the only truth is the most obvious truth."

The quality of light-that is light as modified by atmosphere and temperature-is responsible for all these beautiful tones of color in the sea, sky, and air. There are days when it spreads a purple chill, when the clouds are purple and the air is cold blue, and the water a mixture of them all. Then there are other days quite the opposite of this when a rosy hue is filtered through the thin filmsheets of the stratus and a flush of rose is in the air and on the sea. And, again, there are other days when the Indian summer of the woodlands scems to be upon the waters and the hue is golden blue or even yellow. More frequently, of course, is the familiar silver tone that aceompanies a slight mist or lifting fog, 
the pewter tone that comes with a dull day, or the cold gray tone that follows rain.

The striking effects of light and color at sea are usually at dawn and twilight, but it is not often that these equal in brilliancy similar displays along shore. It requires apparently much dust in the atmosphere to make very bright coloring and the sea has less of it than the land. However, brilliant sky-effeets do appear at sea.

The dawn light at sea. The dawn is usually cool gray, pale yellow, or possibly in summer months rose-tinged, or lilac. The light spreads up toward the zenith and around the horizon ring showing in the sky with apparently greater ease than upon the sea. That is to say, the envelope of air which we eall the sky must be lighted before the sea, which is but its reflection, can respond. At times the water seems to lie cold and inert, giving back indifferently the light and color from above; but as soon as the sun rides up Spread of the light. from the ocean's rim and the direct rays strike the surface, there is a change. The wide sea is instantly flooded with light; not the pictorial compromise in yellow paint of Claude and Turner, but the pure white light of the sun, scintillant, penetrant, above all things luminous.

Oh, the radiance of summer mornings at sea when the ship goes driving straight into 
Radiance of early morning.

I. ight on ruffed seas.

Coloring of sea at midday.

the dawn and the light keeps springing up above the horizon, above the clouds, above the yard-arms of the foremast! How wonderful the spread and reach of that radiance, how subtle its reflection in the long rolling sea! Its coloring is usually no richer than pale hues of lilac, rose, or saffron, and over these there is generally cast a dominant mantle of silver. As the sun lifts high in the heavens the silver is the coloring that finally rules. The narrow pathway of light that comes to us along the sea is dazzling in its brightness, and if there is a broken surface it will glitter as though made up of countless diamonds. By ten o'clock with a ruffled sea the sun's rays are to be seen hitting the little facets of the waves with shots of light that seem to strike out, not fire, but light again; and by noon the pathway has disappeared and the light itself has become less apparent because more widely diffused.

The coloring of midday on the sea is usually not observed because the hues are all low in key and some of them are bleached; but as the afternoon wears on the light becomes more mellow, the color warmer, the reflection sharper, until at sunset perhaps the west is all afire with glowing hues that wax and wane, shift and change place, then reappear in tints 
more lovely as they faint and fade. Nothing in painting can more than suggest such a color scheme as this. Turner's most brilliant pigments are dull as ditch-water beside the flaming sea; and Claude Monet's primary colors, placed in juxtaposition upon the canvas for an effect of light, do not reach halfway up the scale. No pigment ground in a mortar or squeezed out of a lead tube ever eame within fifty degrees of nature's hues.

Almost invariably at sea we watch the sunset in the sky rather than in the water, and yet the reflection below is perhaps more beautiful beeause more harmonious. The colors deepen and become finer in quality. The scarlets run into dark red, the yellows into orange, the blues into ultramarine. The water becomes a medium, an atmosphere that blends all the hues together to make a color mystery as profound as any held in the ocean's depths.

And yet still more distinguished in color than this sunset sea incarnadined are the waters back in the east that reflect the opalescence of the sky in hues of mother-of-pearl. The eastward-lying sea at sunset never startles nor amazes; it is not noisy nor blatant, but it has the charm of perfect aecord and the subtlety of refined beauty. You watch it for many min-

Insufficiency of

painter 8
pigments.

Sunset colors in the water.

Ersturardlying waters al sunset. 
utes seeing new tones and lights emerge and shift, change and disappear; and in its death throes-when it slowly fades before the night shadow creeping up the eastern sky, when the lilaes of the horizon turn pale gray and the azure of the sky becomes a cobalt-it is still beautiful as a shield of blue-steel lying there in the twilight.

Moonlight on the sea.

The Angelus hour.
Perhaps at this very time and before the twilight has passed, the oval-shaped moon comes up over the eastern sea, lighting the sky anew with silvery opalescence, and mingling its soft luster with the fading glory of the west. The light now comes from two sourees and both of them pale reflections of the sun itself. How supremely beautiful it is in its soft glow, how wonderful in the coloring it creates-this most poetic light ever seen on land or sea! And how impressive it makes the Angelus hour-the hour of prayer when the tired world bends the knee and rests a moment lost in the beauty of the upper sky!

"Ave Maria! O'er the earth and sea That heavenliest hour of Heaven is worthiest thee."

How many hearts have overflowed in utterance, how many vows have been made, how many faiths have been pledged, under the spell of 
that hour of love! And the beads that have been told, the cries for strength and help that have gone up, the tears of repeutance and despair that have fallen in that hour of prayer!

Man is, after all, an emotional animal. He is easily brought to his knees. And it may be a very slight thing that brings him there. The scent of meadow grass, the wild rose by the roadside, the moan of the autumn wind, the Effect on the emotions of the Angelus light. falling rain-any one of them may be sufficient. But above all nature's manifestations whereby we are moved emotionally must be placed the twilight sea. The still water at evening with the Angelus light upon it is something that foolish people may pooh-pooh in public, as children in the dark whistle to keep their courage up; but deep down in their hearts they have an emotion about it-a feeling for its beauty and a love for its tranquil splendor, if nothing more.

And after twilight has gone and the moon alone is weaving a pathway across the water, when the little silver-rimmed waves are gently lapping on the beach and the tall pines on the headland are standing motionless against the The Angels Pathway. purple sky, what fancies come and go across the sea! Memories, associations, aspirations, regrets, how they pour upon us, struck into 
Our place in nature.

Starlight on the sea.

new life by the shimmering ocean! We are subdued, saddened, perhaps humbled in the presence of the great elements; we feel our inconsequence, our insignificance. What place have we in this dream of glory, this golden patterning upon the blue? We watch it weave and ravel-that track of moonlight on the sea -and fondly imagine that it shines for us alone; but it glitters just as brightly along many leagues of shore and sea where there are no eyes to see it. The moonlight and the sunlight with their broken reflections in the wave are for all the world alike, and we-perhaps we are no more than spots of color like the tiny waves that make up the Angels Pathway, or merely diminutive eubes in the golden mosaic of Creation, touched into momentary light by the passing splendor.

It would seem as though splendor had reached its vanishing point when the moon, grown cold and white, sinks below the western horizon. But no. The sky turns deep purple, the waves snap and sparkle in sharp points, the shadows gather closer about the ship; but the stars are the brighter for their dark surrounding sky, and for the darker mirror in which they are reflected. How they glitter above and below! Dark fields of sky dotted with the splen- 
dor of the constellations and grirdled by the Milky Way-what mantles of the Invisible are these! And what elusive, intangible beauty! How strange the thought that the light above shines through the blue, not from it; and that from below it comes up to the surface as from the very ocean depths!

Mere points of light glittering in the air and rocking in the water! Yet these were the guiding stars of the Tyrian and Sidonian ships long centuries ago. The Portuguese and the Italian trusted to them when the compass forsook them. steering by the North Star-a mere manifestation of a world millions of miles away. And are we not to-day trusting to the sun shining upon a sextant-another light far removed and uncomprehended? Surely we have walked by faith and not by knowledge all the days of our years.

Midnight and stars on the sea! What mysteries lurk in those soft windless nights when the black yard-arms go swinging slowly across the constellations, when the black smoke trails far behind, and the bhe-black water glances all Dark windless nights. around! Oh, the dark beauty of the blue, the serene splendor of the starry white, the intensity, the immensity of this transparent world! We glide through it steaming, under the Bear 
or under the Centaur; but the beauty never fades, the mystery never vanishes. We are moving hither and yon, within the great Blue Bowl, wondering at the light that comes filtered through the encompassing arch, and imagining vain things about the canse of it; but we shall not know. Whether we steam at noonday or at midnight we circle within the arch; around and around the uttermost rim perhaps, but we never pass out. There are limitations-even to human fancy. 


\section{CHAPTER V}

\section{OCEAN PLAINS}

How like infinity itself, rather than its symbol, seems the sea! The great bulk of it, the wide spread of it, the far reach of it, are appalling. Horizon lines are not its boundaries, nor blue walls of sky its eonfining barriers. There is no place of its beginning nor yet again of its ending. Its continuity is unbroken. The land seems but a handful of islands sown carelessly here and there upon the waters; but the sea stretches out unceasingly, kecps circling on forever. The sun never rises, never sets upon this kingdom of the wave. Alternate rounds of night and day follow each other about the shining surface, but it knows no time, no past, present, or future. It had no youth, though we speak of its formative period; it will never have age, though we speak of its centuries of existence. Nothing can prevail against it. No climate, no season, no convulsion of the globe, can more than agitate it for the passing moment. Storms ruffle its surface, winds plow 
Enturance of the sea.

The Pacific from. Mexico. it with ocean currents, tides sway it in its basin, but it always returns to itself. The sun drinks it up in evaporation day by day, but it is not empty; all the rivers run into it, but it is not full. Oh, the immutability, the eternal endurance of the sea! 'The earth and that which rests within it is groumd to dust at last and blown about the windy heavens; but the sea never fades or disintegrates. Indestruetible, imperishable, it lives forever-always the same sea, always the same beauty.

Type of all the oceans, sea of all the seas, serene in its uneonquerable might, rests the vast Pacific. Seen from the high tablelands of Mexico and by contrast with the uneasy peaks of the Sierra Madre how supreme is its repose! The white cone of Popocatapetl seems struggling with its encompassing clouds or straining upward at the heavens; but the $\mathrm{Pa}$ cific is at rest, self-contained, aspiring to nothing, disturbed by nothing. How could such an immensity be otherwise! The "Western Ocean" of the Greek, the Seven Seas of the Arab, * the Atlantic of the fifteenth-century

* The Seven Seas were the Green (Indian), the White (Mediterranean), the Black (Euxine), the Blue (Persian), the Red Sea, the Dead Sea, and the Caspian-all of them near the cradle of Islam. 
explorers, what were they compared with the great bulk of the Pacific leading outward to the Southern Ocean! Its expanses are unknown even to this day. Sails come and go along the The Southern Ocran. well-traveled lanes, but in the hinter sea there are lonely wastes that only the explorer, the whaler, and the shipwreeked have seen. Immense fields of water never parted by the eutwater of ship or steamer lie between the Cape of Good Hope and Cape Horn; and as for the Polar Seas at north and south, they still keep silence under the aurora and the midnight sun. Perhaps half of the Pacifie is as yet unexplored, uncharted; and lies in lonely isolation, all unconscious and all careless of its loneliness. What signifies the coming of a white-sailed I'nexplored waters. ship more than the passing of a gray-winged albatross or the churn of a steamer more than the surface lashing of a cachalot!

In summer days from these lofty heights you cannot always see the uttermost rim of the Pacific. The horizon line is lost in a lilac haze, a colored mist, where sails of ships "hull down" glimmer ghost-like for hours and then slowly slip below the verge. The further distance is mystery; and so thick is the air that even the nearer sea has an indefinite look. Far down along the shore the white edging of foam 
shows where the swell is breaking on glittering

Looking from Mexican highlands.
Ocean nells. beaches; and farther out, through loopholes in the haze, may be seen the flash of little waves. The smaller movement of the surface is apparent as through a veil. The idle, uncertain wind ruffles the water in great fields of green or amethyst, a vagrant cloud, white as Orizaba's cap, trails its reflection in the deep; and far and wide upon the outstretched waters is the rain of sunlight falling in a silver shower.

But there is a greater movement beneath the surface that shows at its best only on cool days and with a clear horizon line. This movement is the deep ocean swell that seems always rising and sinking in or near the Trade Wind regions of the Pacific. The surface may be like glass, but underneath there is the heave of long far-traveling undulations. These are not rery high, and rise to no distinct crests; but they are often six or eight hundred feet in thickness, measuring from hollow to hollow; and resemble more the rolls of a Dakota prairie than the storm waves of the North Atlantic.

The glide forward of these long silent ridges, the ease of their movement, are astonishing. Ridge follows ridge and hollow suceeds to hollow without the slightest sound or effort. 
Along the horizon line they can be seen "humped up" against the sky, traveling in Movement of the unending procession, moving in rhythmic sequence, without splash of wave or dash of foam. That they should rise and fall for days with an unbroken surface is still more astonishing. They roll and unroll the reflection of the heavens, they flash the sun, moon, and stars on their slopes, they mirror the dawns and the twilight upon their hilltops; but they never break with their own weight, nor form false curves with their own motion. When they run over shoals or dash up a beach they rise into crests and fall like other waves; but in deep water they come smooth-faced, lift the ship with a great slow heave, slip under it, and are gone Glassy surfaces unbroken. on the other side, with no flaw made in the glassy surface, no disturbance of form, no shock of breaking water. When a breeze springs up it puts tiny facets along the ridges and crests, and these may run into a rough chop sea withont seriously disturbing the movement of the swells. It is not until heavy storm waves set in that the sequence is broken.

But these deep rolling undulations are known chiefly in the tracks of the Trade Winds and extend over into the Regions of Calms. They are set in motion-kept in motion-by 
Slight surface moveinents.

The orean steamer.

Modern stips and sea travel.

the steady pressure of the Trades. Elsewhere on tropic seas the surface may be smooth, and apparently flat, though there are always some slight movements beneath the surface, such, for instance, as the tailings of distant storms, the heave of the tide, or the interchange of currents. These are, however, little noticed from the ship in mid-ocean. Sometimes there are days succeeding days when the only break upon the surface is made by the cut-water, and the only foam seen is that pushed out by the shoulder of the ship.

Not unprofitable are the sea studies made from the deck of the ship, even though that ship be an ocean steamer. The ancient mariner who passed his boyhood in a whaler, becalmed in the horse latitudes or freezing off the fagend of New Zealand, has some contempt for the modern wedge of steel that plies between the continents. He thinks we have fallen upon eril times and that we no longer see the ocean or enjoy travel upon it. The thought is not new. Our grandfathers argued thus and so in favor of the stage coach. Every age is the "good old time" save our own; and every ship looks romantie but the one we sail in. Yet change as we may our vehicles of travel, the sea remains the same; and if we have observant eyes there 
are still beautiful things to be seen from steamer decks or even from the bridge of that peace destroyer, the private yacht.

And a fast-trareling ocean liner of twenty thousand tons will make beautiful things out of the water she passes through and pushes aside. The little dash of spray under the vessel's fore-foot is of slight interest, but the tremendous furrow turned and rolled out by the shoulder of the ship is worth some study. A wall of water goes bumping, daneing outward with a shoek that inmediately shows in millions of tiny bubbles, in vivid greens and blues, and in curling crests of foam. With foam comes dazzling light; and nothing is so dazzling as foam, save only the newly fallen snow. A probable explanation of whiteness in the snow is that each flake is a crystal-a prismthat shows on its edges all the colors of the rainbow. Color is merely disintegrated white light and, when thrown together in such masses

The ship's furrone.
Whiteness of foam. as the snow erystals, it re-combines and comes to the eye as an intense light. In the case of foam the break of the wave allows air to intermingle with the water. Countless tiny bubbles, half water, half air, are brought into existence; and each one of these displays on its surface the colors of the rainbow. The unity 
Crests of foam.

Colored crests.

in mass of these colors again produces to our eyes the effect of white light.

It is of no great importanee, so far as the foam at the shoulder showing white is concerned, what may be the local color of the water through which the ship is traveling. Sometimes there is a great milky erest of it thrust up and ont from the ship while slipping backward into the hollow are long strings and ribbons of white. Very beautiful are these patterns of white that appear with some regularity up and down the dark hollows of the first waves. They are soon dashed to pieces by the wash along the steamer's side; but, for a moment or more, they are flung into forms that suggest thin drifts of snow upon blue-green ice, or festoonings of lace upon an emerald field, or, again, ropes of diamonds decorating mirrors in some winter palace of the fairies.

Nor are these festoonings always pure white. At evening when the sun is on the horizon, its light may strike the clouds above or abeam of the ship, and turn them lilae or yellow hued or rose colored. This eloud-coloring is instantly repeated in the foam of the shoulder swell-sometimes showing as pink on aquamarine and again as gold on deep blue. The vagaries of light with their consequent side re- 
flections are innumerable, utterly impossible of recording; and yet always astonishing with each new manifestation.

The light that lies in foam is not eclipsed when the sun goes under a cloud. It is still very white; and even at midnight, with no moon or stars, the break of the wave is disWave crests at night. tinctly seen as a pale flash in the darkness. Every one who has experienced a heavy storm at sea will not forget the ghostly gleam of the white caps in the night and the great dash of white waves up and over the ship's bow. The darkest night with clouds will not completely eclipse the light of the wave crest.

Up from the foam of the wave is flung the spray of the wave. The thin cap is tossed in air by the lateral thrust of the wave base Spray and is scattered into tiny drops that flash in the sunlight. The brightness of this spray is, again, dazzling. It seems like liquid light flung skyward from some subterranean fountain. Eren as it flashes it seems to disappear in water dust, to be blown to pieces by the winds, and drifted aft as a mist. When it reaches the proper angle, and is struck by the sun anew, the mist turns into a rainbow. It is only a little bow-an amusing little archthat we watch with perhaps a languid interest. 
Frequently there are several of them at once and they travel with the ship, maintaining their form and place, as long as the spray drives and the sun shines.

Back from the dash of the fore-foot and the spray of the shoulder are the tumbled waters

The ship's wake.

Silver light in the wake.

Phospliorescent light. of the stern-the waters beaten into tiny bubbles by the churn of the propellers. The larger bubbles soon disappear-evanesce as it werebut far away behind the effect remains, the wake is apparent. This slash in the sea shows not blue but green, the local color of the water; and not until long after the ship has passed does it smooth over and return to its reflected sea-blue. At night the trail of the steamer instead of being green, sometimes looks like a pathway of shining silver running through deep pansy-purple. But this is due to no normal coloring. It is phosphorescent lightsomething that will bear a word of explanation.

It seems that the surface of the ocean is, in certain areas, covered with swarms of animalculæ. Drifting upon the water the passing of the ship disturbs these small creatures, and, in fright or anger, they emit a white light like a tiny spark of electricity. It flashes for a moment and then goes ont to be renewed again in a few moments. When the ship rushes 
through a great drift of these minute organisms, and millions of them are overset and frightened into fire, the effect upon the sea is very marked. It glows like a metallic surface. This is perhaps seen at its best from the taffrail looking down the wake; but the bow and sides of the ship-wherever the water is disturbed-will show lines of pale fire as well, while outside of the disturbed area the sea remains its normal darkness. A disturbance of the surface is the usual cause of this phenomena; though in southern seas of tentimes there are great areas of animalculæe that, of their own volition, will glow at night and cast a light upon spars, and sails, and human faces almost as powerful as moonlight.

Equatorial waters are the most favorable for phosphorescent appearanees though similar appearances are frequently seen at the colder north. The tropical seas, with their heated surfaces and thick strata of atmosphere, are also famous places for electric phenomena and for illusions of the air. Here is seen the St. Elmo's St. Elmo'i Light, the fata morgana or misplaced image, and also the true sea mirage. The last named appears when the sea is ealm, the weather very hot, and the air strata above the water are very thick. It looks like a long, glittering band of 
Sea mirage.

Fata

morgana.

The ship in the air.

silver lying along the horizon, and quivers slightly or shifts place not unlike the aurora. The sailors explain it by saying the water is "reflecting itself," and possibly that is true, the water refleetion being seen upon the air; but a similar illusion is produced by the sky being reflected from the denser air that lies along the surface of the sea.

The water mirage is a very beautiful illusion but not one of frequent oceurrence. Nor is the fata morgana, where things are seen out of their plaee and "upside down," an everyday happening. The object is generally noticed "looming" high above the horizon, and is usually a ship, an island, or a coast eity. Sea captains frequently tell tales of seeing their port of destiny in the sky long before the port itself comes up over the ocean's edge; and the sight of a ship in the air, hanging masts downward, is something that almost every sailor can spin a yarn about. The reversed ship does not, however, appear every day or every year; and many a tourist, boastful of the number of trips to Furope he has made, has never seen it at all. The cause for the distorted and misplaced image is the thick strata of low-lying air which bends the light ray so that we see not in a straight line but in a eurved line. From ex- 
perience we think we see the ship in the air by the straight ray, whereas in reality we see the ship on the water down below the horizon line, by the bent ray.

The sea air, when it becomes thickened by heat or is moisture-laden, often shows as a silver or gray or pale blue mist. Thin sheets of it may be seen in the early morning hovering above the surface of the water, making perhaps strange illusions-strange likenesses to things seen upon the land. For frequently mist or fog will throw a yellowish reflection on the water giving it a look like drifted sand; and the patches of blue sky reflected in spots through the yellow produce the strange effect of blue lakes in a desert. The space directly overhead usually shows no definite patches of mist and from its diffused white light it would seem as though the upper air held the mist in solution. It is certainly a moist upper air that is responsible for such effects as "the white horizon"; and it is the same air. hanging above The white horizon. the still sea and reflected in it, that gives the pearl-like surface of the water so much fancied by our modern marine painters.

A morning mist veil at sea stretching across the illuminated east, making the rose of the clouds and the azure of the sky look faint and 
The mist veil as a crentor of colorbeauty.

Lunar rainbows.

dream-like, is always a potent source of beauty. And of mystery. How cunningly 'Turner used it to throw a glamour and a charm about his towers and turrets and cities by the sea! How cleverly and yet how truly Monet, in his Thames pictures, revealed the beauties of sunlight by filtering them through this same veiling, this same beautiful mist of the morning! As for Claude Lorraine, whose name our English friends still invoke as though no modern had ever reached up to him, save Turner, what charm would his classic bays and harbors possess if it were not for their golden sea-mist of sunset!

And what pictures, never painted by master ancient or modern, are to be seen by the weather rail at night when the lunar rainbow with its arch of subtle light-and-dark follows on the ship's beam, when the purple water flashes through the patches of the mist, and overhead the moon is like a silver disk, the stars like phosphorescent points! The summer nights upon the Agean when the small island steamer sweeps you past Syrian ships becalmed - their hulls lost in the low-lying vapors, their sails looming above the drifts into the white moonlight-are never to be forgotten. They are only impressions of intangible light and 
color, momentary revelations of pictorial poetry without literary meaning or association; Summer and yet very insistent revelations, very striking impressions. We do not readily define them but we feel their effect upon us, nevertheless. It is an efiect analogous perhaps to that produced by music-pale music in a minor key, dreamy musie that moves in slow-heaving eadences or faints in realms of sun-shot haze or gleams in chords of lustrous silver.

The division line between mist and fog lies somewhere in the aerial envelope. The same indefinite line separates fog from cloud, though they are practically one and the same thing. Both are visible vapors, the one several thousand feet in the air, the other lying along the surface of the earth or sea. Both differ from mist only in that they are more concentrated in form and strata. And there are bcauties of color in the fog as in the mist. It is by no means such an unalloyed evil as the nerrous person who dreads a steamer collision fancies. Instead of dull leaden hues the fog is often luminous with pale blues, lilaes, mauves, and silvers; and it is never remotely approached to black, though the term "black fog" is applied to banks denser than the ordinary. 'The colors are not, however, usually seen because people 
Beauty of fog effects.

Iceberg8. will not try to discover anything but discomfort in a fog. The drive of the steamer through the vapor pall, with the siren shrieking every few moments, is counted one of the horrors of the North Atlantic voyage. And, true enough, it is not always a pleasant or agreeable happening; but the fog is an ocean beauty none the less. Standing beside the lookout at the bow as the steamer plunges forward into the unknown, each new scrap of sea is eagerly scanned as it rushes aft along the ship, the waters flash and disappear, the fog-bank cleaves in twain, we speed on and away through changing clouds of blue and silver. There is an exhilaration about it to which the warning note of the siren perhaps adds the spice of danger.

The danger is the more real on the Newfoundland Banks when the water and the air suddenly grow cold. That is the first indication of icebergs; and ice is perhaps more fatal in collision than a sister ship or a water-logged derelict. It is some time perhaps before the bergs appear on the horizon. When they finally lift into view we are perhaps surprised by their modest dimensions, and wonder that such small scraps of ice could cause so great a chill upon the waters. But doubtless we fail to consider that more than four-fifths of the white 
monument lies below the water level. The mass underneath is enormous, though how, even with all its bulk, a dozen bergs or less can chill water and air twenty or thirty miles away is something of a puzzle.

Close to view the iceberg is often wonderful in color. With different lights it takes all tints of azure, turquoise, and Nile green; and in its shadows it shows all shades of blue and violet. The sheer ice wall is usually a dark sea-green, suggesting the local color of the water from which it has been formed; but when the sky is clouded it often shows a dead-white surface. After it is honeycombed by sun and disintegrated by warm winds it loses much of its bright coloring. In form the floating berg takes on fantastic shapes, because the harder cores of it are the last to melt; and they often stand in strange towers, columns, and turrets after the softer parts have cracked and fallen away.

The northern fields of ice, with all the splendor of the arctic twilights and midnights, the auroras, sun-dogs, brilliant colorings and

clear reflections are wonderful enough, if we are to believe the tales of our explorers; but they seem to have little to do with the sea. Once water is frozen and its pliant surface

Turreted forms of icebergs.

Polar icefields 
destroyed, its identity is gone. The pack-iee and hummock-ice do not even suggest frozen waves. They are merely a gorging and heaping of the ice-fields.

Snow, too, seems foreign to the sea, though, of course, it does fall into the open oceans in the temperate and arctic zones. Even a crossing of the North Atlantic during the winter

Snow at sca

Falling rain months is frequently accompanied by a snow storm. It is all in the air-a driving of white particles across a dark sky, down, down to a darker sea. Instantly the snow touches the water it perishes, vanishes without leaving the slightest impression or trace of itself. Sometimes in a very heavy downfall it will make the sea surface look white for a few minutes; but the salt water soon absorbs it, destroys it.

Rain at sea when it falls in vertical lines and strikes flat water does so with considerable force. The impact of each drop makes a pit in the surface, a splash, and a rebound. When it is falling rapidly, it not only creates something of a roar but also something of a bubbling surface upon the sea. In the tropies, where the drops are often heavy and close together, the sea will be foaming-white even in the darkness of night; and after the rain has passed the surface will smooth out, look oily 
and glassy, and rest perfectly still as though beaten into quietude.

The driving rain that waves through the air, like the folds of a huge flag unfurling in the Driving breeze, is something very different. The drops are small and fierce enough in their impact, but striking the sea diagonally they make no pitting. Tirey seem to lash the surface with long lines of trembling spray, or break it into little waves that go shivering and quivering in erratic dashes with each new gust; but the effect is only of momentary duration. In heavy seas, when the wind is blowing with hurricane force, the fall of rain is even less marked. The wind seems to drive it into mist and mingle it with seud and rack, until at times they are not distinguishable apart.

Sometimes before thunder showers and squalls of wind comes an odd feature of the sea-the water spout. It is caused by wind and, so far as I know, is the same phenomenon as the great dust whirls which one sces on the deserts. The dust whirl is a long, thin column, sometimes twenty-five hundred feet in height, which moves in a solemn, stately fashion across the sands, its head in the sky, its foot on the earth, catching up sand and dust in its hollow trough, whirling it high in air, and finally, 
The spout; how formed.

Evening light after ruin. when loosed from the vortex, allowing it to fall slowly back to earth. The water spout is not unlike it but is a trifle more energetic. It usually forms just under the black wind clonds that immediately precede the gray rain clouds; and it extends down from the clouds to the water in a "spout" or funnel. When it meets the water it causes some agitation, but not nearly so much as is pictured by imaginative writers. Sometimes water or its spray is carried up in the whirling funnel, but usually there is only a foaming and dashing of the sea surface directly under its foot. After ten or fifteen minutes the spout generally breaks and the contents (if there be any) descend as rain. Its appearance is usually very deceptive. We think it is a column of water extending from sea to cloud, but in reality it is a column of mist surrounding a central axis of rarefaction. It moves with the storm and often has brother spouts for company.

Beautiful, indeed, is the clearing away at evening after rain and storm, when with lifting clouds and vapors comes deep blue sky; and perhaps far away a faint gray something is seen taking form along the horizon. Land ho! is the cry forward. But where? It is not readily seen even when pointed out to us. Our eyes grope 
along the dim sea-line looking for land, which is really the last thing we should look for if we wish to see it. Presently we seize upon a pale outline that seems to enclose a pale blue land in clond. That is usually the first appearance of land from the sea, especially if it be a mountainous coast. The rocky top shows first. It is seen through a thinner stratum of air than that lying close down along the water, and hence appears clearer and nearer. As we approach, it begins to darken in color and take sharper outline against the sky; but it still remains as a flat clond-like affair with its base cut off by thick layers of atmosphere. When it finally begins to show depth as well as width and height, it also begins to reach down and have a foundation in the sea. Last of all is Appearance of rocky coasts. seen the white foam of the beach or the dash of waves npon the rocky coast.

Quite the opposite of this is the approach to a low-lying shore where there are no mountains or headlands or even tall trees, where there are long lines of sand spits and flattened dunes ereeping down to the water's edge. The land now shows as a long half-submerged line upon the water like an enormous sea serpent stretched out asleep. It lifts a little as we approach, shows inequalities here and there; shores. 
A pproach to lagoon islands.
Islands of the Pacific. but it is some time before it takes definite body and becomes substantial shore.

Still different is the approach to what mariners call the "low" islands or "lagoon" islands-the coral formations of the tropic seas. Again, the last thing to look for is an island. The cocoanut palms, mangroves, and other large-leaved trees that usually grow upon these atolls, make up, at a distance, a band of olive-green that cuts in between the gray-blue of the sky and the deeper blue of the sea. It rests between the sea and sky for a long time as a mere puzzling coloration. As we come nearer, however, another band of cream color forms under the green and becomes recognizable as a beach; while still below the cream color is a line of shining white, indieating perhaps where breakers are dashing over coral reefs.

The rounded island of the Pacific, lying like an emerald set in a sapphire sea, how beautiful it seems to wanderers of the watery waste! Low down it rests upon the great bosom-an oasis in the desert, an island of palms in the wilderness, a haven of rest without tumult save of the surf, without sound save of the surge, without time save of the tide. Born in no convulsive throe of nature but builded skyward through many a year by the 
ceaseless energy of tiny polyps, a mere point of limestone in the deep, how firmly it withstands the wash of the sea and the wear of the wave! Tides ebb and flow, winds come and storms rush by, but the citadel grows stronger, lifts higher, becomes more beautiful. With its ferns and shrubs and waving palms serenely it rests under the southern sun and sky, a mere speck in space; yet what a refuge, what an earthly paradise!

Those clustered islands of the Pacific that welcomed Cook and sheltered the mutineers of the Bounty, what romance clings about them still! Utopias of the sea, where nature always smiles and art is still an unknown story, were ever yet such fairylands for poetry and song! And how inevitably they provoke a contrast and pose again the question of human happiness! What vantage comes to us from a boasted civilization, how bettered are we by Romance of the South Sen islands. place and power and wealth? Men beat down friend and foe alike, and uproot beauty on the earth and in their own hearts, to gain an evidence of riches; but what avails the horde that brings no joy? Heap surplus upon abundance, crown knowledge with enlightenment if you will; but a naked savage by these southern shores with his bread-fruit, his sun- 
Concerning happiness.

The modern view of happiness. shine, and his music of the seas is more content. Happiness is not hidden in a bank vault or a philosophy; it is in the free air, under the blue sky, in the mountains, on the prairies, by the seashore. Contentment is not attained by possessions or positions, or pursuit about the globe; it comes to those who will but fold their liands and wait.

Old truths these-old when the world was young-but the new generation flouts them, scorns them, laughs at them, thinking that the tale of human happiness shall be different with this new time. It nurses the strange belief that all the good things of life can be had by a bold dash in the lists of Mammon, that every prize is there and within the reach of the knight who will but ride boldly. Ever the golden bugles are calling, calling to enter the lists. And the gentle song of the sea, wooing to love and to beauty, is lost in the clash of the conflict. 


\section{CHAPTER VI}

\section{THE WIND'S WILL}

THE word "restless" that we continually apply to the sea is somewhat inappropriate and misleading. If there is one thing above another that the sea would avoid it is restlessness. It is ever seeking to keep still, to lie flat, to maintain its normal equilibrium; but it is ever being pushed out of place and jostled into daneing points by the winds. The winds are the disturbers of the peace, the uneasy wanderers that keep driving the water hither and yon, from deep to reef and from reef to deep again. At first the water offers some resistance, some defense. It is not a powerful opposition, however, and the winds soon break through it; but the water has a way of reasserting itself at the first opportunity.

The defense is merely the covering that spreads over water when not in motion-the skin that holds it intact until shattered by some sudden shock or jar. This skin is an elastic envelope that often requires a hard 
The skin of water drops.

Covering of the seasurface.

Stretchang of the covering. shaking to break. The dewdrop on a leaf may be rolled about very roughly without losing its form; and the beaded drops that edge a window sash in time of storm are not easily shaken from their moorings. As for the form of the ordinary raindrop, and its persistence in roundness even when hurled violently through the air, they are both due to the skin or envelope that encloses the drop.

This same thin covering protects the surface of the sea in periods of calm. It has no name (though the Provençaux speak of a mer d'huile) and is hardly to be analyzed; yet its presence is apparent enough. When a little puff of wind strikes the surface a stretching of the envelope is noticeable. A ruffling and a quivering seem to run over the water. But these "flaws" of wind or "cat's-paws" come and go and leave no permanent disorder. The skin gives like thin india-rubber, but it does not part or break. It is really quite tough and when oil is added to it (as sometimes in storm) the mixture or combination is strong enough to baflie a stiff breeze.

When, however, the puffs of wind grow too strong or too steady, the shivers and quivers that run across the water at last break the surface here and there. The skin envelope is 
perhaps ripped like a pice of tissue paper. The wind now has a rough edge to push against Breaking instead of a smooth surface; and it drives so hard at this point that the water just ahead of it is forced upward into a tiny wedge or wave. The wedge itself at once becomes an upright face that eatches the wind. It is driven ahead with a push that causes its top to outrun its base and thus sink forward and downward. The fall displaces and drives into wave form the water ahead, helping on the further breaking of the envelope and the formation of new wedges. Presently the whole surface of the waters is covered by tiny waves, flashing with a thousand facets, and making what is called " a ruffled sea."

Sometimes just before an approaching storm, and apparently without any wind, there is an unaccountable agitation of the surface. The small wares seem much excited, leaping up in little points, and breaking off abruptly with a The sea before a storm. dull swash. But usually the disturbanee of the surface increases only by continued pressure of the wind. The ruffled sea passes into the "chopping" or " choppy" sea by gradual transitions. The more upright surface exposed and the higher the apex of the wave, the greater the force hurled against it, and the stronger

The ruffled sea.

of the covering. 
The choppy

sea.

Favorite spots for choppy seas.

the drive forward of the wave itself. The water wedges, under such conditions, soon rise and fall in regular series and move with a well-defined drift in one direction. They are not yet of great height, nor thick through from base to base, nor rolling like the smooth undulations of the tropics. They are thin sharp waves that have a way of pitching upward - "dancing" it is sometimes called-and a spiteful fashion of striking the gunwales of a small boat and dashing water over its oceupants.

The "choppy" sea (by which is meant a cut-up or an up-and-down sea) is usually met with where the wind is blowing against an ocean current or a tide coming down a bay. The English Channel is its favorite haunt, especially when the wind is blowing up from the sea; though it is seen everywhere when winds are variable and tides contrary. The region of the Trade Winds seems sacred to the long roller, but even here a tropical squall will beat up the short wave; and around the Cape of Good Hope they ride the backs of cnormous swells, maintaining an identity of their own even though joined to a greater movement.

The "white cap" adorns almost all the shorter forms of waves. It is merely the thin 
end of the wedge pushed up so high that, unable to sustain itself, it curls, bends forward and downward, and breaks into foam as it falls. Almost always it is pushed ahead by the drive of the wind against it, the heavier base not being able to keep up with the erest; and in stormy weather it is frequently whipped away by the winds and driven through the air for long distances in the form of flying spray. In an ordinary gale of wind these white caps ("Flocks of Proteus" is the pedant's phrase How they break. for them) are to be seen in every direction, breaking usually with regularity, and flecking with white the whole surface of the sea.

Very beautiful from the ship do these crests appear. We watch them flashing in spots of light hour after hour, and think of the ocean as at play in the sunlight, when in reality it is simply being buffeted by the winds. The waves dash here and there as though frightened and Appearance of white caps. in their eagerness to escape sometimes break against each other, often confounding confusion in a small roar of foam.

But there is another side to this whitecapped ocean that no man knows so well as the swimmer who has wrestled with it. With eyes down at the water's edge, and head ridThe swimmer in a ing up the slope of an oncoming ware, the choppy sev. 
A dangerous sea.

Waves with a half gale. outlook is anything but assuring. The ridges appear enormous, the horizon instead of being that is as ragged as a sky line of snow-clad Alps, and the spray seems to reach to the very zenith-white spray leaping upward at a cold, white sky. When the swimmer has swung down into a wave hollow he seems walled with blue-green water, and when he dives through the crest and comes out on the sloping back he seems to see legions of waves hurrying toward him from every point of the compass. It is a wearying, worrying sea. The waves never cease, the crest must be continually avoided; and ever and anon the unexpected cross wave breaks over the swimmer's head with a wild rush. If he comes through alive he never forgets to his dying day the look of that foaming sea.

White eaps are accompaniments of the larger as well as the shorter waves. With a strong wind both waves and crests increase in size, but there are fewer of them. The water seems to swing in broader and longer ridges and there is no great regularity in the wave forms. OWing to flaws in the wind cross waves are set in motion, tolis of water are pitched here and there at odd angles, the sea becomes "lumpy" in spots and "full of holes" in other places. 
The crests now appear of toppling height, and when they break they do so with a roaring swish of spray. 'This is what the sailors would call " a rough sea" and the wind is "variable" or "a half gale."

The storm waves which appear with very high winds are peculiar to the winds that form them. If the pressure is steady and continued from one direction they have a tendeney to regularity of movement; but not if the wind comes from thunder storms or cyclones which last only a few hours. These gusts merely lash the ocean, tossing and twisting the surface and, after much bluster, subside as rapidly as they rose. Indeed, the original dash of wind and rain has a tendency to beat down the water instead of driving it forward in ridges; and in any event the thunder storm is usually much too short-lived to start a procession of heavy waves. But under the long and strong push of a three-days wind-a "northeaster"- the sea heaps up in great valleys and ridges that grow higher and heavier with the increase of the gale. They are not always foam-eapped, but frequently a ware of Effect of
"then norlheaster." greater bulk than the others will come pushing and shouldering along, its apex wedged up so high that the unsubstantial fabric of water 
Spume and uater dust.

Flying

scud.

A stormy set from the ship's cross-trees. cannot sustain it, and it lets go with a crash, pitching forward in a long whirl of white.

Upon the backs of these great waves are many smaller waves, thousands of broken facetings of light, ruffles, rips, and tears in the transparent mantle; and after the first or second day there will be patches and broken wreaths of spume--battered and beaten water dust-hanging along the waves or rolling from ridge to hollow in an aimless and lifeless way. When the wind reaches hurricane force the sea surface is half-hidden by its own spray. Sheets of water are continually lifted from the high ridges by the wind, blown to fine rain, and driven with a whistle through the rigging of the ship. This spray is mingled tempestuously with the moisture of the clouds; for though it may not rain there are usually clouds, lying low down over the ocean, the under parts of which are wrenched away and hurled through the air as flying scud.

Seen from the cross-trees of a ship-the cross-trees where you cling and swing backward and forward over the water as the ship plunges with an awkward stumble or rights with a violent snap-a stormy sea is a sight to be remembered. There is no far view obtainable. The blend of spray and cloud rack 
make a watery atmosphere that shuts down upon the sea at short range. Overhead there is a gray turmoil of torn clouds and all around Color of water in is the pitch and toss of the wind-driven water. Its color is generally steel-gray or olive with foam-white for the high lights; but in the break of the wave on the ridges and in the swash of the water against the ship's side there are wonderful greens churned into beingberyl-greens, emerald-greens, bottle-greens.

Very striking are these colors in storm; and yet they are rather overlooked, forgotten, in the wail of the wind throngh the rigging, the drive of spray, and, above all, the forms and movements of the waves. All varieties of rolling, tumbling, tossing waves are here-long lines of the foam-crested roller, sharp edges of the ragthe waves. ged cross wave, great banks of water that push but never break, spiteful caps that break but never push, waves upon the backs of waves, lone waves, double waves, thin wares, wild wares. There are never two of them quite alike. And the continuous untiring volley of them! The wonderful movement and restless energy of them! The curling, twisting, writhing beauty of them! They are always graceful. The elasof waves in ticity of the material makes it impossible for motion. them to lack in flowing line or want in just 
"ItTares mountain high."
The height of storm wave8. proportion. Sometimes they are broken by the heaviness of the wind or by cross surges; but usually the outlines hold intact and the waves sweep on and out of sight with a serpentine grace unknown to any other element.

The size of these wave forms in mid-ocean is something not usually known to the tourist crossing summer seas. The "waves mountain high" that he may chance to meet with in a September gale are only fifteen or twenty feet high; and the hurricane waves of mid-winter, which he seldom sees, do not rise more than fifty feet at their greatest. They look more formidable than their statistics; but I believe it is generally conceded that no one has ever seen a wave more than fifty feet in height on the North Atlantic. In the Antaretic and in the Cape of Good Hope region, where there are long and strong winds with very deep seas, the height is greater, especially with the exceptional wave called by sailors a " gray-back"; but even there one meets with no "mountains" of water. From hollow to crest in a perpendicular line it is doubtful if any wave ever rises so high as a hundred feet. This of course refers to waves on the open sea and not along shore. A breaker may be dashed up a rocky coast to a greater height than that by its tre- 
mendous velocity and the push of water behind it; but the coast breaker is not the same as the free mid-ocean roller.

Modest as the smaller figures may be they, nevertheless, represent a mighty moving power; and a sea covered with fifty-foot waves is a fearsome sea. It is never seen in shallow depths nor in narrow bodies of water. The English Channel, made up of much fresh water filtered through the Baltic (and fresh water, being lighter than salt water, may rise to a The English greater height), is only a shallow arm of the ocean; and for all the "great guns" that blow through it the waves are not of great height. They look formidable enough, and every traveler to or from the Continent has his tale to tell about the horrors of the Channel. It is a place where choppy seas foam into cataracts, where bulkheads and docks are battered to pieces in storm, where cliffs are undermined, and vessels are wrecked, and men by scores are drowned; but it never knows the heavy waves of the open Dangers of the Channel. Atlantic. Its waters are not deep enough, its open spaces are not wide enough, its moving wedges cannot travel far enough to lift into ocean waves.

And yet the Channel ean show its white teeth in storm in a way that commands both 
Winds along the Channel and the North Sea.

Everything driven off the water.

Storm on the coast of Holland. respect and fear. The winds usually find a trough of low pressure along this waterway to the North Sea, and rush through it with great fury. Sometimes for days at a time they blow, carrying with them low clouds torn into fragments. driving ahead of them spin-drift ripped from the surface of the water, and sending the rain flying in lines with an almost flat trajectory. In such blows everything living or movable is driven off the water. The packets cease running, the sailing ressels seek harbor, the wild ducks fly inland to the quieter bays and harbors; and even the sea gulls and curlews will be found back on the English meadows, each one squatting behind a tuft of grass or a little knoll of ground, taking the wind and rain with a diagonal slant of body from head to tail, and riding ont the storm as best he can.

As you come down from the interior to the dunes of Holland in such a storm the effect is weird, almost unearthly. The light is gray, the clouds are blown to picces, the sweep of the wind is terrific. Flying sand cuts and stings the face, it is difficult to stand upright for the wind; and to escape it you are glad to avail yourself of any hollow in the hills-a hollow perhaps under some dyke with the sound of 
the sea on the other side dashing ten or fifteen feet above your head. Notwithstanding you are in the dunes and away from all buildings there is a reverberating roar in the wind that speaks of the shock in the upper air; and though you are down in a hollow there is another roar that comes rolling in from the sea.

The tumult of the waves is felt before it is seen. Abore the tops of the outer dunes great sheets of sand whirl through the air and shut out the view. In the momentary pauses of gust following gust-between the sheetscomes a glimpse of the North Sea. It is not blue or green or opal but tawny and yellow; not clear as erystal with snow-white crests, but rolled full of grit from the beaches, dirty-looking as though churned with bottom mud. For a half-mile out from shore all the water looks like café-au-lait; and the foam on the waves, the froth on the beach, are as whipped cream. The waves are driving in long diagonal ranks-each one traveling along Look of the North Sea the coast, breaking on its beach end, and finally disappearing from view in sand and spray. Beyond the coffee-colored shore water, where the depth is greater, a clearer sea shows. It is still yellowish, it even borders upon topaz without being so transparent; but from the

Coming down to the sea. 
Night on the North Sea.

The drive of the wind.

shore it merely counts as a color streak. Farther out everything disappears in a confusion of spray, mist, and cloud. There is left only a great gray veil-half water, half sky-that the eye will not penetrate.

Night on the North Sea or the Channel (scen again from the ship's cross-trees) is even more weird and unearthly; especially when there are lightning flashes to illumine the yellow dunes of Holland or the white cliffs of England. In that pale violet light the dunes look like a greater and more tempestuous ocean, the cliffs gleam like phosphorus, the summer hotels along the beach at Ostend rear into enchanted castles, and the tawny sea seems a vast waving desert of sand. And how that wind, blowing perhaps straight up the Channel, up the North Sea, wails through the rigging! Wee-ooh! wee-oooh! Oooooh! Ooooooh! Then a great dash of spray driving up through the bowsprit-shrouds, over the crow's-nest, against the spars; drenching everything above board, accompanied by the heavy pounding of a wave upon the turtleback-the water scurrying aft over hatches and deck-houses, and finally disappearing with a plunge over the rail into the dark of the sea.

Wild enough is a night of storm on the 
North Sea, but wilder still is that upon the open North Atlantic. In latitude $40^{\circ}$, longitude $40^{\circ}$, in the region of "the brave west winds," there is no yellow tinge to the water that comes from shallowness, no short wave that comes from hampered movement. Wind and water are both frec and both of great strength. Hand in hand the waves come marching down upon the straining ship in inexhaustible sequence and energy. And occasionally, looming above the horizon line, swinging and pushing to the front, lifting, still lifting as it nears, comes a liuge "gray-back." With the cry of warning from no one knows exactly where, every man-jack leaps into the rigging and takes a twist of a rope about him as the great comber strikes the shoulder of the ship, rushes up and over the bulwarks, and thunders across the trembling decks. In a moment it has vanished, but it is not long before the warning cry tells of another. All day and the night through perhaps, they come and go, the push and shock are terrific; and the wonder is that ribs of oak, or even of stecl, can stand such buffeting without breaking.

With the sailing ressel there is always some making of lecway, some bending and drifting with the wind, some swerving under the blow. 
The plunge forward of the ocean liner.
The great storm on the coast.
Not so with the ocean liner-the craft that sad sea-dogs tell us is only a floating hotel where we see the calm ocean from cabin windows. A great steamer going twenty knots an hour to the west, meeting a gale traveling sixty miles an hour to the east, will furnish forth more dashing waves in an hour than any ship, bark, or schooner ever encountered in a lifetime. The force of that sharp-nosed craft driven headlong against the seas simply shatters the water into dust, flings it up and over bow and bridge and sometimes smokestacks, whirls it aft over funnels and cabins with a blizzard velocity. The plunge of the bow into the smother of the sea, the heave-up with running decks, the clouds of driving spray with their long-drawn hiss-ss-sss along the whole ship's length, make up about as wild a sight as one ever witnesses upon the open ocean.

And yet fiercer still seems the blow of the wave struck upon the rocks of the shore, and wilder far is the storm seen from some point of pines along the New England coast when a great gale is blowing. Such a storm usually anticipates itself with various warnings. Sometimes the waves arrive before the wind, having outrun the storm that created them; but usually the sea is still, flat, apparently hushed. 
Presently a gentle puffing of the wind is noticeable, with a hum of the pine needles, and a strange little moaning along the clefts of the rocks. It may be some hours later before the sky clonds over, looks ominous or "greasy" as the sailors say; and the rain begins to fall. With the rain the wind begins to rise. The drenched pines gradually eliange their note from a hum to a wail not unlike the sound in the rigging of a ship-Wooooh! Wece-ooooh! The rising surge on the beach begins beating out its regular Booooom-sh, Boooom-sh! Boooom-sh! The wall of granite against which liain, uind and rising the waves go rushing gives back the hollow roar of the sea-War! Waaar! Waaarrrr! Out of the mid-Atlantic pushed by the wind for a thousand miles or more come the great seas. Their impetus is something almost irresistible, their weight something enormous, their striking power something terrific. Higher and higher they rise in the erest as they near the coast,

"Cliffs of emerald topped with snow That lifted and lifted and then let go A great white avalanche of thunder."

When they strike the roek rothing ean stop their upward rush save disintegration and destruction. The bulk of the wave is fended off

llow it

begins. 
The whiteridged ocean.

The seagray coloring.

by the rock-bases; but this only shunts power upward into the crest which is shot into the air and blown to pieces over the upper cliffs with a long drawn Swissssssshlh !

What a sight it is, this white-ridged ocean rolling and clamoring toward the shore, this beaded water dashing high in air! What fresh fury seems added by each new-coming wave, what slashing blows are dealt left and right, what convulsive twist and writhe and strain of the waters! And riding down this chaos, burying it out of sight at times, comes again that monster comber-the "gray-back" of the seas -swinging far up the rocks with a deafening thundering crash, its shattered crest flung high in air and carried landward like a cloud of steam.

As the night shuts down perhaps the wind rises higher and higher, the mingling of spray and rain makes an atmosphere that can be felt, the meeting places of the elements are blurred, and the hne over all is a neutral gray, a seagray-the residuum of wrecked color. Far down along the coast the feeble flash of a lighthouse appears at intervals and out from the reef is heard in momentary gurglings the halfhuman sob of a bell-buoy rising, rolling, and sinking in the waves. Ghost-like in the dim 
light reel and toss the white riders of the storm. Onward they come. Swash! Boooooom! Sssssss-ss! And the great cauldron under the eliff having flung forth its spume, halts, hesitates, sinks back upon itself, sucks out in a Lighthouse and bellbuoy. great undertow, then rises into a new crest higher than ever. Waaarrr! Ssss-ssssss! Weeeeooooohhh!

All night long the pound against the eliffs and the tremble of the shore! All night the whistle of the spray-laden wind as it drives through the branches of the pines! All night the curl and flash of the white erests on The pound of water. the open sea! By morning perhaps the wind has fallen, the clouds have vanished, the sun is forth; and yet for many hours afterward the far ocean waves keep swashing against each other and collapsing in swirls of foam. Finally the sea runs down, the breakers sink; and at sunset as you walk along the beach all is quict. It is hard to realize perhaps that the now The subs. ience.

smooth sea with its placid little swells conld ever have worn such a savage front. But the traces of its fury still remain. The dunes are eut through by inlets here and piled high with wet sand there, the beaches are ripped and torn, the bowlders are rolled over, scarred and battered; and the face-walls of the eliffs show 
Wrecks and wreckers.

The lost.

Flotgam of the wave.

where tons and tons of stone have been broken away and fallen into the sea.

Perhaps far out upon the distant reef, where the white caps are still showing, hung helplessly upon the sharp-fanged rocks, heeled over on her side with masts and rigging all down, is the battered hulk of a schooner that was driven in by the wind the night before. The little black speck that moves slowly about her fore-foot is possibly a boat of a life-saving crew that was unable to save during the storm, and is now only making a perfunctory examination of what remains. Perhaps again the little knot of fisherfolk that is seen crowded together far down the beach has found at the water's edge, half buried in the sand, a cold form with a frayed rope shirred about the waist, purplish hands with torn finger nails, and a white face with wet hair clinging about it as the tide went out. Dead, quite dead! Yes; but what cares the sea! Captain or cabin-boy, prince or pauper, lover or hater, what cares the sea!

The high-water line along the beach always has its tale to tell, its report of accident, its whisperings of disaster. Fragments of weed and shell, wreckage of ship and sail, blocks, planks, spars, boxes, flat corks, strange woods -all the flotsam of the wave is there-flung 
together in an odd confusion. And as one wanders along the sands the eye picks out things more personal to humanity - a glore, a woman's hat, a faded photograph, a wreath of orange blossoms, a Japanese book printed on rice paper and on the fly-leaf in faded script a name, "Thérèse Marcou." Tales of the sea too simple for comment, perhaps. Yes, and with them, sometimes, horrors too obvious to be mistaken. A few years ago on the. New Jersey coast the waves washed up a French kid boot-a woman's boot buttoned tightly-and within it a foot cut off at the top of the leather as though by the clean blow of an axe.

A deed of violence! Yes; but the sea has witnessed many of them. To-day a battleship goes down and from her a thousand bubbling cries rise skyward; yesterday the sea water's crept into the heart of Mont Pelée and the overwhelming of St. Pierre followed; to-morrow perhaps some South Sea island or Indian shore will be inundated by a tidal ware and whole villages destroyed. But what cares the sea! The bright waves continue to travel landward, they fling the broken remnants on the shore, the very dust of disaster is shaken from the surface. The passing of light, of shade, of color, of life, are all one to the sea. 


\section{CHAPTER VII}

\section{THE WAVE'S TOOTH}

Cliffs of granite that stretch up and down the coast, capes of rock that here and there push their prows out into the ocean, shores of shingle and sandstone that forever shoulder the broken wave away-what a barrier they form against the sea! The mighty wall, with a foundation far beneath the tide and an elevation far above it, how impossible of conquest it seems! Serene it stands with perpendicular face turned seaward as though defiant of the elements. The pines and birches grow on its top; below the verge in the crannies of the rock cling sumach and alder, interspersed with samphire, sea pinks, field daisies, goldenrod, or perhaps only moss with green and yellow lichens; from its pinnacles the osprey watches the outstretelied waters; and along the narrow ledges the clamoring sea birds build their nests. The sense of security and permanence is omnipresent. We are prone to think that no wave could ever prevail against that tower- 
ing barrier. It is too strong, too high, too thick for sea-born hosts to eonquer.

And yet a hundred feet or more above the tide on the face-wall little vegetation grows, the unweathered surfaces show where immense blocks have recently loosened and fallen away, and down at the water's edge the shore is made up of great bowlders each weighing perhaps many tons. What is the signifieance of this? And why does the cliff, seen in profile, reveal a base that recedes and a top that projects out Blocks and boulders broken orer the wave? It is perhaps true that the barrier cannot be overcome by any sudden attack of the waves; no storm however fierce can surprise or break down the wall. But is it proof against continual assault, day in and day out, year in and year out? The blow of the wave may be fended off, foiled, thrown back; but the daily gnaw of the wave's tooth-what granite base can withstand that?

Not always is the eliff being beaten by great seas. If its foundation is sunk in very deep water the waves will flood in silently, without break or dash of crest. The bottom of the at cliff base. wave, meeting with no friction, travels as fast as the top; and being, like the base of a triangle, further forward than the top, it strikes the underlying foundation wall first. The re- 
The shallow shore

Friction of wave bases.

sult is a rebound and a shooting upward of the water into the apex of the wave-a dancing skyward of harmless jets. Even a heavy storm will not always throw waves against a cliff so situated. It is the most secure of the rock barriers, and centuries may elapse before such a wall is finally disintegrated and east into the sea.

The cliff with a shallow shore, shelving outward, fares much worse. The waves as they come in from the sea, moving in even succession, begin to feel a pull upon their bases as soon as the shallowing commences. The drag upon each wave retards the onward march of the columns, with the result that the forward waves move more slowly, and the ones that come after eatch up with them-close up the ranks as it were-and make the columns shorter and nearer together. As each wave moves up the shelving shore the friction becomes greater. The base is held back by the sea bottom and pushed back by the undertow running outward from the shore; while the top, being less retarded than the base, is by its own impetus driven ahead-pitehed violently forward. The climax is reached when the wave dashes itself to pieces against the cliff and falls in shattered foam among the shore bowlders. Immediately its broken fragments gather them- 
selves together and there is a recession of waters that runs down the shore and helps form the base of a new breaker, or else runs under the wave and out seaward in the undertow. This process of forming, breaking, striking, and receding is endlessly repeated; the shore is never Breaking and striting entirely free from it, the sea is never completely at rest. Even under the smooth glittering moonlit surface there is always the ground swell, the curve and fall on the beach, the wash downward of the broken waters.

The waves, that have been affirmed as seldom rising fifty feet from trough to crest in mid-ocean even in hurricane weather, reach to enormous heights when hurled against the shore. A heavy storm on a shelving coast will fling crests of spray up and over cliffs a hundred and fifty feet in height with apparently little effort. The whole wave does not go so high by any means; but the tremendous impetus put in the top by the forward motion of the wave, together with the force of the wind, hurls the crest far beyond its parent base. The usually cited illustration of this is Bell Light on the Scottish coast, which, though one hundred and fifteen feet above the sea, is often hidden in clouds of foam and spray. And, again, Eddystone Light from a structure sev-

Height of waves along rocky coasts. 
Impact of storm waves.

Destruction of islands.

enty-two feet in height was rebuilt in $187 \%$ to an altitude of one hundred and thirty-two feet to prevent the waves from riding over the top of the lantern.

The impact of such waves is estimated at a maximum of about seventeen tons to the square yard. The southern coast of England can be felt to tremble a mile back from the shore when a great gale is hurling waves against its cliffs; and the direct result of this battering and storming is easily computed. Dover Strait widens a yard or more each year, and Shakespeare Cliff has worn away nearly a mile in eighteen centuries. Water deep enough to float a ship is now running over what was once a village on a cliff at Weybourne, Suffolk; and what are now the shifting Goodwin Sands were, before the Norman Conquest, the broad acres of Earl Godwin the Saxon. The wear is going on to-day with no whit of energy abated. The island of Heligoland, with its cliffs two hundred feet high, has been bombarded by storm waves for many years and is doomed to destruction; and many low islands that now lie along our rocky coasts were once portions of the coast itself, but were beaten down, worn away, and finally cut off from the mainland by a flanking movement of the waves. 
The storm wave is, indeed, a powerful battering ram. And yet the greatest destruction along the coast hardly comes from the swiftsmiting crest. There is force in the blow, to be sure; but in the long account of time it is the wear on the cliff bases that finally topples the rock forward into the sea. Day and night at the foundation walls there is the gnaw of Gnaw of the wave's tooth the wave's tooth; winter frosts ereep into the eracks and veins of the upper rock wedging it away from the main body; heavy storms follow with their breakers flung high up the wall; and great blocks of granite are loosened, falling with a crash to the bottom of the eliff. This is the process that destroys. Sometimes it is temporarily stayed, clogged by its own débris; but there is always a clearing away for new action, a preparing for a new attack. The sea is never idle.

And yet water in itself has small power to cut or eat into rock. Where there is no motion there is no wear. Five hundred fathoms down the rocks may be honeycombed by gases, but they are not disintegrated by friction. It is only along the coast that destruction goes rapidly forward. For though sea water has more or less grit in it that gives it a rasping edge, its real destructive power at the cliff base lies

The gril in sca water.
Wear upon cliff walls. 
IVave motion along shorcs.
Bowlders at the cliff bone. in the stones and sands it can more, drive before it, drag about from point to point, push into gravel pens, and whirl around and out and along the smooth ledges again.

This is all helped on by the manner in which the incoming waves usually strike the shore. It is seldom that they come "head on." More often they advance at an angle with a side thrust, a diagonal rub, for some length along the rock bases. Pebbles, shells, and round bowlders are swept along in swift procession, or are dropped momentarily into shallow beds by the loss of wave motion, only to be caught up again by the wave following after. In any event the grating process goes on, and in time both rock base and battering bowlder are the losers.

When the bowlder blocks first fall into the sea at the base of the cliff they perhaps lie there for years and, in measure, protect the cliff by warding off the waves. Gradually the rough edges are worn away so that they are more easily rolled. Sea weeds gather about them-weeds having bladders like pea pods that hold air and buoy up the stones, making them more transportable. Barnacles and limpets grow in among the weeds and make an outer armor that partly protects the stones themselves. When a win- 
ter storm comes the waves lift them and drive them landward with great force. Countless smaller bowlders carrying their modicum of fronds that hang down like fringes, are driven against them, the sands sweep around and over them, sea shells cut them, the shoek against the cliff walls breaks them. After a time the proteeting sea weed is torn from them, they grow ronnder, smaller, and are more easily driven with the waves. Finally they are all ground down to gravel and sand and flung along the beaches in a shower or carried seaward by the undertow.

Not one but millions of bowlder blocks along the rocky shores are, year by year, going through this process of disintegration. If the bloek happens to be a hard piece of stone it will last for a long time, and, while being slowly ground to sand, will work destruction to the things that grind. With a semi-human instinet it turns its flint edge against the softest piece of the opposing roek and works on that first-or at least it so appears judging from results. For everywhere on bowlder and eliff the wear is uneven. Soft parts of cliff uorn The wall presents a gnawed appearance, is hollowed out in spots, scooped in segments and half-cireles, eaten through at the back, probed along seams and ledges, scoured smooth in ba-

Fate of the bowlders. first. 
Spouting horns.

Rock grottoes.

sins and pot holes. In addition to stone weapons every swash of the wave may drive a long tongue of water up an open vein in the rockstrata of the shore until, after years of churning, a hole is worn through at the far end and a souffleur or "spouting horn" flings a line of white spray high into the sunlight with every pulsation of the surf. Once the passage is worn through it begins to widen. Eventually it may cut off that portion of the shore, and thus by isolating it, compass its fall more speedily.

Beneath the sea at the cliff's base where there is the constant pound of bowlders, sometimes a smooth circle in the rock is worn. In this circle gravel and stones are flung around with a swing like pebbles in a glacier pot. And with a similar erosive effect. It may take centuries of this grinding and working under the water to produce a marked effect; but eventually there is a grotto formed, and at low tide the entrance is perhaps apparent. In and out through this entrance the waves keep dashing, further and further the grotto keeps receding as the fissures in the rock strata are pried open, deepened, widened into galleries. The softer portions of the rock erumble away, the harder portions at the sides remain intact, the unwashed portions at the top make a vaulted roof; and the deep- 
bayed ocean cave is the result. Year after year the waters widen the door and broaden the cave's boundaries; year after year the ware floods in and goes feeling with wet fingers along Ocean caves. the dark cold walls, touching here, reaching up there, and then recedes upon itself only to be followed by another wave.

Often it happens that these ocean cares have their entrances far below the water line and are never known to man. Little if any light penetrates to them, and only the seal pushes a murky head above the surface of the waters or flings himself at full length along the dripping Within the caves. ledges of slate. Often, again, the entrance is only a few feet beneath low tide, and may be entered by a swift plunge down and in and up. Strange the sight within such a eave, lighted as it is from beneath the surface. The swimmer who lifts a white arm out of water or clambers up for a moment upon a roeky platform to rest, is amazed at the blue light that dances weirdly up from below, and the bluer drops of water that fall from his finger tips. The whole basin seems like a liquid sapphire, and the stalactites hanging from the ragged ceiling gleam like pendants of amethyst.

It is not probable that the wear of the sea alone is responsible for the deep indentations colors. 
of various shores called fiords. They exist only

Fiords. along mountainous coasts as in Norway and Alaska, and are supposed to be caused by a subsidence of the land, which has allowed the sea to enter the valleys and creep up the flanks of the mountains. But no doubt the water is responsible for much modification of the original subsidence. Once the sea gains a grinding space it is not easily persuaded to cease work. The long fiords that run for many miles back into the rock are not stagnant. The tide floods them slowly because it has a push up hill; but the ebb is more destructive and carries with it seaward much loose débris. The tendency is always to widen and deepen the runway of the water.

Possibly the best example of the fiord is not the smaller indentation that marks the coast of

Victor

Hugo's Lysefiord. Maine and Nova Scotia; but Victor Hugo's LṬsefiord, which runs inland some twenty miles, and yet in places is not more than two thousand feet in width. Its walls are abrupt, being based below the water line a thousand feet and rising above the water line over three thousand feet. It is apparently a cleft in the rock, so narrow that the sunlight never touches parts of it, winds rarely reach down to it, and heat and cold are comparatively without effect upon 
it. With a roof over all it might pass for an ocean cave, formed by widening and deepening a rock fissure, were it not for its enormous length and depth.

Time and tide and the wave's tooth, what will they not accomplish! The ehanges they have wronght appear on every coast. Working along the line of least resistance, working with that diagonal thrust, the waves have earved out many a rock-bound bay and left projecting into the sea many a wedge-shaped promontory. The promontory perhaps stands for years, facing serenely seaward; but always growing a little sharper at its point. Erentually a fissure appears back from the point, the water creeps in, gnaws through, and separates the point from its parent body. In a few years there is a core of hard rock, a needle, a pinnacle, a lonely tower, standing in the sea. Winds and waves carre it into fantastic forms, its inaccessibility make it weird and mysterious; and presently it is ealled by the 'long-shore people the Devil's Pulpit or Satan's Nose or The Old Man of the Sea. For many years this outlier of the shore stands above the tides, growing thinner and thinner each year, until perhaps during some violent winter storm it falls with a erash into the water. Immediately the waves begin clear-

Bays and promotories. how made.

along shore. 
Reefs and sunkien rocks.
Sands of the shore.

Pers and nicis of lwill.

ing away all trace of the accident. They smooth and seour and roll the broken fragments into deeper water until nothing but a stump of roek is left. Long years afterward the once lofty pinnaele appears on the sailing charts as a reef or sunken rock; and as you drive by it in a catboat you may notice a flattening of the water just there and a tangle of green sea weed that sways and rolls with each movement of the wave.

But is the sca always the gainer? Is there no compensation made to the land? What becomes of the fallen bloeks of stone-the disintegrated cliff? All the sands of the pocket beaches, of the bars, and spits, and shallow seabeds make answer. They themselves are but the granulated bowlders of the shore. As they are ground to sand and gravel the waves scatter them along the sickle-shaped beaches; or, quite as often, the currents lead them out to sea and heap them over sunken reefs. Drift upon drift they gather until after a long time-for the processes of nature are slowthey become a bar or neck of land called a shoal. At low tide this bar appears above the water-a dark, flat strip where shore-birds congregate and sea weeds eling. Eventually it lifts high enough to be above the tide, grows into a 
low sand barrier, is covered with shore grass, and makes a protection for a bay or sound back of it.

Frequently the building of sea barriers is helped by the deposit of streams. The rivers are continually carrying down immense quantities of silt and sediment. The bulk of this silt is carried only a few miles from shore beSea barfore it begins to settle to the bottom. The result is soon apparent in a bar or lido, made up of sand and river mud upon which vegetation grows and lends stability to the accumulating soil. With the sea once shut out a lagoon is formed reaching landward, and the tendency is for this lagoon to grow long grasses, gather vegetable and animal life to itself, and form small islands. The islands are often started by tangled bunches of sea weed, knit together by growing grasses, and made into a thick mat by various roots and weeds of the water. Frequently they are spongy in character and when walked upon bend like thin ice. And they may also drift about from place to place with the wind, lacking a foundation or anchorage. Such an island, some years ago, blew into the harbor of Duluth on Lake Superior during a storm, and was towed out by tugs sereral days later.

Lagoons and islands. 
The

Venetian lagoons.

Marsh

lands.

Bars and islands lost in storms.
When many of these islands are formed nature is disposed to unite them by strands and bridges of sea weed that thieken, knit and harden, until finally the whole area turns into a marsh covered with reeds and rushes. Venice with its river Brenta, its lido, and its lagoons, would no doubt have turned to sedge long ago, had it not been for the dredging of the eanals and the rise and fall of the one-foot tide. The marsh lands of Albemarle and Pamlieo sounds were made possible by such rivers as the Roanoke stretching sand strips parallel with the shore; and along the coasts of Maryland, Texas, and Brazil there are millions of acres of marshes formed in this same way. Eventually they beeome coastal plains and are inhabited by man.

This is all a winning from the sea by the land; and yet it must be admitted that it is not always a permanent accession. At times the sea rises in its might, overwhelms bars, islands, and marshes; and in a single day sets at naught the winning of years. Along the Louisiana shore in the Gulf of Mexico new lands are brought into existence from year to year, but others are being destroyed. Large islands have disappeared from there in recent times leaving only ugly reefs behind. Tree stumps that onee formed part 
of the great swamp forests of Louisiana are now found beneatl the Gulf waters; and the cypresses of Point Chicot, far out at sea, stand like spectres in the midst of a watery plain. The LouisThen, too, bayous have been ripped open by iana coast. great waves; and new channels have been cut here and there by the tides. Creole Pass, six hundred feet wide to-day, was not on the chart twenty-five years ago. It was born in a storm. At the same time perhaps a group of islands, a marsh or a belt of swamp, passed out-disappeared.

Give and take is the story of the shore. The tides creep in bays and harbors doing little damage, but they suck out down long inclines dragging with them sand and mud; on the contrary, the storm waves ride in with wear and wash but go out in broken undertow. The rock grinds down to sand and that is loss; but the sand comes back eventually to the dunes and that is gain. The return of the sands is made possible by the storm waves that rake and drag the shallow sea bottoms for many miles off shore. In the rush of water across the spits and the bars, the sands are caught up very much as light snow by winter winds, are hurried coastward, and flung in long beds and banks on the beaches. Layer upon layer they are heaped

Give and take of land and sea.
Return of the sands from the sea. 
on the shore, above the tide line, over the shells, over the kelp, over the vanishing wrecks of ships.

Drift of

In a few days perhaps these tons and tons sands. of newly-arrived sands have dried out in the sun, and when the cool sea breezes blow inland to take the place of the vacuum left by the rising heated air of the coast, the sands begin to move. Backward from the sea they drive and drift; but they do not go far before meeting with obstructions. It may be only a piece of timber or a clump of bushes; but in either case when once a pause is made, once an obstacle bars the way, the sand bank begins to grow like the snow bank. The sand drifts up and over, dropping at the back, so that there is a continual aceumulation in the rear; while grasses seem to spring up and pin down what is already Sanddunes. gathered. And so perhaps, after many years, there is a row of sand hills or dunes stretching along the beach, thinly covered with a long, wiry grass that holds them in shape like a net.

The dunes are barriers against the sea and very effective ones at that. As sand they are more indestruetible than they ever were as rock. The hard surviving kernels of the stone they are usually of uniform size and pack together 
like ball-snow, making a flat, smooth face that the water does not readily fraeture. The blow of the wave falling on the beach presses the sands more tightly together, but does not necessarily disintegrate them; the swash of the breaker at the foot of the dunes rolls the surface sands about and sometimes earries them away, but not so fast as they aceumulate. The tendeney is to move the dunes landward and the beaches seaward. Thus nature thinks to make up for the loss of the cliff by extending the gain of the shore. With things inanimate, as well as with living species, there is an apparent attempt to maintain the status quo. Change Maintaining the status quo. is continuous, unceasing; but the law of compensation sees to it that there is no final loss. Sea and land seem continually at warfare, but the result is merely an exchange of possessions.

For the dunes are by no means invulnerable to the sea. Pieced out by human aid in building connecting dykes aeross inlets they last perhaps for deeades, protecting such a back-coumtry as Holland, and allowing towns and villages with surrounding farm lands to exist below the level of the sea; but when violent storms come dykes and dunes sometimes go down before the waves, and great destruction follows. The Zuider Zee was thus made from a shallow lake

Dunes 48 sea
barriers. 
Inundations from the North Sea.

Travel of the sand dunes.

Destruction of villoges by sand. into an arm of the North Sea. Inundations along the Dutch coast have been frequent_at one time destroying a hundred thousand lives, at another submerging seventy-two villages. And always creating new water ways. It was not until the sixteenth century that the dykes were so firmly constructed that the sea was finally barred out from the northern Netherlands.

Nor are the dunes always stationary, even where free from the worry of the wares. The sands are uneasy and keep traveling with the wind, as the wind blows. Given a current of air and a free passage-way, and they immediately go winding like a golden snake, pouring themselves upon some newly-formed mound, which presently lifts into a dune. Where the coast is very bare, quite unprotected by heavy grasses, as along the Cape Cod portion of the Massachusetts shore, the dunes are continually blowing away-changing like a kaleidoscope into something new and strange every few months. And in some places they have proved as destructive to property as the waves. Lége, a village near Bordeaux, has had its church moved and rebuilt three times in modern days; and much of the village has been destroyed by the inundating sands. Other villages along the coast have had similar experi- 
ences. In open untimbered places the drift has been almost inconceivable. There are sand hills on the Chihuahua desert that have become mountains in height, yet are continually drifting to leeward with the wind. And that the vast sands of Sahara were originally blown inward from the western sea shore is not such a wild conjecture. All things are possible in the realm of nature.

But whatever compensation there may be in sand piled along beach and dune and desert, howerer this may atone for the loss of the cliffs, it does not stay the destruction. That constant fret at the edge of land and sea goes on forever. Century after century running into unknown ages there have been the rub of the wave, the grind of sand and gravel, the pound of surge, and the swish of high-flung spray. Beautiful is the sea in all its movements, never more beautiful than when tossing and turning at the foot of the eliff; but in the end the moving glittering sand proves diamond-edged; and the smooth wave, so like a tiger's paw in its velvety touch, shows the sharp claw beneath. A lover moaning at the feet of the Earth-such was the Sea in ancient fable. Yes; but his kisses have worn her away, and his love is the passion that consumes and destroys.

Sands of

Sahara.

The sea at foot of the cliff.
The tiger's pow and the lover's kiss. 


\section{CHAPTER VIII}

\section{SOUNDING SHORES}

Footprints of the sea.

Dover Cliff.

Sondwich beach.
Along the shore where the restless pacing of waves never ceases, only there are the footprints of the sea. The crescent beaches, the jagged coasts of honeycombed slate, the defiles cut through granite, the channel ways leading into lagoons and harbors-these are the blazed trails of the waves. Destruction follows along them; and yet, as we have seen, the sea sometimes builds up as well as pulls down. Since Roman days she has harried and worn Dover Cliff, scattering its sands far and wide; but during the intervening years, from other sources, she has built up Sandwich beach and turned its one-time harbor into dunes and meadows.

The sea began to slip away from the old Cinque port many centuries ago. When the cast wind blew across the North Sea, and the waves rolled over Goodwin Sands, perhaps parts of that shifting bed were carried inland and heaped upon the Kentish beach; when the west wind blew perhaps it dried the sands and then banked them into dunes that step by step fought 160 
their way seaward. However it was, the land gained on the sea, the old town with its Norman church, its walls of flint and crumbled moat, was deserted by its ally; and to-day it stands two miles inland-a town without a harbor, a port without ships. Small craft still creep along the muddy Stour and anchor at the Fishers' Gate, but not since Plantagenet days have the waves paced up and down by the ancient walls.

From the village going down to the beach one crosses meadows that look now as perhaps did Goodwin Sands in the days of the Saxon. After a mile or more across these flat lands the dunes appear. They are tumbled-and-tossed dunes that drift little to-day because held firm by beach grasses; but in form they roli and dip and hollow like a cross-cut sea, and seem to have been formed in some convulsion of the coast. The convulsion, howerer, nerer took place. The formation is due solely to the winds that seem forever whirling and twisting along this coast. It was possibly the very irregularity of these dunes and their abundance of "hazards" that led the St. George's Club to occupy them as a golf course. It is known to-day as the "champion course," and is often spoken

The old toun of sanduich.

Across the meadou's.

The St. George's golf course. of as "the links by the sea." 
Far down at the foot of the dunes are the waves. When the tide is at flood the golfer, if he will, may look out upon the gray water where dingy sails of ships melt into thick misty air, where Channel fishing-boats bob up and down

Gray

waters.

A wreck on Goodwin Sands.

in the choppy waves, and where coal-burning steamers, coming up Dover way with the wind, are smothered in their own smoke-dirty blackhulled steamers that wallow and stagger through the gray-yellow water as though top heavy. It is a wonderful sea, at times a terrible sea, a sea that has been often strewn with wrecks and is ever dreaded by the sailor. To-day perhaps it is tranquil enough but to-morrow it may be dashing high over Goodwin Sands, threatening the shipping in the Downs; and foaming up the dunes with caps of spray that leap and ride upon the winds like Valkyries. Not the depth of the water but its shallowness makes it dangerous. A ship driven in by a gale strikes upon the Sands, is lifted and pounded by the come-and-go of each wave, is strained and wrenched from stem to rudder post; until at last with opened seams and broken back she rolls a helpless wreck. Backward and forward she tosses as the waves come and go-waves that are all fury and swing over the hulk with a savage swish, tearing at blocks and sheets and 
shrouds, twisting planks and bulwarks and stanchions. Up into the rigging the white erests reach, striking and wrenching at the sailors clinging there, until one by one, exA $n$ old, old hausted by cold and bewildered with spray, the men are shaken loose and drop into the scething foam. It is an old old story along this coast. Everyone between Margate and Dover has the same tale to tell.

When the tide is at ebb the dunes are nearly a mile from the sea. A great stretch of wet, glittering sand, flat as a floor, reaches down to the water's edge. Here and there are shallow pools where shore birds wade and the images of shrimpers and bait-diggers, seen in reflection, look stilted and uncanny as though elongated by mirage. A long line of black kelp stretches where the last high tide washed, shells and blue flints are scattered everywhere, ribs of wrecked schooners push up like fire-eaten stumps from the sand. As you move down toward the water the footing grows less secure, the sands become muddier, more grimy, blackish, a half submerged flat spreads out; and at an indefinable edge there is the break of the The half submerged flat.

The stretch of $u$ et beach. wave-a greenish-gray wave with a foam upon it like yellow cream.

It is not a lovable shore. There is nothing 
gentle or charming or winning about it. But the reach of it commands respect. And, too, the elements of land, sea, and sky are here reduced to their simplest terms. Color is a halftone made up of green and yellow, quite abso-

A gray along shore.

Somber coloring of North Sea.

The Scottrsh coast. lute in its harmony; the air is a thick veiling which unites everything; the light is muffled, strained through clouds, grayed by moisture. $M$ ist and cloud mingle with the smoke of commerce to complete the picturesque if sad monotone.

Yet the leaden skies that so often hang over these English waters are depressing; and, for all the strength of their somber coloring the coasts are a bit mournful. The North Sea in no part of it shows nature in her most entrancing moods. Up under the rocky edge of Sutherland, the skies are clearer but the water little brighter. It is usually steel-blue like that of the Black Sea. The old red sandstone turns dark at the water's edge, the beaches have gray lusterless sands packed in about the blackened stumps of rocks, and the sea weed is blackish, too. And almost always an uneasy waterchoppy waves, waves that are forever slapping the cliff walls, or else eddying currents that go gurgling through rock fissures and whirl about sunken reefs. At night the rocky coast becomes 
dark, forbidding, sepulchral with the sound of the sea.

"The nightmared ocean murmurs and yearns Welters and swashes and tosses and turns And the dreary black sea weed lolls and wags; Only a moan through the black clefts blown With sobs in the rifts where the coarse kelp shifts, Falling and lifting, tossing and drifting,

And under all a deep dull roar

Dying and swelling forever more-_."

It is all so very different along the tropic shores of the Pacific or the Atlantic, where fog and mist are seldom seen and cold is never known, where commerce has not defiled the waters nor manufactures blackened the blue firmament. On the coasts of Central Americato go no further seaward-there are miles and miles of beaches that have no name nor history and have been trodden only by Indian feet. Wonderful beaches they are, dazzling in light and color! All the glitter of the shore is theirs -sands of quartz and coral flashing in their whiteness, sands of peroxide of iron and flakes of mica, mosaic sands with strata of carnelian, obsidian, and agate. And here, too, is the shatThe glitter and itier. tered and outworn life of the sea, shells of American beachics. of the shore. pearl in countless numbers, ribbons and fronds 
and Gulf weed from reef and shallow, jelly fish, star fish, sea-porcupine, sea-turtle-all the flora and fauna of the Gulf and beyond. But seldom a relic or a trace of humanity. No wreck, no broken boat, no message in a bottle finds its way here. Nature still holds a sway

Singing sands.

The crescent beach. as undisputed as when the Spanish conquerors came. The terraced beach is perfect in its sweep, the sands as they crunch under the foot seem musical; and the blue waves that ride in with snowy crests break on the white shores with a sound like distant cathedral bells at evening.

Of all the beaches, in the tropics or elsewhere, perhaps the sickle-shaped or crescent beach is the most graceful in form. Especially is this true when the curve of the shore is emphasized by contrasting cliffs or rocky headlands near at hand. The abrupt perpendicular line seems necessary to bring out the winding horizontal line. And yet graceful as is this winding curving beach, it is perhaps not so impressive, not so strong, as the broader simpler shores. Along every coast, sometimes for hundreds of miles, are straight-away stretches where sea and shore seem to parallel each other in long vanishing lines that are nothing less than sublime in their reach. More often, how- 
ever, the beach has its marked irregularities such as sand spits thrust seaward, bays intersected, inlets cut through, depressions, elevations, steps, platforms, terraces, runways. The wind will carve a thousand fantastic shapes from banks of sand; the wearing waves will do no less for the beaches.

The fineness or coarseness of the shore sands is usually dependent upon the nearness of the cliffs. The closer to the rocks, the coarser will be the stone and gravel. The shorter quartercircle beaches are usually found in between the gaps of a rocky coast, and mingled with their sands will be found all sorts of pebbles-flints, agates, granites, porphyries. Here also will be found the shells of molluscs, the spiney casings of sea urchins, sprays of coral, claw of crab, tooth of shark, and conch of stromb. Winding ribbons of the deep, frail in form and color, are interwoven with long sea grasses; and caught in the meshes of these are pink star fish, gastropods lying lifeless in their gay-hued houses, and Portuguese men-of-war with iridescent float collapsed and tentacles frayed and torn. Both the flora and the fauna of the sea prefer the coarser beaches because they afford better feeding grounds, and at the same time greater protection. There is shelter to be had

The irregular shore.

Beaches of stone and gravel.

Strewn on the sands. 
Shell

beaches.

White rands.

about the rocks and within the pot holes and gravel pens, not only from the assaults of the wave but from the common enemy.

The beaches far removed from cliffs or rocky outcroppings are always made up of the finer sands, and are studded with shells of the foraminifera and polycystina. These smaller shells are not usually seen, except under the microscope, and a shore made up of them looks like an ordinary stretch of white sand. Yet they are far from white. Many of them lave gailystained lips, others are roofed with shells of pink, rose, blue, and yellow ; and all of them are surprising in their spirals and patterns. The beaches are heaped with these minute shells, and mingled with them are flashing crystals, black dots of magnetic iron, gray needles of flint, crushed fragments of mother-of-pearl. Taken together and perhaps by virtue of their varied colors, they form a beach of white sand which we tread under foot without a thoughta mosaic beach constructed of millions of tiny patterns which the water is always keeping clean and the sunlight is ever flashing into beauty.

The waves as they rise and break upon such a beach secm all crystalline clearness. During a storm, when they come in with sufficient force 
to stir the bottom muds, they may be clouded, sand-colored, yellowish; but the summer wave that breaks easily, runs up the beach in a flat Waves on push of water, and then sucks back under the foot of the new-coming wave, causes no discoloration of importance. The most graceful and the most perfect form of the breaker is shown when the water strikes the beach not at an angle but broadside. With such a wave the crest is not continuous across the whole breadth. On the contrary, there is a tendency in the crest to concentrate at the highest point, and the white lip of foam that rushes forward and down usually comes from a well-defined center. Nor is it often that a great lone wave comes in and breaks on the beach with a crash. The beach combers are generally very regular, of short length, and they break very much as white caps in mid-ocean, only more violently.

It is quite useless, howerer, to attempt a rule about breaking waves for they are far too variable. The wind determines the size, form, direction, and velocity; and the water but obeys the drive of the wind. Where the waves strike the beach diagonally there is a longer and apparently a more continuous breaking of the crest for some distance down the beach; and Forms of breaning uares. frequently, when the wind is blowing almost 
Have furrows.

Grace of water again.

Color of the wave.

parallel with the shore, the waves will curl and fall at their shore end like a furrow cast by a plow. Such beach combers will travel along the sands, sometimes for many miles, each white furrow having its successor marching at its heels and breaking along the shore in snowy sequence.

Very beautiful is the breaking wave! Water forms are always beautiful because of their elasticity, their pliability, their perfect abandon in movement. The reckless, careless, surging wave seems to have about it the grace of the unpremeditated. It is rhythmical and harmonious and yet, apparently, unrestrained by law or pattern. Each one that comes hurrying in from Newfoundland banks or African shore seems freighted with a message and falls breathless in its telling. It rises, curves, and curls, and as it bends downward a long bar of silver light flashes along its top. At this moment-the moment before the fall-the wave throws off its most beautiful light and color. The crest is bluish-white like a shadow cast upon snow, below it the thin transparent wedge of water shows a rare blue-green; and still lower the wave base shades into a darker blue. Color, light, sky reflection, and foaming crest are all mixed for a moment in a symphony of blue and 
white. Then with a hollow cataract roar the vision disappears in the shattered fragments that surge up the beach.

Quite as beautiful as the crested water that buckles and swells to its fall is the fallen water that, driven forward by its own impetus, finally spreads into round thin mirrors on the sands. It flattens and rolls into the most delightful rococo curves as the beaded edging widens here, narrows there, and yet holds its unity everywhere. What a mirror of Aphrodite it is, so clear, so limpid, so perfect in its glassy surface! Every marine painter has painted it, every poet has used it in metaphor or simile, every dreamer by the shore has watched it form and gleam and pass away; and yet it never palls, never wearies. The pale skies of morning, the rosy skies of evening, the The reflection of the water shield.

blue canopy, the bright cloud are reflected there; and by day or by night the sun, moon, and all the starry heavens are seen upon its surface. That watery shield flung flat upon the beach but to perish, how illustrative it is of nature's prodigality of beauty!

Alas! that the shining mirror is so quickly shattered. Each one is no sooner brought to perfection than it wavers, trembles, and then begins a precipitate retreat down the beach. 
Wave traceries in the sand.

Shore line in miniature.
Down, down it rushes, dragging with it sand, shells, and pebbles; and gathering its forces together disappears under the base of the new wave that is forming. Nothing is left of it but a ring of froth and the lines in the sand made by the retreating water. Very beautiful again are these lines-these wave traceries left for a few seconds on the beach. A glimpse of them between the come and go of the waters may reveal a whole shore line in miniature, with bays, creeks, cliffs, and beaches all in place. Higher up on the beach where the waves have worn deeper perhaps, there may be steps surrounding a half-circle suggestive of a Roman arena, or rolls of sand with valleys in between in very form of the waves themselves, or little fiords eut back into the dunes with steep banks or basins where the salt water stands in pools and sea weeds grow, and the drip of iron stain from near-by rocks colors the pool a bright orange.

These mirrors that come and go, the wet sands, the still ponds that lie in beach pockets, the pools that gather under the stern of some half-buried wreck or rest in some eatch-basin of the rocks, play with the sea itself an inportant part in the coloring of the shore. They are all reflectors of light; and light, falling as 
it does through a heary sea air, is strained and changed in the straining process, as we have already noted. At times when it is cold the air is tinged bluish-purple, and everything along the shore takes on a tint in correspondcnce therewith. The waves have a violet hue about them, the sands turn lilac, the rocks grow pallid with bluish shadows. At other times, especially at sunset when the sky overhead is flaming with crimson and scarlet, a reddish tone will spread along the beach, warming the dark cliff-rocks into a strange glow of life, and Light effects and shore rechanging the white dunes into hills of red porphyry. With the sky overcast and the light falling through filmy clouds the effect is lost in gray, gray shore and cliff and sea; and when a thin fog is lifting and the sun looks like a shining silver plate, the effect is milky white, blue-white as though seen through opal glass. The shore is very susceptible to influences of light; and any color-dull green, gas-blue, pale yellow, pure pink-may chance to dominate the scene.

And what of the golden coloring of moonlight that gilds the pinnacles of the cliffs, flashes Moonlight along the from the wet sands, and glitters along the tops of the falling breakers! Vastly impressive when the tide is at its ebb is this moonlight 
along the shore. Miles away down the exposed strand it reaches, and even beyond the lift of wreck and reef and island, it gleams on distant bays, on dripping slates and foam-washed Nocturnes. beaches. And the dark mysterious shadows that everywhere creep in to offset the gilded high lights are quite as fascinating. There is no more beautiful play of gold upon blue-black than the sea under moonlight; and no theme has so baffled the landscape painter as this subtle "nocturne" by the shore.

And yet quite as impressire in its way as light and color, even more moving emotionally, is the sound of the sea on the beach. The liq-

Sound of the sea on the beach. uid murmur of pouring water, the clink and tinkle of sands and shells, the deep undertone of the breakers make up a bar of music that cannot be set to words; and yet as it runs on, repeating the same sad note, how real it becomes! Was there ever such another dirge chanted by the elements!

"Listen! you hear the grating roar Of pebbles which the waves draw back and fling, At their return, up the high strand Begin and cease, and then again begin With tremulous cadence slow, and bring The eternal note of sadness in?"

What a note it is! The restless one who turns 
uneasily upon the pillow, and looks to the window to see the coming light, hears, even in the early morning hours, a shock upon the air, the roar of wide-spread London town; but indicative as it is of human want and misery, pathetic as it may be in its tale of unceasing labor, it has not half the sadness in it of the sounding shore. The pine needles overhead sing in the wind, and there are voices in the stirred leaves of the forest akin to those of the sea; but they are not quite the same. The great shut-in valleys of the Andes and the silent sweeps of Sahara with their hum of distance seem to suggest the roar of the ocean, as the sea shell which the child holds to its ear; but again it is only a suggestion. The sound of the surf has its own inimitable sadness.

Solemn and deep the reeurrent beat of the sea; and what is there in it that makes us think of Northern shores and Viking days? We somehow never associate the heavy surge with the southern seas, the coral reefs, or the shell-

strewn beaches. It has a hollow roar that speaks of eaves, fiords, maelstroms, rough seas, bleak coasts, great storms. Unconsciously we conjure up images of Norsemen in their strange-prowed boats, of Icelandic heroes, of Tristans and Iseults, of Balders and Brun-

The roar of London.

Other sounds in nature. 
Sumgestion of the sound.

Srienre ond sentiment.

W'hy are not both of thein true? hildes; and the passing away of the gods from the shores of the earth and the face of the waters. Solemn and deep the sound of the sea like the drums in Siegfried's Death March, telling of a glory that has ended, of an age and a race that are no more.

Faney! pure fancy! The sea tells no tales. Science ean explain the cause of the sound and analyze its notes to a nicety; and psychology can tell us just why and how our minds make a mountain out of the mole hill. Yes; but the romance is none the less real for that. It is only a elashing of water on the beach, if you please, but to those who have imagination and feeling it may be freighted with many meanings. The glamour of the world, the storm of passion, the stress of living, the peace of passing-songs of the soul, choral hymns, and funeral dirges-all are there. Like the strung strings of a harp each one of us may vibrate to a different note, but somewhere in the symphony of the sea there is the note that strikes its responsive ehord in each. Science may be true-indisputably so-but it does not follow therefrom that sentiment is false. 


\section{CHAP'TER IX}

\section{GARDENS OF THE SEA}

THE flowers of the sea are flowers more in appearance than in reality. Seen in masses through the clear water they look like beds of mountain pinks or fields of ferns or hill sides of wild asters, with moss and ice plant and cactus growths scattered between; but the likeness is superficial. The plants are very different from those known on the earth. They have no root, they absorb nothing from the soil, they require neither rain nor air, and some of them manage to exist with little or no light. There are no blossoming forms, no leaves, seldom any fruit; and while there are growths having a foothold on the bottom that rise up through a thousand feet of water to float ball-shaped tangles upon the surface, yet in form they are not at all like trees. The "trunk" that elimbs upward so many feet is no larger than one's finger and the bunch of weed at the surface that makes a sleeping place for the sea otter 
has nothing like the foliage of the maple or the blossom of the horse chestnut.

Indeed, the wonder is not that such odd plants grow in the sea, but that there should be plants there of any kind. The salts and other minerals of the water would seem sufficient in themselves to destroy, but they are not; absence of light and air would seem to be blighting, but

Conditions of growth.

Place of growth. it is not. The endeavor is not stifled. Nature with her marvellous resources adapts the plant to its habitat and, out of what might be thought desperate conditions, produces forms of usefulness and beauty. The growths are given claws like a bird's foot wherewith they cling to the rock; they have no branches but in their place long stems and fronds through which they absorb floating particles in the water; and they perpetuate their kind by budding, by division, by fertilization. In the economy of nature even the cold grottoes of the shore, and the bleak, muflled ledges of the deep shall not lie fallow, but bring forth increase that the species shall not die out and that no corner of the sea shall lack its garb of beauty.

The wealth of nature's resources, her sufficiency unto each and every crisis, never seem to fail. And how she moulds her ehildren to their varied dwelling places and fits them for their 
special struggle! How long would the stiff growths of the earth withstand the wrench of the wave and the ceaseless pelting of sand and Peculiar gravel along the beaches? Nature does not attempt their kind in the sea. There is nothing brittle about the weeds that live in the shallow waters along shore. Their long stems bend and stretch like rubber, and their rounded fronds and thongs are tough as leather. Add to this a glossy, slippery surface that offers little friction to the water, with air bladders or pods that keep the plant from being torn or dragged upon the bottom, and you have a growth that

Strength and fitress of sea weed 8 . rolls and sways in a heavy sea and comes to no more harm than the bending grass on the prairies.

And out of perfect adaptation to use comes beauty. What sinuous lines, what marvellous curves, the waves beat into these sea weeds! The ribbons and streamers and tresses swing and toss in the sea until the very grace of the wave itself is theirs. The forms of Chorda, of Lessonia, of Macrocystis are more pliable than whip eord, more willowy than willow, more wavy than the streaming hair of Mrænads or sea sirens. The commoner forms of wrack, of kelp, of tangle (Laminaria digitata), of what, for lack of a better name, is called "rock

Grace of sea weeds. 
Swaying rock weeds.

Patterned form in deep still walers.

Alga of the greater depths. weed" when rolled and heaped on the beach may not appear attractive; but in their ocean home, seen through a blue lens of water, they sway with each come and go of the wave with a grace quite wonderful and quite unparalleled. Even that wandering waif of the sea, the Gulf weed (Sargassum), drifting in the great Atlantic current, has a bend and a reel about it, as it slips down the back of a wave, that is almost as graceful as the flight of the petrel following after it.

And what of those plants far down in the sea gardens that never feel the push of waves, those plants that never move or are moved from age to age? Are they perhaps modeled upon the same pattern as their cousins near the shore? By no means. In the depths where no storm or wave ruffles the eternal serenity nature is free to expand; and there she grows plants of symmetrical designs with no fear of their accidental destruction. Wonderful forms she models - crimson weeds with plumey fronds, purple dulses with lace-like patterns, iridescent mosses with antlered branches. Countless alge, wing-shaped, threaded with lines, cupped and domed, starred and crossed and circled, are there. 
"In the wine-dark depths of the crystal, the gardens of Nereus

Coral and sea fan and tangle, the blooms and the palms of the ocean,

Stand in meadows and forests unchanging, unfading from decade to decade.":

For thousands upon thousands of miles under the surface, along every island and continent, stretch these wondrous growths of the sea. They were not made for us, they flourish where human eyes never see them, and many of them shrink when human hands touch them; but neither their life nor their beauty is in vain. Form and color were not cast in sensuous moulds especially to gratify the æsthetic taste of the human. They are, indeed, merely the outer manifestation of completeness, of fitness to an end; and it may be that plants were garbed with beauty to please a sub-conscious feeling of their own. We deny it. But it may be true, nevertheless.

Not everywhere in the sea do these gardens grow. It is assumed (perhaps erroneously) that the great depths are barren and that plant life goes out with the light of the sun. Certain it is that the bulk of the sea weeds-several thousand species-grow along shore in fifteen or twenty fathoms of water where the tempera-

Extent of the sea oardens.

Feeling in plants. along shore. 
A popular classification of sea weeds.

Green alga.

Blooms and net weeds ture is higher than in the depths, and the yellow sunlight penetrates to the bottom. As the shore shelves off into the sea the growths become smaller and smaller, finally disappearing entirely, so far as we know. In a very general way the descent seaward is marked by the color of the sea weeds; and a popular classification of them by color may be made, though it lacks scientific accuracy.

Along the shore, often in tide pools, rock basins and marsh inlets are the numerous groups and families of the class Chlorophycece or green alga. The color comes from the presence of chlorophyll in the cells, and the forms are small and complicated. The bright-green sea lettuce (Ulva), the iridescent white-banded Peacock's Tail (Padina pavonia), the fanshaped cladophora (Cladophora arcta), the green laver (Porphyra vulgaris), the sea bottle (Valonia ventricosa), with many moss-like, netted, filamental, hairy, spiny, cactus-formed plants, belong to this class. They are growths that need sunlight and are not usually found in deep water.

Still another class of sea plants, Cyanophycece, need warm sunlight and grow near the surface. In fact many of them grow on the top of the water and are known to us as water 
blooms, seums and net weeds. The color is blue-green from the presence of phycocyan, but this is subject to some marked exceptions. The name of the Red Sea was given because of the presence upon the surface of a red species of this class; and there are other red species that appear in the tropic seas. Blue-green is, however, the predominant hue of the Cyanophyceer. Many varieties of it that grow in salt Blue-green water remain quite unnoticed by us because of their diminutive size. Some of them even require a microscope for recognition.

In deeper water yet still along the beaches, clinging to cliff rocks and growing in stony shallows, are the brown alga that belong to the class Phceophycea. There are many orders in this group and some of the forms are the Brown alga. largest of the sea weeds. The giant kelp or "Devil's Apron" several hundred feet in length, the Macrocystis of the Pacific with its thousand feet of stem, the bulky Lessonia, the sea palm, and the sea-otter's cabbage belong to it; and in a different division are the wrack that shows on the rocks at low tide, the Gulf weed that gathers in the Sargasso Sea and makes breeding places for pelagic or deep-sea fishes, and many small and complex forms of rock weed. A large number of this group live in the 
cold waters bordering upon the arctic regions, though some of them are found in the tropics.

Further out in the ocean and deeper down than any others, clinging to rocks, banks, shells, wrecks, even other plants, are the red algo belonging to the class Rhodophycea or Floridea. Red alga. These are the most beautiful of all, not only in the brilliancy of their coloring, but in the delicacy of their forms and patterns. The majority of them are crimson, rose, or some other shade of red (though sometimes showing purple, yellow or violet), owing to the presence of phycoerythrin, a pigment that outbulks the chlorophyll and gives the reddish tinge. The forms are not large. Some have leaf-like branches and bear a protuberant fruit as tasteless as the apples of the Dead Sea shore; others are sawedged, rod-like, feathery, threaded, membranous, cartilaginous. All the corallines with bases stone-coated with lime, all the dulses with their blood-red colorings, all the gelatinous seamosses from which are made Irish moss, agaragar, and Japanese isinglass, belong here.

In addition to these large divisions there are many plants ungrouped and unclassified; and standing beside them along the hills and valleys of the ocean world are organisms that look vegetable and yet are animal. Time 
was when they were ealled "flower-animals" and "animal-plants," but the terms are obsoleseent. The division line between the flora and the fauna of the sea is not, however, too finely drawn, even at the present day. Many forms of the fauna favor the flower, the shrub, the branch; and yet these are but an outer guise-perhaps a disguise planned by nature whereby the animal lures prey within its reach. The likeness to the plant in such creatures as sea anemones, sponges and corai is eurions enough; but the real interest lies deeper. The organisms are marvels of design, wonders of The likeness to plants superficial. form and color. The care and wisdom of Creation are not more marked in planet and solar system than in the tiny dwellers in the ocean. The smallest specimen of globigerina or foraminifera-too small to be seen without the microseope-is moulded with perfectly radiating arms or symmetrical shell, and the sluggish form of the jelly fish is east in iris hues more perfect because more delicate than those of the Mariels of design and color. lily or the burnished dove. Indeed, the marvels never cease in "the world below the brine."

The rariety-what seems the infinity-of marine life is merely beginning to dawn upon us. The discovered species mount into the hundreds of thousands. As fast as they 
The variety of marine life.

One-celled life.

Minute organisms. become known they are duly named and classified. There are now nine or ten large branches with many classes and sub-classes which serve as pigeon holes for the distribution of all sea life. The classification is accurate enough perhaps but ever subject to revision owing to newly acquired information. The end is not yet. We are beyond Aristotle and Pliny, beyond Linnæus and Cuvier; but not beyond new discovery.

The simplest form of this animal life in the sea is found in the one-celled Protozoa. They are mostly creatures of microscopical size. The body is composed of protoplasm and, in classes like the foraminifera, covered with a chambered shell, or like the radiolaria encased in a capsule and spicules, or like the amœba not covered at all. They move by contractions of the body, or lash themselves along with cilia; and they absorb food, both animal and regetable, by surrounding it or engulfing it. Under the microscope the forms are remarkable in design because infinitely varied and complicated. Each one of them is modeled after its kind as though serving a special purpose in creation. But most of these minute organisms, though the gardens of the sea are filled with them, make slight appeal to the shore wanderer be- 
cause practically unseen. At times a stain upon a rock, a discoloration upon a frond of sea weed, may point to the presence of some stray colony; but usually not even that much sign is apparent.

Not so with the sponges of the branch Porifera. They are marked features of the seabottom because of their bulk, their wide diffusion, and above all their varied colors. Time was when they were considered plants, but they are now positively placed in the animal kingdom. They are many celled and have inhalent pores through which sea water is drawn, and minute animal life extracted therefrom. Their forms are irregular-a mere fibrous network, influenced as regards its shape by circumstances and species. There are several classes, in one of which the spicules are calcareous, and in another of which they are siliceous, horny, or glassy. To the latter class belong the glassrope sponges, the Venus flower basket and the Neptune's eup. The sponge of commerce is merely the dried skeleton of the animal with its color bleached or faded in process of drying. Alive and fastened to the roeks, their forms expanded and their tints showing in masses of light brown, yellow, red, or brilliant orange they make up a remarkable sea-flooring. And

Kinds and colors of sponges. 
Polyps, sen anemones, and corals.

Coral colorings.

Coral reefs and islands. yet there is intermingled with them life in other forms even more remarkable, even more beautiful in hue.

Nothing in the sea excels in delicacy and variety of color the polyps and the jelly fishes belonging to the large branch, Colenterata. All the tints that may be wrung from the spectrum are blended in sea anemones, coral, and Medusa. The sea anemone is attached by a stalk to a ledge or a rock, and the polyp within gathers food from the passing currents with tentacles that seem ceaselessly waving, clasping and unclasping. They resemble flowers (asters in particular), though they take many forms and put on patterned colors that are astonishing enough. Coral is produced by a similar if smaller polyp, living in a small cell of limestone made from his own secretions. The stony deposit is in all colors-orange, scarlet, purple, green-and in all forms-branched, fan-shaped, sprayed, arched, rounded. When the polyp dies he himself hardens into lime and adds to the structure he and his kind have reared. That structure in time often becomes the long coral reef or the coral island of the southern seas, with which everyone is more or less familiar.

The Medusce or jelly fishes are not attached 
but free floating members of this brancl. They are usually bell-shaped or mushroom-domed. with tentacles hanging down from underneath. In the great Cyanea arctica the diameter is fishes. often from three to five feet, and the tentacles trailing down and away behind are several fathoms in length. This species has the power of discharging from its tentacle cells the lasso, which poisons whatever it touches and originally gave the family the name of " sea-nettles." The majority of the jelly fish are not, however, so large and are quite harmless, leading a drifting, spineless, uneventful existence, swinging Sea-nettles. with the waves like a submerged soap-bubble, and showing always transparent hues of azure, saffron, rose, and opal.

There are many of the medusoid types, widely divergent in form and color, and each type admirably fitted for drifting, for assault and defence, and for food gathering. The Medusoid types. Portuguese man-of-war that looks like a delicate piece of Venetian glass, and the Venus girdle (Cestus) with its winding silver-andazure ribbon of a body are the members of the family usually illustrated in books and set forth as types; and yet in every sea there are hosts of these transparent creatures-curled, ringed, belted, living necklaces with long pendants, 
Living ribbons and necklaces.

Sen urchins.

Armor of the sen. urchins.

Star fishes. bands and borders with pale fringes, balls and domes of blue with violet streamers-quite as beautiful in their way. All of them are merely jelly fishes, cousins of the more common unfortunate that we find stranded on the beach after a storm.

On the sand beside the jelly fish are often found stray members of the branch Echinodermata. The round sea urchin with calcareous plated shell, armed with spines, and looking like a chestnut burr in all save color, is one of the best known of the family. Why he should be so peculiarly well-defended with armor and several thousand spines, is hard to discover. To escape trouble he burrows and hides in the sand, and has even the power of making pockets in the solid rock, where he lies protected from the motion of waves and the attacks of the enemy. He moves about by the aid of his spines and tentacles, eats anything he can find, and seems proof against being eaten; but no doubt he has an enemy that circumvents him sooner or later.

Almost any pool or rock basin along the coast will contain the five-pointed star fish which with the sea urchin is classed among the echinoderms. It has tentacles with sucker feet whereby it not only clings and walks but 
through which it breathes. And its different arms act like hands, enabling the animal to pry open and derour oysters, clams, mussels, and other shell fish with considerable ease. When it loses an arm another is immediately grown in its place; and, that there shall be no unnecessary waste, the lost arm, if so much as one-fifth of the disk attaches to it, will grow another body. Some of the species have from eight to thirty of these rays or spoke-like arms, all of them adjusted with the greatest nicety. The brittle stars are near relatives of the star fishes. The basket fish (so called from the basket-like appearance when the branched arms are drawn in) is the conspicuous example in the group. He walks on the tiptoes of his tentacles and closes up when touched.

The crinoids are cup-shaped or lily-like echinoderms. They are anchored fast by a stalk, much like an animal tethered to a peg in the ground; and they feed in a circle about their anchorage. Some of the family look like a star at the end of a fairy's wand, but the majority of them are more like a flower on a tall stem. From this resemblance comes the common designation of "sea lilies" for the living species, and "stone lilies" for the fossil forms. Like many another species of echino- 
derms they drop their feathery tentacles at

Holothurians.

$\operatorname{sen}(\pi-$ cumbers.

Shell fish.

will and apparently without any lasting injury. The holothurians go beyond the star fishes in the matter of dismemberment for they break up into a dozen different pieces when occasion requires. They have a body somewliat like the sea worms, and might be put in the class with them were it not for their spicules and tentacles. There is no shell, but in its place a tough leathery skin. A long bottle-shape has given to one of the group the name of "sea cucumber," and sometimes (but erroncously) "sea slug." When seen in their habitat, say the Florida coast, their colors are most attractive. In China they are sought for food, and when prepared for the trade make the well-known "trepang."

The molluses come under the popular designation of "shell fish" and mean to the lay mind primarily the oysters and clams of eommerce; but the class is a large one and has great variety. It embraces some twenty thousand extinct species and as many more of the living species. Every sea has its quota and every shore has its shell-lined beach. The shell is perhaps the most interesting part of the animal to the casual observer. It is usually made of lime, is opaque; and within has a surface 
that is glassy, porcelain-like, or pearly. The contours are always graceful; and along the inner walls the undulations of the shell surface produce the most beautiful of all opalescent hues.

The univalves, as distinguished from the bivalves, have the single spiral shell. The spiral is made up of mounting rings that usually turn to the right. There are many of these gastroUnivalres and $b i$ valres. pods, but the great rose-colored stromb, called a "conch" or a "queen conch," is the most striking of the types. In poetry and painting it is the "wreathed horn" of Triton; and in prosaic every-day life aboard sailing vessels it is still used as a signal-call and a fog horn. The bivalves have two shells connected by a hinge and ligament; and that is the weak point in their construction. The star fishes, drum oysters, fishes, drills, crabs, oyster eatchers (not to mention human beings) pry them open and destroy them by millions. Nothing but rapid breeding keeps the family from extinction. And they are all beautiful in shell-form and eolor. The pearl oyster, the mussel, the seallop, the cockle do not exhaust the gamut of hivalve splendor. There are others of the family, seldom seen perhaps, that brought to the surface are glowing in cells of opal, topaz, and ame- 
C'ephalopods.
The persily nautilus. thystine-purple; and have lines that gracefully mimic sea waves in their rise and fall.

The cephalopods with their coiled shell have many extinct species, and many livin as remarkable for their ability to change their color at will as for the color itself; but only one of the living group has interest for those who are not scientists. This is the pearly nautilus, the sole modern representative of the Tetrabranchiates. It has become familiar in almost every household through the poem of Dr. Holmes, for it is

"The ship of pearl, which poets feign Sails the unshadowed main, The venturous bark that flings

On the sweet summer wind its purpled wings."

Pliny, centuries ago, wrote of it as stretching out a "membrane of marvelous thinness which acts as a sail spread out to the wind." With this sail it "makes its way along the deep, mimicking the appearance of a light Liburnian bark, while if anything chances to cause it alarm, in an instant it sinks to the botton." Whether it sails the sea or not is still a mooted question; but there is no doubt about its spiral shell with its different compartments in which the animal has successively lived, its "irised 
ceiling," its "sunless crypt," and its "shining archway."

In the same family with this romantic beauty of the sea is another cephalopod, a species without a shell belonging to the Dibranchiates, which interests not for his beauty like the nauThe tilus, but for his repellent look. This is the octopus. great polyp, the octopus. He is a monster of the deep and in body is known to be nine or ten fect in length by six feet in breadth, with tentacles thirty or forty feet in reach. He feeds upon anything living and in turn is fed upon by the sperm whale. It is, indeed, from the stomach of whales that evidence as to his size has been obtained. It is claimed by several writers that they have seen him in the life, but certainly the sight is a very rare one. All of the tribe have ink bags, which they discharge to cloud the water when attacked; and all are formidable antagonists fighting with both tooth Size and equipment of the octopus. and tentacle. In spite of a repellent look, which they must possess judging from the sinaller specimens in the aquariums, they are beautifully patterned with the most delicately blended reds, browns, violets, and pinks; and some of them have gold-rimmed telescopic eyes as soft and pretty as those of a gazelle.

The Crustacea represent one of the higher 
Crabs, lobsters and ocirnacles.

The hard shell, how iurmed.

Equipment for defense and attack. forms of sca life and one of the most widely distributed. There are ten thousand living species in the class, to be found in almost every sea; and they have almost every proportion from the microscopic to the gigantic. All the different varieties of crabs, lobsters, craw fish, shrimps, prawns, barnacles and acorn shells belong to it. The general name, Crustacea, comes from the hard calcareous casing which every member of the family wears. It is in kind a jointed armor, grown and colored by the outer skin, and cast off or "shed" at periods when the wearer has become too large for it. A new shell is speedily grown in its place, but until it is hardened the crustacean hides in sand or rock or weed. The equipment for defense and attack in this class is something extraordinary. Their bodies are constructed for bending, twisting, jumping; they have members for swimming, feet for walking, legs for burrowing, claws hooked and toothed for grasping and tearing, and jaws for grinding. In addition they are given antennce for touch, compound eyes for seeing, sense organs for smell and taste, and, finally, respiratory organs for either land or sea.

With such resources in attack and defense it is not surprising to find a bclligerent spirit. 
All the members of the large sub-class, Malacostraca, are carnivorous, eating anything they can find whether dead or alive. They are the true sea scavengers; and yet each crab in the sea is ever and always a fighter and a killer. They are no respecters of kind, killing and eating their weaker brothers without the slightest hesitancy; and being eaten in turn with no great struggle. The ealmness and ease with which one crab pulls another to pieces and devours him seems quite unparalleled among the animals of the land. And yet with all the savagery and ferocity of these cannibals they are given, not hideous and repulsive colors, but delicate hues of red, reddish-brown, steel-blue, and yellow.

And why not beautiful color in the sea life? If the birds of the air and the flowers of the field have it, why not the crecping things of the deep, and the alga of the beaches? Color is, Coine cf ser life. indeed, the sign of vitality, the symbol of life. Strength, exuberance, endurance go with it; and in this respect the sea is perhaps beyond the land. All its shallows are aglow with color. On the eastern coast of Mexico the sea gardens, seen through a water glass, look like autumntinged uplands in the days of Indian summer. Submerged in a blue-green atmosphere, and 
In the Mexican gulf.

Seen through a water glass.

Tropical fishes. lighted by the broken sunbeam that falls not straight but in a curved line like a spent rifle ball, the view becomes abnormal, astonishing, bewildering. For there one sees great tangles of olive-purple fucus and laminaria, lilac thickets of branching inadrepore, patches of " bloodflower" coral, beds of golden sponges, hillsides of crimson-tentacled anemones, valleys filled with swaying sea-feathers, all sown broadcast, scattered at haphazard in the bottom of the sea. There in every grotto and under every rock are scurrying squids and shrimps and scarlet crabs with pearl oysters and "chambered" nantiluses, star fish, sea lilies, sea urchins, barnacles, acorn shells, boring annelids, and winding sea worms. And there, also, with jelly fish gleaming in transparent opal, and chains of salpce pearly with phosphorescence, slowly move across the meadows and around the sea cliffs, myriads of shore fishes modeled in a thousand curious forms and decorated with gold, silver, and moss-agate colorings. Schools of blackbarred coral fishes (sometimes called "angel fishes") wind through the elumps of madrepore; trigger fishes (Balistes Carolinensis), with back fins that lock at the will of the possessors, wander aimlessly over the alga; parrot fishes with brilliant glancing colors browse 
along the reefs of coral; file fishes with tawny velvet skins circle the submerged rocks looking for barnacles.

Swifter moving, more alert, ever eager for prey are the red snappers with rose-red scales and blue-outlined fins, the pompanos traveling in vast schools like their cousins the mackerels, the cabrillas, with dark fins and barred flanks, beating along the bottom for small fish and crabs. And occasionally through these beautiful gardens there is a scattering in flight of all the smaller fishes as some lone, black-muzzled porpoise rushes across the scene or thrashes the green water into foam with the eagerness of a capture. The blue sliarks are there, too, though they spread less terror than the porpoises. Not even the saw fish-the shark-like bravo with six feet of saw-edged snout with which, it is said, he fights the whale-is so fearcompelling as the plunging, swift-traveling porpoise.

There is more or less terror in these sea gardens at all times. The chase and sudden death are constant happenings, for practically all the ocean dwellers are carnivorous. Each one kills and eats and in turn is killed and eaten. The sea lives upon itself, consuming and is consumed. It might be thought that such self-destruction

Sharks ana porpoises.

The chrase and the death. 
Changes in the sea life.

Testimony of the rocks.

could result only in extinction, annihilation. But no; the sea and its life have not declined in any way. Again, one might think from the enormous reproductive capacity of the ocean broods, from the millions of eggs of each herring, lobster, and oyster, that the sea would overflow with swarming hordes. But no; it has not gained or increased. Has it changed in any way since the foundations of the earth were laid down? Apparently not. The Cambrian, Ordovician, and Silurian rocks give testimony that many a deep sea group has not varied the slightest, has not evolved a scale or a joint in, let us say, millions of years. Such forms of life as the actinozoa, the brachiopods, the gastropods, the pteropods, the crustacea are the same to-day as in the earliest ages; and it is a fair inference that the medusa, the holothurians and other life not found in fossil form, because without shells, existed also in the Cambrian epoch.

This is quite in accord with nature's most obvious design. She is determined to maintain the slatus quo-the existing order of things. All her efforts are directed to that end. The sea itself is in a continual state of transition, and yet it remains the same. It changes by current, tide, and evaporation, changes by tempera- 
ture and density, changes by life and death; Nature and all that there may be no change. It de- $\begin{aligned} & \text { maint ine } \\ & \text { ing } \\ & \text { existing }\end{aligned}$ stroys that it may live, while apparently liring order. only that it may destroy. Erery part of it is volatilized, undergoes disintegration, seemingly passes away; and yet the whole endures, retaining its eternal youth and its eternal beauty. 


\section{CHAPTER X}

\section{DWELLERS IN THE DEEP}

Marine life in the great depths.

THE beautiful sea gardens of the Bermudas or the Bahamas, the upland meadows of the bench and the shallow, are not the only places where marine life flourishes. It was thought for many centuries that there was no other sea world than this, long believed that nothing could live out of the sunlight; and that the great depths were cold, barren, lifeless spaces. We calmly assumed that beyond our vision there could be nothing-a conclusion quite worthy of the King of Dahomey. But happily the dredgings of the Challenger have corrected us. There is life of many kinds in the great depths, and in abundance. Twenty thousand sea urchins brought up at one haul of the dredge would seem to suggest as much.

And are we quite right in still believing that there is no light in the ocean depths? Sunlight we feel reasonably sure is dissipated and lost in a hundred or more fathoms of water; but is there no other light? The dwellers in 202 
the depths have eyes-highly organized and rery sensitive eyes-and it is not believable that The problcm. of nature made them without purpose. That is quite contrary to her practice. And she sometimes eliminates a member if unused. The stream-fish in the waters of the Mammoth Care are blind, beeame blind by being plunged in continual darkness; but not so the majority of fish that live in the deep sea. From which it would seem that the dwellers in the ocean depths have eyes that are in continual useeyes that are perhaps adapted to another kind of light than sunlight.

It is explained by naturalists that there is phosphorescence or luminescence in the depths, that the fishes themselres possess it and flash it at will, and that their eyes are adapted to it. Very likely they can see by it to some extent; but is that the only light, is that sufficient to account for the marrellous telescopic eyes of some of the octopuses? We may be wrong about sunlight not penetrating to the great depths, never reaching beyond a hundred or more fathoms of water. We keep thinking of our sunlight, of the yellow, red and blue rays that make up white sunlight; but what of the far end of the spectrum-the $\mathrm{I}$ rays that were discovered only a few years ago? The dark ray pene-

How do the bottom dwellers see? 
The violet rijis.

Nther

lights in the deptris.

Lighting pouler. of luminescence. trates opaque substances and travels where the ordinary sunlight is turned back, reflected. Is it not possible that this same ray may reach through sea water to the lowest depths? And is it not further possible that the great watchcrystal eyes of, say, the lantern fishes were especially constructed to receive just that beam? Besides there may be still other lights-more lights than we have dreamt of in our philosophy -down there under the wave. The sperm whale that sees so indifferently upon the surface, goes down to the depths in his search for the octopus. By what light does he see his prey? Or does he scent the strong musk of the octopus and guide his course by that alone?*

As for the phosphorescence or luminescence with which many of the deep sea fishes are endowed, there is little known about either its extent or its use. It may hare no more illuminating power in the sea than a candle in a cave. And as a candle is used by a human being to prowl about with in the night, so the luminescence of the fish may be only an individual light that enables its possessor to go in and out of dark places. It is assumed by naturalists

* Mr. Charles H. Townsend, the director of the New York Aquarium, tells me it is doubtful if whales ever descend to very great depths. 
that the lamp-like contrivances at the end of the antennce in some fishes (notably the anglerfishes) are to enable the fish to see or dazzle prey; but it may be only a nervous manifestation indicative of fear, a defensive expedient to frighten enemies, or possibly an allurement for the opposite sex. The numerous hordes of small creatures that float on the sca surface and are known as "plankton" emit light, like the fireflies in the grass; but the reason for the luminescence at either the sea surface or the sea bottom is not easily determined.

It seems that many of the polyps, meduse, annelids, echinoderms, molluses and crustaceans have luminous species; and that among the bottom dwellers the lantern fishes are especially provided for in the matter of luminous glands in the head or tail, or perhaps in regular spots or photophores along the sides of the body. Others of the species have lights near the eyes, and others again have an electric light, as it were, suspended from a thin wire-like bracket projecting from the top of the head. All of these fishes are grotesque, somerhat distorted speeimens, being heavy of head and small of body, with exaggerated eyes, large mouths, and fang-like teeth. The bodies have not the graceful proportions of the surface

Plankton.

Lantern

fishes w'ith photophores.

Grotesque quality of deep sea fisher. 
Oceanic piressure.

Its effect on fishes.

fishes. Some species look telescoped (Argyropelecus), some are drawn out like lizards (Synodus fotens), some have an enormous back fin like the lancet fish (Alepisaurus ferox). The great majority of them seem abnormal in development. And that may be due to the peculiar circumstance of oceanic density.

Living twenty thousand feet under the sea the bottom fishes are, of course, subject to great pressure. The estimate has been made of one ton to the square inch for each one thousand fathoms. This, in the great depths, would mean four or fire tons to the square inch; and, while such pressure is equalized by being felt on all sides, it is not possible to conceire of a fish enduring it unless peculiarly and specially constructed for it. A bottle of champagne sent down a thousand fathoms may come up intact. cork and all; but the wine will be brackish. The pressure will drive the sea water through the cork. Multiply this pressure by five and what surface fish could withstand it? But the bottom dwellers have few bones. There is too much carbonic-acid gas down there to tolerate an extensire bony structure. The seales are thin, the skins velvety, the bodies eartilaginous. transparent, so soft and pliable that they are perhaps porous. They do not resist the squeeze 
but yield to it like jelly fishes. Yet for all the weight of water there is sufficient stability of structure to maintain distinet types; and in spite of it the sperm whale, with his great bulk, Peculiur disign of the deep goes down into the sea and comes back again to the surface none the worse for wear. The bottom dweller, however, does not usually fare so well as the whale when he comes to the surface. With the pressure removed from him lie becomes very limp, wanting in fibre, quite formless; and soon dies as a man might die who is transported six or eight miles skyward in a balloon.

All the deep sea fishes are enormous eaters. There being nothing to eat but the life about them they live upon each other. Every facility for killing and devouring is provided-luminescence to dazzle, swiftness and strength to overtake and overpower, knife-blade teeth for tearing, abnormally large jaws for crushing. Whatever the prey, or however large it may be, there is little trouble in swallowing it. The mouth yawns like a earern and the stomach distends to hold a body even larger than the swallower.

For defence or escape from pursuit these fishes have little more than the gloom of their abode, the mud into which some of them bur- 
Eipuipment for defense und fight.

The dismal existence.

Coloring of bolfom fishes

row and hide, and an inconspicuous back coloring to disguise them. The crabs and sea urchins are defended somewhat by thin shells and spines, the octopus by tentacles and inkbag, the medusce by poison; while some of the others are given power in flight, or breed to brave destruction. Just how they manage to exist and keep their numbers is something not well understood as yet. In fact the whole life down there seems somewhat dark, distorted, and dismal. But perhaps we are not the best judges of it. It has been said that to understand how an octopus feels about existence and happiness one would have to become an octopus.

And it may well be that there is some loveliness in the under-world of the violet sunbeam. For many of the dwellers there have great beauty of color. The gloom of the waters has not given them a pallor or deathlike hue, though a number of them have black or gray colorings or are black-backed and silver-scaled. There are red, pink, lilac, even bright green fishes, and fishes with scales of gold, topaz, and silver, living in the depths. All the crustaceans are as brightly hued in one water as another, the jelly fish are violet and opal, the sea cucumbers purple and green, the corals and sponges al- 
most any or all the colors of the rainbow. In fact the bottom of the sea is not so very different from the shallows as we have imagined. It has its peculiar conditions of light, tempera-

Peculier conditions in the sea beds. ture, and pressure, and in it have been placed a fauna, and possibly a flora, of especial fitness to meet those conditions; but otherwise it is substantially the same water and life as elsewhere.

The true ocean rovers are, however, the surface fishes that travel in schools; and these are perhaps more rapacious, more destructive, than their brethren in the pit. No doult all the life in the sea is plagned with a morbid hunger. The appetite in fishes seems never wanting; and complete digestion with some of them is only a matter of half an hour. Hence the slaughter that goes on unendingly. It is superinduced by hunger; and yet it is said that the bluefish, even when gorged, still kills for the pure love of killing. If so he is an exception. Nature sometimes produces a monstrosity, but with the majority of her creatures she enables them to kill only that they may eat and live.

But whatever the motive, whether for food or for frolic, these roving schools of fishes are certainly proficient in the fine art of murder. 
Herrings and porpoises.

Menhaden and their testruction.
They follow the prey like packs of wolves; and in turn are followed, band succeeding band, increasing in size as they decrease in numbers. The herrings eat the smaller fish, even their own young, they are harried by the bluefishes until a trail of blood stains the water, while following the bluefishes come the insatiate porpoises. Nothing saves the weaker ones but breed. Many thousands of eggs are spawned that a dozen or more may be hatched and brought to maturity. Billions are lost; yes, but millions survive. The herrings move on the sea in uncountable numbers, in banks that are miles in length and width, in windrows so vast that they perhaps keep passing one given point in unbroken succession for months at a time. Just so with the menhaden. A catch in a purse-net of half a million is not infrequent. Such numbers are sufficient to withstand all the ravages of the natural enemy. The bass, the haddock, and the pollock may kill to their heart's content, and still the menhaden will hold their own. They cannot, however, withstand the grcat destroyer-man. When whole shoals of them are caught at one fell swoop and dumped into the hold of a vessel to be tried out for oil, nothing but destruction to the species can result. That, however, does not seem 
to worry mankind any more than his prototype in slaughter, the bluefish. They neither of them cease from killing until there is nothing left to kill.

With the mackerels it is breed, again, that saves them from extinction. A single female will give forth at one spawning upward of two hundred thousand eggs. With such fecundity it is something of a wonder how the species is kept within limits. It has, indeed, been gravely estimated that were all the mackerel eggs that are spawned brought to maturity the whole sea in a short time would be a solid mass of immovable fish. But the mackerel has many enemies and his ranks are slashed by almost every fish in the sea. He trarels, with millions of his companions, in schools; and seeks by flight and dodging to escape the enemy. A rery beautiful sight it is to see them wheeling with a swift flash of their silver sides in the sunlight, sheering off from an attacking band. But usually the feint arails little. The sea wolres take toll and blood flows; but the mackerels, reering Movement of the and tacking, losing on the flanks and rear but ever closing up the broken lines, keep moving on.

The flying fish is a food fish, too, but not so plentiful as the herring or the mackerel. His 
The flying fish.

How he

flies.

Vibration and suiling. numbers are depleted by many destroyers, and besides he has an ugly habit of feeding upon his own kind. Cannibalism is not infrequent among all the sea fishes. And still, that the flying fish should not become extinet, nature provided for him a better expedient tran the mackerel's attempt to hide in the multitude of the school. She gave him abnormally long pectoral fins that act as wings wherewith he flies or sails through the air. There is still some question about the exact manner of the flight. Seen at a distance, the fish seems to throw himself out of the water with a serew-like churn or twist of his powerful tail; and once launched in the air to sail rather than to fly. The flight is maintained not usually for more than one or two hundred yards, and yet frequently so far as a quarter of a mile. In the air the fish seems to be somewhat wooden and apparently holds his body rigid, riding the breeze like a clay pigeon. When, however, he rises from under the fore foot of a ship, and one looks down upon him as he rises, the thin wing-like fins are seen to vibrate and to fan the air almost as swiftly as the wings of a humming bird. Whether the vibration is momentary or long-continued is difficult to determine; but it would seem that the wings propel the fish 
for a short distance, at least, as well as catch the wind like a flattened sail.

This flight of the flying fish often serves him in good stead, but it does not invariably furnish a safe exit from danger. The albicore or tunny travels as fast under the water as the fish in the air. Let the flier turn at a sharp angle and the albicore does likewise. The chase is thus often long-continued. The wings of the flier become weary. Perhaps he dips into the sea, striking his tail first, or plunges through the crest of a wave head first, for a second, and then is once more in the air. The contact with the water seems to renew his strength; and yet he wearies the second time sooner than the first. At last, after many descents and flights, perhaps the albicore leaps from the water and the remorseless jaw closes upon the exhausted flier in mid-air.

In addition to albicores, dolphins, bonitos, porpoises-all kinds of ocean racers-the flying fish has also enemies in the air. When his pursuers in the sea force him from the water, the birds of prey hawk at him from above. Between them both he is often sadly beset, and yet strangely enough his numbers do not seem to decrease. He holds his own in spite of adrersities.

Bird
encmies of the plying fish. 
The corywhene.

Swiftness of the porpoise.

Speed and power of the sea rovers.
The surface fishes, both those that flee and those that follow, are all agile enough. The twist and turn of the coryphene (popularly but erroneously called a "dolphin"), the speed of the albicore, the sharp gyration of the mackerel or the herring, the flight of the flying fish are the mere commonplaces of sea life. Even the lumbering, somewhat-stupid shark, who is more of a scavenger than a killer, will sometimes dart upward with the greatest swiftness, beheading a fish with a single snap as cleanly as a guillotine might do it. And as for the porpoises (properly dolphins) they are the embodiment of easy strength as they bowl along the surface like a string of hurdle jumpers, rising and plunging in perfect curves. They seem to move slowly and yet nothing in the sea moves swifter. They can run ahead of a fast-traveling steamer, and have little trouble in outrunning the waves upon the surface, which indicates a speed of, say, thirty miles an hour at least.

All of the sea rovers are constructed for speed. They are long, thin fish, large at the shoulder, and tapering away toward the tail. They have scales as smooth as mother-of-pearl, or skins like velvet that slip through the water with the least possible friction. The ease with which they glide when at play, the arrow-like 
swiftness with which they rush forward when frightened or chasing, are indicative of tremendous strength in proportion to size. Those who have caught tuna at Catalina, or tarpon along the Florida coast, or harpooned sword-fish off Block Island, have some idea of how great is that strength. A strong-swimming man, weighing, say, olle lundred and eighty pounds, can be "playel" and dragged ashore from the sea with less tackle, less effort, and less time Fitness to than a ten-pound sea bass. To be sure the fish has the advantage of being in his element; but how very well fitted he is to that element!

And how easily the tarpon twists and turns, plunges down the side of a reef, runs along a deep sea trough, or perhaps in play comes rushing to the surface and leaps ten feet into the air, completing a half-cirele of blazing silver! The Californian tunas when following flying fish often strike and catch the prey in mid-air, returning to the water, head first, in the most graceful arehes imaginable. And again the porpoises. As they travel across the seas in schools they clear the water in their plungings and no more; but they are capable of taking a high jump with the best of the jumpers, and when surrounded and frightened they leap over

Tarpons and tunas.

Jumping porpoises. 
Coloring of school fishes.

Protective colorings.

Changenble colorings. a boat and crew almost as readily as over the line of a net.

The school fishes are by no means of uniform coloring, and yet in a general way they are almost all of them alike in being blue-green or olive-colored on the backs, silvery on the sides, and whitish on the bellies. It has been said that this coloring was given them for conccalment and protection. The bird looking down upon them from above sees only the shading of their backs into the dark of the water; the shark looking up from beneath sees their light bellies and sides blending with the light coming from above. For a similar reason perhaps the flounder flattened in the sand was given a back that matches the sand as exactly as a tree toad's skin the branch he is resting upon. This gift of adaptation of color would seem something more than accident or coincidence. Many fish in the sea have tones and shades that conceal, and, what is more remarkable, many have the power of changing their colorings at will. This has becn long known, and recently quite conchusively proven, in the aquariums. Changing tlic backgrounds of the tanks has resulted in many fishes changing their hues to correspond.

But whatever the color, or for whatsoever purpose given, it is generally beautiful color. 
Sometimes a fish is not marked or barred or hned in an interesting way as, for instance, the grayish-black and dirty-white of the shark or the dull lead-colors of the pollock; but the school fishes, though they are brought forth in millions, have all of them tints of loveliness. What, for example, could be more superb in color than the back of the common mackerel! The green of the peacock's neek is not so brilliant nor the blue of the sea itself so intense. The silvery sides of the tarpon, made up of seales that are like thin plates of pearl, what again can equal them in lustre! And has there ever been known a more beautiful fish than the rarely-seen enryphene! $\mathrm{He}$ is a wonderwork of blue and gold, flashing in the sunlight with opalescent colorings, and under shadow changing into shades of silver. This is the so-called "dolphin" that poets have chosen to picture as growing more beautiful in coloring as he dies; but there is more poetry than truth in the figure. The fish changes hue, true enough, but he is never so beautiful as when alive in the water chasing the flying fish, his long dorsal fin of gold gleaming like an arrow of light on his blue-green back.

There are other inhabitants of the sea, wanderers that travel about the poles or around the

Beauty of the coryphene 
The cetaceans.

Many kinds of whales.

Dull coloring of whales equatorial belt, and yet are not fishes at all. The whales, for instance, are popularly considered as fishes whereas they are warm-blooded mammals. This is true of the porpoises, the grampuses, the narwhals, the killers, the black fishes. They are all cetaceans and live not in the depths but on the surface. In form they resemble the fishes, and have the fishes' tail wherewith they propel themselves; moreover, they are gregarious, traveling in schools for great distances, following the chase like the other sea rovers. But they are mammals, nevertheless. The whales are of many kinds and in popular nomenclature are right whales, blue, white, and gray whales, bowheads, hump-backs, fin-backs, sulphur-bottoms. The larger ones are toothless and live upon tiny erustaceans, molluses and jelly fish; others have rows of teeth and feed upon squid, herring and mackerel.

Taking them for all in all the cetaceans are not a pieturesque group. They are wonderfully equipped for the consumption of small sea life en masse (one rorqual perhaps swallowing thousands of herring at a single gulp) and have great adaptability to eireumstance; but in form they are odd, though not elumsy, and in color they are dull, sometimes quite dismally so. 
They have no scales to reflect opalescence like the fishes but in their place a blackish or dirtywhite skin that is interesting only for the ease with which it slips through the water. The larger members of the family are not often seen along the steamer lanes of to-day. Occasionally Scarcity of whales.

a black back will heave up at a distance, looking somewhat like an enormous water-soaked $\log$, and a spout of moisture-laden breath will go up from it; but the sight is an unusual one.

For the whales have their enemies and the tribe las not increased. The sword fish, unabashed by bulk, is said to drive headlong into the blubber of the great Mysticetus and killers (Orca gladiator) in bands tear him with their teeth almost as easily as a hermit crab disposes of a collapsed oyster. Almost everything in the sea has an enemy, and from high to low there is fierce struggle for life. Only a very few of the ocean rovers escape.

The turtle is one of the few. He seems to go his way in peace, moving slowly, never in a hurry, eating what he can get, and seeming to Enemics of the whale. have neither friend nor foe. On sea or land, in the depths or on the surface, he is always at home. His breathing apparatus is peculiar in its large expanse of lung, and he exists readily in eitler air or water. Sometimes for many

The $s e n$ turtle. 
Habits of the turtle.

The seals. hours he lies half-buried in the bottom mud, or floats sleepily on the surface with a round circle of back projecting above water, his head and flippers hanging down listlessly. Then for days he suns himself on the sandy beach of some sea island and becomes quite a land lubber. $\mathrm{He}$ is a famous swimmer making long journeys with ease, he can go for weeks without food of any sort; and he is sheathed in an armour that none of his sea fellows can break, and none, except possibly the sperm whale, attempts to swallow unbroken. By his equipment, his fugality, and his singular vitality he is famously fitted for endurance. And yet perhaps not more so than another ocean waifthe seal.

The fur seal of the Alaska coast and northward is the type though there are many species of the tribe-sea lions, sea leopards, and sea bears, with harp seals, ringed seals, saddle-back seals, bearded seals, ribbon seals, hooded seals. The ordinary fur seal is perhaps the best swimmer in the ocean. In strength and in swiftness he seems quite unparalleled. He travels almost as fast as a porpoise, and yet strange enough when born he eannot swim at all. Mr. Bullen has it that his mother takes him into the water and teaches him his first strokes. If so he 
proves an apt pupil and when, after several months, he leaves the rookery on the seal island where he was born, he sets out for the open sea quite alone and quite undismayed. There he cruises, hunts, plays, eats, sleeps-a true ocean wanderer. His fur and his fat keep him from any chill, and his tremendous agility and swiftness keep him supplied with squid and fish. His appetite is something phenomenalin captivity fifty or more pounds of fish being required daily by a single seal. After gorging himself he goes to sleep floating on his back with flippers folded, his head bobbing up and down upon the waves, as peacefully as upon a bed of roses. There occasionally a shark finds him and bites him through and through or a killer whale swallows him whole; but usually he is safe in the sea. It is only when he returns to the islands to breed that his great enemyman-makes havoc among his numbers. Not his flesh but his coat is wanted. With the exception of the pearl oyster he is about the only dweller in the oeean that is killed for his beauty.

All the life of the sea, beautiful or otherwise, destroys and is destroyed. Again comes up that seeming contradiction of purpose, that seeming paradox of life and death both being necessary

Birth and grouth of the fur seal.

Killed for his coat. 
All the sea life is destroyed.

Endurance of the type.

What lies beyond. parts of a plan. And once again the apparent inconsistency of beauty being given to creatures that are sent to destruction by the millions. Why the effort sinee it is to be so soon nullified? Why the beauty since it must so soon perish? Is there naught eoming out of sea travail that shall live and be glad forever?

Ah yes! the species endures, the type continues though the individual is lost. It is the come and go of countless individuals, each one having its day and passing on, that preserves the type, keeps the species active, virile, youthful, beautiful. The sea renews itself by change in every part. Life and death are but the processes of renewal. The units matter not, though they are not given over wholly to misery. There is a joy in life, an exaltation in being and living. The very struggle to maintain life proves it. There may be an even greater joy in death. Who shall say what lies beyond, what rests in store, for the humble dweller in the deep? The eye of gold, the scale of pearl, may appear again in newer splendor; the exuberant life may be renewed with even greater vitality. Who shall say? 


\section{CHAPTER XI}

\section{GRAY WINGS}

The sea wherein life first began is still the supporter of life. It feeds its own, sustains itself, and yet always has something left over for the dwellers upon the land. Sooner or later all of nature's children return to it, as desert animals troop by night to a pool in the waste. It is the source and from it directly or indirectly comes the food and drink that supply

The sea as the source the world. In its depths in unthinkable numbers are the ever-hungry fishes, along its coasts are the rapacious herds of seal and otter, and by its shores are the eagles gathered togetherthe birds of prey that follow the sea chase and are always in at the death.

If possible the bird is a little more voracious than the fish. The ordinary linnet or thrush of the garden is glutton enough in his absorption of insect life; but he has no such boundless appetite as the gull or the gannet. The sea birds seem impossible to satisfy. The brown pelican wheels for hours above a school of 

cans.

The plunger.

Cornoranis, shags. divers. The peli- out of water, but is manœuvred until he is

fishes, plunging head first with shut wings every few minutes, his huge bill snapping up luekless victims with great certainty. Once caught perhaps the fish is not instantly lifted quietly slipped into the large distensible pouch under the lower mandible. Then the head is tossed backward and the fish glides down the long throat. This performance may go on from dawn to dusk with few interruptions; and the next day the pursuit be taken up with renewed ardor. Success does not seem to weary him in the least. All the appliances to make fishing easy and profitable are freely bestowed by nature as though the pelican were a favored creation. The bill is not only sharp and hooked at the end, but is rough-edged so that no slippery specimen can wriggle out of it, the body is as tough as leather to withstand the blow upon the water in eontinuous plunging from above, the head and neck are museled to the last degree that the bill may move swiftly and unerringly. The whole machine works perfectly.

Always where the pelicans and gannets gather, perched along the shore and on the rocks, are hordes of cormorants, shags, diversbirds quite as clever in chasing fish under water as the pelican is in catching them from above. 
From the rocks they keep slipping into the sea every few minutes and dipping out of sight. They move slowly enough when swimming on the surface; but once under water their heads and necks stretch forward, their bodies seem to draw ont behind, and, propelled by foot and Chasing
fish undier vater. wing, they move with the ease, the swiftness, and the directness of submarine boats. The small fish cannot travel so fast nor can they by darting or turning elude pursuit. The shag usually comes to the surface with a squirmer in his filc-edged bill, and if the fish is not conveniently caught for swallowing, it is tossed in the air and caught anew by the beak of the skillful fisherman.

The penguin is said to be even more greedy than the shag-in fact a winged seal both in capacity for destruction and in general appearance. The bird's wings are, indeed, little more than flippers, members almost useless in the air; but once under water they beeome famous paddles that propel with alternate strokes at a great speed while the feet are used only as a rudder. The penguin spends most of its time at sen, in the winds and the waves of the Antaretic cirele, and is a deep sea diver of no mean ability. The auks, guillemots and puffins have similar habits and not dissimilar appearances. 
Long-

legged waders.

Flamingoes.

And they all live by the sea and follow the fisher's calling.

Beside these plungers and paddlers, there are long-legged waders that are continually patrolling the beaches or crossing the inlets or standing silently in the bays waiting for fish to pass. They have great curved necks that seem to draw out like telescopes, and bayonet bills that thrust, catch, and toss in the most expert manner. With appetites that relish almost everything, and crops that ean digest almost anything, they allow little to pass unseathed along their highways. Whaterer lives on or by the sea is grist for their mill. The beautiful rose-red flamingo, with the misshapen beak that would seem to handicap him in pursuit of prey, is one of the ablest of these hunters. The beak is little more than a box, the edges of which are guarded by lamellex, and the food (composed of the smaller salt water snails) is sifted through the box in a not very different manner from that in which the balænid whale strains sea life through his whalebone mesh. He wades the marshes, works with his head and bill "upside down," so that the upper mandible shovels through the bottom mud; and though ungainly he is far from being ill-fed. 
The scarlet ibis of the tropies and the blackand-white ibis of Egypt, though not classed with the flamingoes, have similar habits if not similar equipments. By the Egyptians the ibis The scarlet was held sacred because of its purity, and by the Hebrews it was thought "unelean"; but at the present day neither belief obtains, and many of the irreverent or unthinking eat the bird for a stork as opportunity offers.

The storks often travel far inland and yet are also found along the coast. Like the herons and bitterns they are eaters of the small fry of the sea, waders of the pools and marshes, people of long necks, legs, and bills. They are somewhat awkward as they more along the shore, and not too graceful when they fly; but they are not wanting in skillful handling of the neck and the bill. With them moving up and down the coasts at stated seasons in great Vshaped flocks are the cranes, perhaps the largest of all the waders. They, too, often go far inland; but with the storks and the herons they are essentially water birds and consider the shore their habitat. There they feed and there at odd seasons they indulge in strange dances. processions and races-antics more astonishing than a Moqui suake dance-accompanied by 
Shore birds.

cries and apparent eomments to be understood only by the erane family.

With the larger waders that flock by the sea and live upon the spawn of the waters are countless small birds with slim legs that trip along the beaches, running here and there over the wet sand, gathering what the last wave has brought in. They are usually called "snipe" by the unscientific, and "shore birds" by the inclusive; and true enough there are snipe among them. The stilts, the yellow-legs, and the willets might come into that eategory, but hardly the plovers and the curlews. But they are all more or less native to the shore and feed upon its lesser shell fish and worms. This is true of the still smaller birds, the turnstones that get their name from turning over stones in search of minute life, and the many rarieties

Tirnslunes and sind pipers. of sand pipers. The latter travel in flocks of from ten to twenty and spend their days scampering along the beaches. They are very alert, very energetic, very graceful; and their little thin legs move so fast at times that, like the spokes of a fast-traveling wheel, they cannot be seen. Ever the large eye and the large bill are seeking food. That seems the constant quest of all life in or by the sea.

Sometimes a small flock of these sand pipers, 
moving about on the wing in a fog, loses its shore line and drifts out to sea. It is not an unusual sight to see a half dozen of them five hundred miles from the coast, skimming along the surface, wheeling at sharp angles, and flashing the white of their under wing-feathers in the sun. When so seen they fly very rapidly, veer very often, and shift their course capriciously. It is always quite evident that they are lost, that they are beating about the waters as homing pigeons circle in the upper air when trying to orient themselves. Shipwrecked sailors in an open boat are hardly more helpless or more frightened.

Even more terror-stricken are the small land birds like the finches and warblers that singly or in pairs are sometimes seen far out on the ocean. By some error in night travel or by reason of fog or driving storm they lose their bearings and quickly get out of sight of land. When a ship with its masts is sighted they turn to it, no doubt, as to a tree in the desert; and Finches and warblers ir the shroinds. no noise or attempts at capture will drire them away for more than a few minutes. They return and cling wearily to the shrouds or ride on the eross-trees sitting in a ruffled and huddled heap with all jauntiness gone, and all song reduced to a saddened "cheep!"

Sand

pipers

lost at sea. 
Land birds at sca quite helpless.

Fiquipment of the true sea wanderer.
But the finches and warblers were never designed for the watery waste. Even the snipes and the sand pipers, with the whole tribe of beach and shore birds, were given no more than a limited equipment for ocean travel. They belong to the land. That is, they skirt the coast, beat along the breakers, perhaps cruise out to sea for a day; but they go back to the shore at night. They weary when the sun goes down, and like Noah's dove keep returning to what they regard as home. They must have a resting place for the sole of the foot.

Nature when she planned the bird life of the open sea builded better than that. Above all she planned for endurance-endurance of cold, wind, storm, hunger. And she eliminated the homing instinct and made many of the wave wanderers for solitude. Domesticity on the land for a few weeks was given them only for breeding purposes. For the rest of the time they were destined to be the true ocean waifs, traveling alone hither and yon, always songless and sometimes voiceless, with eyes seldom closing in sleep, and with wings seldom folding in rest.

The make-up of the sea bird is, indeed, remarkable and yet not extraordinary. It is no more than the expected; and is only another 
illustration of nature's fashioning things to an end and for a purpose. The body is usually very small-little more than a rack of bones and a wedge of sinews. An oily quality of the flesh, derived from a fish diet, and an outer layer of fat provide heat and enable the bird to live in the coldest climates. In addition there is a thick but light plumage that not only wards off cold and wet but adds to the buoyancy of the bird in the air as in the water. The muscling, in proportion to size, is prodigious. The wing museles, for instance, are developed to the last degree of elasticity, pliability and flexibility. It seems as though nothing could weary them. And the task imposed upon them is more than hereulean. The bird spends whole days, and even whole weeks, upon the wing, darting, soaring, wheeling, diving. The enormous wings with their motor of muscles behind them always seem suffieient unto erery emergency or requirement. They not only uphold the body for days at a time but they ride the breeze or gale, they tack, sail free, or dead ahead, as the bird wills; and with apparently as little effort as thistle down drifting with the wind.

Many of these ocean birds are gray-winged and gray-backed, though not all of them. The

Muscling and feathering ofusea birds. 
Gray coloring of sea birds.

Terns.

Gulls and their fight. gulls, terns and frigate birds are white or black or mixed; but the shearwaters, cape pigeons and petrels are gray-hued, sooty or blackish gray. Few, indeed, of the true sea birds have bright colors. The rose-hued tern is about the gayest of them all; and even he prefers to do his fishing in sight of the land, though by instinct and equipment he belongs to the sea. All the tern family are graceful birds in flight, darting, skimming, twisting in a way that has brought them the colloquial name of "seaswallows." In color the majority of them are gray on the back and white on the breast. They have a red foot, a sharp red bill, and a forked tail which rather marks them apart from the gulls, though in reality they are closely allied to the gull family. The shore with its schools of small fish is their hunting ground though sometimes a piece of wreck far out at sea or a serap of drifting wood will have a group of them oecupying it.

The gulls like the terns usually have white feathering below with gray backs; but the different species vary the monotony with whites and blacks. By virtue of long pointed wings they are extremely graceful in darting, plunging, and twisting, if somewhat heavy and awkward in straight-away flying. They are, how- 
ever, strong of wing and small of body and can stand the all-day flight without fatigue. Sometimes they are seen following ships long distances from the shore-following by day and disappearing at night, probably to rest on the water-but usually they prefer the confines of the shore. In the company of the shore birds they ply the trade of highwayman or sneakthief, robbing other birds of their catch, and plundering each other whenever possible. Every pelican, for instance, generally has a gull comHow gulls panion who sticks to him closer than a brother, and filches what he can from the pelican's quarry. When they must they take to small fishing, but they much prefer playing the scavenger or the thief. Yet the gull is a handsome bird in spite of his habits; and he is not to be despised as a sailer.

A more famous sailer, however, is the frigate bird. With the gulls he likes the region along shore; but he hunts out to sea long distances, and travels with less expenditure of energy than The frigate bircl. any member of the feathered tribe. It is impossible to imagine anything more graceful upon the wing than this bird. Along the Mexican coasts, as far south as Panama, he is frequently seen, at times perhaps a thousand feet above the earth, standing still like a box kite 
The wonderful suiler.

A sea pirate.

with no apparent wing motion; at other times he drifts or circles like the condor but with infinitely lighter wing; and, still at other times, when in pursuit of prey, he rises, falls, darts or follows like an arrow shot from a cedar bow. No matter where sits the wind or how strong it blows the expanded wings seem to gather it and convert it instantly into power. The wings are the things. Tremendously long they are (about six feet from tip to tip) for a bird no larger than a crow. The tail-the long forked tail that opens and shuts as the bird willsseems to be a necessary steering gear to such an expanse of sail. And he is a veritable Captain Kidd "as he sails, as he sails," a coast pirate flying the black flag (for there is not a white feather about him), and plundering whatever crosses his track. He is no fisherman so far as plunging or diving goes, he hates contact with the water and is seldom seen in it; but he is a keen watcher of the boobies, gulls, and terns, and when they have made a capture he does the best he can to take it away from them. And he usually succeeds for he is feared by all the coast tribe. It is said, too, that he plunders the nests of other birds, devours the young, and occasionally eats small turtles. When driven out to sea by hunger he does a 
curious kind of fishing among the flying fishes. $\mathrm{He}$ is the bird that follows the school and pounces upon the flier when he leares the water to avoid the jaw of the albicore. The swoop down of the bird and the dash upward, without touching the water, is a wonderful sight. The eagle and the hawk sometimes chase a wild duck from the sky to the water's brim, returning skyward on a swift parabola; but it is no such black thunder-bolt performance as the frigate bird exhibits.

All told the frigate bird has a bad reputation, though why he should be pilloried more than the other sea birds one is at loss to say. All birds are thieves, cut-throats, and murderers. That is their way of getting a living. The frigate bird is simply better endowed than the others, and instead of doing the eatching or dragging down, he prefers to rob the eatcher. Certainly he is admirably fitted for piracy. And though he does no week-long flights upon the water he is in make-up well fitted for the open ocean. The large untiring wing, the buoyant feathers, the spare body, the lonely disposition (for he is seldom seen in company, though he has been tamed and used as a message bearer between the islands in the Low Frigate bird catching fiying fish.

Frigate birl's bad reputation. Archipelago) were given him that he might

His fitness for long fights. 
The wandering albatross.

Flight feathers of the albatross.

travel the sea. Perhaps the only reasons why he is not seen there oftener are the scarcity of birds to fish for him, and his love of a rocky height rather than an uneasy wave for a resting place.

In this respect the albatross is perhaps a more perfect example of fitness to an environment. He is always a deep sea wanderer, is more at home in storm and wave and cold than in ealm; and, by instinct rather than preference, comes to land only for a brief breeding period. He is much larger than the frigate bird and not so trim and shapely in form; but his expanse of wing enables him to handle himself in a really marvellous manner. Rising from the water he flaps his wings awkwardly like a gull or a pelican; but once launched he wheels or turns or follows with seareely a motion of body, wing or tail. The wings are long and narrow, containing a greater number of flight feathers than those of any other bird, and certainly in flight they carry the albatross with wonderful ease. He follows a ship for days at a time (dropping away at night and returning in the morning) with never a motion of the wing, let the ship taek or sail free as it will. Only when there is a hasty descent for refuse cast overboard is there any perceptible wing ac- 
tion. Storms, squalls, head winds do not have the slightest effeet upon him. Commander His sailing Wilkes speaks of him as " resting as it were immovable in the storm," and many other observers offer similar statements. The flight is the perfection of aërial narigation.

The wandering albatross (Diomedea exulans) is rarely found north of the equator. He is devoted to the cold and storms of the Antarctic, and, if he is led toward the equator, it is only in pursuit of food. Like the gull he is a scarenger first and always, a sea vulture eating refuse. He follows ships for that purpose, has a nose like a buzzard, and either sees or scents ocean carrion, such as a dead whale, at very long distances. His liabits hardly make him a romantic bird, and yet he is beloved by the sailor, and has been made the subject of numerous poctic eulogies. And deservedly so. For he is a thing of beauty upon the wing as he rides the wind beside the traveling ship, and in the lonely portions of the ocean where he is seen, his white presence is always a welcome variety in the sea circle.

Some of the open-sea birds, whose doings are not so well known as those of the albatross, are said to be "strange" or "mysterious"; but the strangeness lies not so much with the birds

Where and how the albatross lives.
The tropic bird. 
His steering gear.

Cape jigrons ind whale birds.

as with our ignorance. The tropic bird is one of the suspects. He has a long narrow wing like that of the albatross and as a sailer can point dead in the eye of the wind with as little effort as any inhabitant of the air. As for his steering gear it is composed of only two long tail-feathers; but these seem sufficient to control the wide wings and work wonders in tacking, pitching, and angle darting. He travels alone, follows the ship, and at such distances from the shore as to preclude all possibility of his returning to land to rest. No doubt when weary he rests upon the waters like the albatross.

Smaller than the tropic birds and with just as little known about them, are the eape pigeons of the Southern Ocean; and, if possible, still rarer as a sight are the whale birds that oceasionally gather about sea carrion or ocean dereliets. The shearwaters that skim the surface like a skipping stone, belong to the same family of ocean travelers; and are seen swiftly wheeling, bounding, veering along almost every sea. They are powerful of wing and like the whale birds seem always in the air. Indeed, it is said of the latter that though always orer the sea they never touch it. But they have the webfoot and no doubt that foot knows its element. 
The sailors' tale of sea birds never alighting in the water is perhaps truer, comparatively, of the petrel-Wilson's petrel (Oceanites oceanicus) - than any other. If there is a wing Wilson's that never tires, that is capable of motion indefinitely, week in and week out, it is that of the petrel. The idea is not so impossible, not so fantastic, as seems at first blush. The human heart beats without a pause for seventy years; why not the petrel's wing for, say, seventy hours? It all depends upon the muscling. Everyone knows the stout fibre of the heart and why it does not grow weary; and yet the petrel's wing-and-breast museles are even more powerful after their kind. Just so with his brother, the stormy petrel (Procellaria pelagica), the bird known to sailors as "Mother Carey's Chicken." The "chicken" is, in size, no larger than a robin-the very smallest of all the web-footed birds. In color he is as grayblack or sooty as a chimney swallow, even to his legs, with the exception of some white on the wings and near the tail. He is seldom if ever seen resting on the sea, nor does he rest or sail upon the wing like the albatross. On the contrary, the wings are always moving, and the flight is never straight-away, but twisting, turning, gyrating. Again he is never seen high 
The fight of the petrel

The unresting wing.

Self relianse of the petrel.

up in the air, but usually a few inches above the water; and as he flies his long blackish legs hang down and his web feet seem to pat the surface of the storm waves with the lightest possible touch.

With such a flight he goes for days and nights (for aught we know for weeks and months) up and down the waves, darting through the troughs, slipping along smooth hollows, paddling up the sides of water wedges, mounting over drives of spray, delighting in wind and rain; and never quite so much at home as when the spindrift is flying. $\mathrm{He}$ does not stop to alight, even when he finds food; but keeps a beating wing and a dancing foot above it until the little hooked bill secures it. Then on and on again, knowing no r'esting place, knowing no home, now by the icebergs of the Antaretic, now with the storm waves of the Atlantie, as fearless of loneliness as of tempests, traveling where no other life is seen-the bravest. freest, most self-reliant bird ever known to man.

The gray-black wing of the stormy petrel has not solved the problem of perpetual motion; but it has suggested once again how happily nature fits her ereatures to their home and arms them for their special needs. What a 
life for a bird, condemned to solitude and storm and strife, marked for an unresting wanderer The soliup and down

"the fearful hollows of the barren sea!"

And yet, as with the octopus, are we quite sure that we have the petrel's point of view? Is he a lonely exile, an Ahasuerus of the sea? Is there no pleasure in existence for him? Surely nature never planned such perfect development without meaning to turn loneliness into society, hardships into pleasures, and exertion into joy. What is the storm to the well-lapped plunage, the seething wave to the finely webbed adversity. foot, or the winter gale to the masterful wing? Merely the playthings of existence, some of the stubborn eireumstances from which are wrung the joy of living.

The flight of the petrel, the incessant throb of his wings through so many opposing elements, his untiring spirit and determination to live and be happy even on a bourneless ocean, is there not in these a now-familiar lesson for The persistence of lific. us? Are they not onee more indicative, even typical, of the persistence of life and the insistence that the species shall not perish? Always where the conditions are so unfavorable that extinction would seem the only result at- 
The omnipresent energy

Fitness and beauty.

Coloring of the sen birds. tainable there nature puts forth an extra effort, launches a hardier life, is more triumphantly dominant than elsewhere. Petrels come and petrels go but the type remains. The dull gray wings flash their reflections in the wave-facets to-day as thousands of years ago. They shall always be as they have been, they shall always beat and hover and gather-fit emblem of that omnipresent energy that throughout creation keeps coming and going, backward and forward, weaving new threads into the fabric of life that the splendid tapestry shall not fade but endure and be a joy forever.

And always with energy, life, and fitness is the gift of beauty. To the sea bird is given not only grace in flight above all others, but also charm of color. These gray wings of the open sea whose neutral tints blend so easily with mist and fog and cloud, the white breasts that match the breaking foam, the black backs that scem to melt at night into the purple sea itself, are they not marvels to the eye though not glittering with all the hues of the rainbow? Their wonderful harmony with their sea background should acclaim their appropriateness, and, consequently, their beauty.

Blacks and whites and grays in uature's hands are never other than badges of distinction 
and refinement. For again, and still again, unto the least of her children nature has giren as much design and beauty as unto the greatest. Not alone for those that walk the earth or thread the lakes and rivers does she labor; but also for those that beat the coast and fly the unfrequented water-fields of the ocean. Gray Wings-they, too, are a part of the plan, they, plan. too, have a mission to fulfil, and they, too, have their portion of the life and care and wisdom of Creation. 


\section{CHAPTER XII}

\section{SHIPS THAT PASS}

Coming down to the shore, threading a way

Coming dow'n to the sea.

The native elemerit. through hills or fields or dunes, with what a thrill of joy, of exultation, we at last behold the outstretched sea! The sight gives one pause. The far-away shimmer of the surface, the great body of color, the myriads of dancing waves, the vastness of the expanse, hold the attention spell-bound. For the nonce the smell of salt air, the sound of surge, the wash of breakers, the scream of tern and gull, keep beating at our senses in vain. Perhaps we are silent or overcome or at least fearful lest we cry out with emotional feeling. And if we did we should not be exceptional or singular. When Xenophon and the retreating Ten Thousand finally came within sight of the Euxine the whole army shouted. The sea no doubt was a glimpse of home to them; and in a larger sense it may mean the same thing to us. For

"All mankind is thus at heart Not anything but what thou art And Earth, Sea, Man are all in each." 244 
There is, at times, a feeling common to every one of us that we are a part of the universal whole, that sometime in the history of the race we were more closely related to the elements than now; and that perhaps originally the sea was the cradle of us all.

But how long do we dream of our elemental origin, how long are we impressed or emotional or exclamatory over the immensity of the sea? ITe wander by the shore, we follow the rise and Emotions fall of trooping waves, wateh the rush of water up the beach, and presently, for all our love of the beautiful, we are looking at things and not seeing them. The mind becomes uneasy, lonely, somewhat afraid; and finally reverts to mankind and the doings of the race. Then the eyes no longer behold the sea. They sweep around the horizon not for the sapphire glow of the waves but for what the waves may tell of humanity, not for the gray wings that come The uneasy mind. and go along the hollows and the crests but for the white wings of ships that rise and fall.

A sail! a sail! How the vision strains at the distant spot of dull white! How elosely that spot is seanned for sign or signal of whence it eame or whither it goes! We have an interest, tant sail. a sympathy there. For each ship with her company and cargo that hovers along the distant 
The disappearing ship.

Watchers of the sea.

Ships that haice pussed. horizon stretching her wings for Good Hope or the Horn, is a venture that puts man's invention and supremacy to the test anew. And besides there go our friends and kindred. Will they come back from the roaring sea successful in their enterprise or will those sails fade into the Great Silence and never be heard from again? What wonder, indeed, that hopes and fears and prayers should go with her, and that eyes should strain after the white canvas until it drop below the verge?

It was always so. In all ages there have been watchers of the sea-tear-dimmed eyes following the disappearing sails, bright eyes watching the rising ones. A Scandinavian drakkar with its leather sail and dragon prow, beating seaward from some stubborn coast on warfare bent, or an Egyptian galley with its purple, perfumed sails, carrying a Cleopatra up to Rome, never yet sank below the distant rim but that dark eyes marked its disappearance. The headlands and beacon points have furnished lookouts for many centuries.

And in that time what ships have passed! Sails of skin, of papyrus, of bamboo, of wool, of hemp--lug sails, square sails, lateen sailsin brilliant procession have swept athwart the two immensities, their great wind areas darkly 
dyed with scarlet, orange, blue and purple. The gorgeous butterflies of commerce, chased by the eager winds from sea to sea-the winedark galleys of the Figean, the red and azure argosies of the Adriatic, the gilded galleons of the Atlantic-have gone their way. In deserted harbors and along unfrequented water ways of the East some reminders of them may still be seen; but the old order has changed and the erstwhile golden age of navigation has giren place to something new.

Yet the sea has never lacked for ships to sail it. With each generation are launched new hulls, new sails, new fears, new hopes. The harbor to-day sends forth ships as a hive its working bees, and each craft as she beats out to sea is followed by eager eyes and applauding voices. The interest has not diminished in the least. Nor has the beanty of the ship grown less. For there is a beauty of ships as of sea birds, though the association of thought is rather to the detriment of the former. The fairest wings of the most graceful pleasure yacht that ever rode a summer sea are but clumsy mechanism compared with the white wings of the albatross or the black wings of the frigate bird. Nothing of human device can and gray wings.

The butterflies of commerce.

The harbor to-day. match the design of nature. The true sailer 
is born not made. Yet considered by itself the sail boat is a marvel of grace; and to this latest day it is still a grand sight to see a full-rigged ship bowling down the bay, bound for the open sea,

"With all her bravery on, and tackle trim, Sails fill'd, and streamers waving, Courted by all the winds that hold them play."

And how splendidly picturesque she is as she

The fullrigged ship.

Colors of her sails.

foots it out to sea with her spread of silver canvas showing against the blue sky and slashed here and there by light and shade! She pitches and lifts, careens and rights again; and all her canvas goes rolling with her-not violently, but gently drifting like white clouds in summer weather. Perhaps at evening she is standing still upon the horizon, half-becalmed, flattened against a purple bank of sea mist, and the orange hues of sunset are weaving strange colors in her drooping sails; or, stranger still, if from the Golden Gate she beats out to sea against a yellow sunset, all her sails turn azure; or if the sun be red the sails assume a fairy green.

The sun is, indeed, a wonderful alchemist and loves to throw delicate, complementary and reflected colors on neutral grounds. And nothing could be a finer field than a great, white 
sail-exeept a great, eolored sail. The eruise of a yachting squadron up the Atlantic coast A white yachting in July, the schooners careening under clouds of white canras, is certainly impressive. Not only lightness of movement is there, but countless combinations of shadow and color as well. By comparison the fishing boats that put off from Ragusa or Corfu are heavy in their movements. The lateen sails sway easily enough, but the bareas ride low and eareen little. Color, however, saves them. A few miles away, where form and movement become less apparent, the yellow, orange, and red sails show merely as triangular spots on the blue sea; and blending as they do into the rosy strata of sea air they become marvelous in deptl of hue.

Nothing connected with ships is quite so colorful as this. The Venetian sails coming up the Adriatic at sunset-ruby lights upon a sea of pearl-have been pietured many times; but the gem-like quality of the coloring has never been painted. Compared with them the canvas of the Gloucester flcet moving toward the Venetion fishing Banks is a dismal gray, and the Conearneau boats, coming home at evening, appear as wedges of dull chocolate-brown. The sails of the Adriatie, famous sinee the days of the Bucentaur, are still wonderful to behold. Adriatic. 
The ocean steamer.

The steamer putting to sea.
But however much of actual beauty clings to a sail, and however much of traditional reverence bids us scorn an innovation, is there not something to be said for the grim, fire-spitting ocean steamer? In common with all steam devices the steamship has come in for a fair share of denunciation; but as a machine, as a resistless force, is there not something here to stir the pulses? As she sweeps down the harbor and out over the bar, flags streaming, black smoke trailing, wide wake rolling, what could be finer! She sits low down aft, she rises up clean and keen forward, her cutwater is as eager as a headsman's axe, her smoke stacks liave a slant astern as though ready for any wind or ware. What a sense of power is there! What can stop the passage of that dark conqueror! And she moves with no apparent effort. The source of power is not disclosed to the eye. Nor can the ear detect the beat of engines. The steel mass seems to be driven by a force as invisible as resistless.

No prayers to Oceanus, the parent of the gods, go up when the ocean liner puts to sea. Eolus is not invoked for favorable winds nor are the Tritons and Nereides put in good humor with promises and offerings. The ship of steel and steam seems to care little for the 
elements. The tremendous power in the engines carries her through wind and storm, through wave and spray. Nothing halts or The pouer holds her for more than a moment. As the waters come rushing at her there is an easy bend and sway to the long body; she rises and falls, rolls quietly with a broadside, pitches sharply with a bead sea; but there is no pause, no stop. The steady thrust of the screws keeps driving her ever on and on. Far away at sea her motion is still apparent, and finally when she is hull down beyond the rim, and only the black banner of smoke trailing along the horizon tells where she "blows," we still feel that she is moving, shouldering the waves away, The stecty drive forpushing on and on; methodically, mechanically if you will, but still resistlessly.

The mechanism and the method become almost human in their stubborn perseverance when the vessel is steaning in storm against fierce head winds. There is the deep plunge of the bow in the waves, the alternate lift of the stern out of water, the swift racing of the exSteaming through storm. posed screws for a few moments; and then the settling down again to a steady thump-thump, thump-thump, thump-thump! The waves may board her and break davits, bridges, and stanchions, she may pitch and roll till cabin and 
The persistent engines.

The picturesulue ship at sea.

hold are a series of crashes and smashes, but those indomitable engines keep up their pulsations. You lie awake in the middle of the night clinging to your berth, hearing the whiplike swish of the spray flying by the port hole, listening to the roar of the wind in the rigging, feeling the vessel pitch and stagger under you, and perhaps wondering if rivets and plates of steel can long hold out against such wrenching; but still beneath you, skipping no beat, is the welcome thump-thump, thump-thump, thumpthump of the engines. She was designed to defy the winds and fight the elements and she does it-with some groanings from strained partition, beam, and girder it may be, but still she does it.

All ships that come and go along the waterways, whether by steam or by sail, have pictorial importance in the panorama of the seas. Not pleasure yacht or ocean "greyhound" alone, not the lateen sails of Venice or the gray wings of Newfoundland; but the lone bark that stands up along the horizon like a square tower, the coasting schooner that trails her flat sails along some rocky shore, the tank steamer slowly moving with her own cloud of smoke, the big freighter lumbering up and down the distant waves-they all have their measure of 
beauty in the scene. Even the battleship and the arrow-like torpedo boat, if we could forget their grim mission on the seas, might prove attractive. Certainly their graceful motion, their enormous rush through the water, the inherent power felt in every push or curve or bend of them, commands not only respect but admiration. Perhaps we are too near to them now to see them sympathetically, but when these times shall become the "good old times," there will be poetry and to spare about the present-day thunderers of the seas.

Romance usually clings to things that are past and eventually all the ships pass on-pass out. Ribs of oak and plates of steel and turrets of nickel find a common resting place sooner or later. It is as often in the depths as on the shore, and every coast has its graveyard where, far down in the darkness, schooner, brig, barkentine, steamer and cruiser nestle side by ing place side in the soft ooze of the bottom and know the wind and the wave no more. Perhaps with them and near them are scattered the bones of many a crew that went down with the ship, lashed in the rigging or caught under hatehes. And perhaps again no word ever came back from the sea to tell the fate of either men or ships. This it is that is accounted the "mys- 
The tragedy of the sea.

The unthinking sea not "rapocious."

The grim Bea tales furnished by men. tery" and the "tragedy" of the sea. The destruction of the sea life that goes on beneath the surface day in and day out, the killing and devouring, the slaughter of untold millions for food, are accepted as matters of course, things of no great moment; but when the destruction extends to man, when two hundred men die in the sea instead of in the air, the event is a "horror" and the sea is referred to as "rapacious" or as a "remorseless monster."

But the unthinking sea is it so much more "remorseless" than the other elements or more "rapacious" than the personified deities of men? Did not the gods at Ilios spin the web of death for some that others in the time to come might have a song? And do not all the elements-all great Nature's self at timesturn "red in tooth and claw" and spread destruction up and down the world? The sea by itself considered is neither "mysterious" nor "tragie" nor "rapacious"; it is simply the sea.

And whatsoever of evil may be found upon the waters has it not followed upon the footsteps of man? The wars of maritime states, the oppression of eonquerors, the atrocities of the slavers, the ravages of the buccaneers, llave always furnished forth the grim sea 
tales. What pages smeared with blood and reeking with smoke they are! We read the record, count over the destruction-the wanton waste by fire and sword of life and loveliness -and sadly wonder that such things could ever be. Nor does the present furnish forth a less ghastly story. There is no more of the pirate's The real horror of brigantine flying the black flag upon the high seas; but the battle ship of civilization is with us to deal out, in the name of liberty and enlightenment, a destruction more violent and more widespread. Is the change very much for the better? Is death hurled from a machine gun preferable to walking the plank? And in all time, in all history, has not the real "horror" of the sea been not storm but man; and the "remorseless monster" not the wave but man's beautiful engine of destruction, the ship?

If the tale were truly told it would be romantic only in its hideousness. For the bloodshed and the ruin of it have not resulted from the pursuit of life or happiness or knowledge or beauty or even fair commerce. From the beof gold and ginning the quest of the Argonauts has been the its results. golden fleece. Men have rentured and endured and labored and died for mere gold. That gilded lure drew on the early explorers through harrowing hardships to the most dis- 
The hardships of the explorers.

Searching for gold at the north.

Sunken treasures.

tant seas. Even the Aretic regions were ransacked in the search. For at one time the tradition obtained that under the Northern Lights, under the pole was hidden gold in fabulous quantities, guarded by gnomes and goblins as the Rheingold by Mimi and the Rhine Maidens. But the seekers found only starvation and the cold of death. The vast unknown of the Arctic, the weird lights of summer, the brilliant coloring of the auroras, the twilight skies, the walls of ice crystal, the waves of glass, the purple shadows upon snow and ice were all lost upon the voyagers. They were bent upon a more sordid mission.

Even to this day, when the treasure-tales have grown somewhat threadbare, the forecastle still listens to accounts of Kidd's wealth buried on Gardiner's Island; to the tale of the Spanish galleon "San Pedro" sunk in the Margarita Channel on the Central American coast so many years ago, with all her golden images and precious stones and thirty millions in doubloons; to the legend of the French frigate, "La Lutino" which went down in the Zuider Zee with three hundred and thirty golden bars beside bags and kegs of coin. The glitter of gold still dazzles.

The races of to-day have been, in some re- 
spects, true enough deseendants of the Argonauts. The oceans are still harried and quarreled over in the name of gain; and that race hatred, which has so often turned the sea into a plain of battles and tinged the blue waves crimson, has been the natural consequence of the pursuit. Yet not every ship has flown the red flag of hate, and not every crew has been on conquest bent. The peaceful trader has always skirted the eoasts. The honest merchantman, the carrier, the middleman of the nations with his cargoes of stuffs, dyes, jewels and fair produce runs back to Egyptian days. Even with the great discoverers of Spain there went out caravels on missions of peace and good-will to men; and, in our own time, lines of fullrigged ships have gone around the Capes in the Oriental trade and swift-traveling clippers have come and gone to Europe and to China, to Australia and the islands of the seas, in the interests of morality and religion as well as commerce.

They still come and go, faster now with steam than in the days of the famous "Dreadnought" and "Red Jacket"; and the compensation for envy and race hatred is coming in with a better understanding among the nations. Moreover the growth of commerce and the

Race

hatred on

the sca.
The early carriers and merchantmen. 
Growing appreciation of sea beauty.
Atlantic crossings. speed of travel have done much to bring people together, done much to educate and enlighten mankind. The sea instead of being the impassable waste it once was has now become the highway of the world, and those who travel it have not only come to a truer comprehension of their fellows, but they have grown to love the highway and the journey along it.

For with a knowledge of the sea there is beginning to dawn in these latter days some appreciation of its purpose, its uses, and its superlative beauty. Now as the ocean steamer puts out for Europe with five hundred or a thousand on her passenger list not a few of that number have a pleasure in the thought:

"Eastward, as far as the eye can see Still eastward, eastward endlessly The sparkle and tremor of purple sea."

The crossing means to them something more than a week of discomfort in the cabin; and the sea, as they follow its changes day by day and see its waters run the gamut of blue, green, violet and purple, becomes the most wonderful of all the elements. Year by year the wonder grows. All the brightness of the earth is but the sea's reflection. The life, the energy, the color of the globe, the opaline vapors blown 
about the heavens, the sky and the gorgeous staining of the horizon clouds, come from the sea. There is nothing it does not share, no splendor that it has not illuminated, no beauty The supreme element that it has not made. The sea is above all, the supreme element!

And yet from that steamer deck sometimes sad eyes look out at night upon the rush of waters with their flashing white caps, and in the tumult of the stormy surface see only the likeness to the human struggle, the maddening strife for position and power,

"the turbid ebb and flow Of human misery."

Inevitably will come with such a vision the uselessness of endeavor, the hopelessness of conflict, the certainty of defeat and death. If death then why postpone it? Why drag on another day, another year, only to be beaten down and overwhelned at last?

But that way lies madness. And for the mad the sea has her own special lure. The foaming caps keep beckoning with long, white fingers, The lure and every wave that races down the steamer's side seems calling "Come! Come!" And men from time to time-mad men-have answered with a sudden spring over the rail and into the 
dark sea; a wild plunge, feared and yet urged by some demoniac impulse. Perhaps contact with the water has suddenly dispelled delusion and the repentant one has come strangling to the surface with a frenzied cry for help. Who hears? And what help can avail in night and The suicide. storm? There is a swift rush past of the black side of the steamer, a useless clutch at it in the dark, the whirl and seethe and bubble of the water churned by the screws, and a glimpse of a ship's taffrail vanishing in darkness. Then the beat of crested waves, the fierce slash of spray across the eyes, the rush of smothering seas over the defenseless head; and in the gray morning gulls hovering and calling over a white face awash on the waves.

But the analogy is misleading. Life is not

Neither

life nor the sea always stormtossed.

The maintenance of life. like the tumult of a storm-tossed sea. It has its quiet periods, its hopeful years, its joys and triumphs and successes. The sea is not always agitated. It has its days of calms, its mornings of brilliancy, its noons of drowsiness, its evenings of splendor. And the great law of nature that all life shall struggle for existence, that all the old shall pass away and be superseded by the new, that the type shall remain though the unit perish, is the only conceivable way of maintaining the order of the universe and fend- 
ing off extinction and decay. What matters it that the individual is lost? What matter that the sea adds here or destroys there? The energy and purity and life of it still continue.

And shall continue. The great waters should be the last to go. That we do not stay to the The sea the last to go. end, if there be an end, is of no great moment. We have played our part and entered into the fulness of being, struggling with the energy within us, and enjoying the struggle. Nor is our output scattered to the winds. The new generations inherit and in them is the old life continued. It should not be a sad thought that when we, like ships, have passed on, the world will last, that its beauty will always be renewed, and that others will enjoy what we have known. Rather should it be wished that the fabric builded so perfectly, fashioned so wonderfully, might endure forever; and that the newer eyes as they open to the light might see still further and more truly than our own. Each coming man in vision counts himself beyond his father; but it may be the world that changes rather than our eyes. In the time to come who can say what finer garmenting shall clothe the hills, what greater splendor shall adorn the sea!

Yet may the beauty that has been, continue! May ships sail on and eyes still follow them till 
The beauty that shall be. darkness settle in the purple east; may gray wings come and go along the deep wave-hollows and sea weeds stream beneath in swirling currents and blue waves pour upon the shell-strewn beaches where crumbling cliff and broken promontory look outward at the distant ocean! And may that ocean with its shifting surface, in calm or storm, be grander far and more sublime than ever; and may the eyes that watch see with a calmer faith and brighter the sun and moon rise up from out the wave, and in the growing dusk of years behold new stars of promise come forth with tremulous splendor to shine upon the Opal Sea. 


\section{BOOKS BY JOHN C. VAN DYKE}

Professor of the History of Art in Rutgers College PUBLISHED BY CHARLES SCRIBNER'S SONS

\section{The Meaning of Pictures}

With 31 full-page illustrations. I2mo, \$1.25 net

"It may be questioned if any other book of its scope has ever shown 'the meaning of pictures' in a way that will make it so clear to the average English reader."

-The Dial.

"A book that is always calm and cool and right."

-New York Evening Post.

"r Essentially sound and rational." -Outlook.

" We could ask nothing better for the training of art taste in America than the wide circulation and careful reading of this sound and sensible introduction."

- The Congregationalist.

"An unusual quality in art criticism, plain conımon sense with a delightful avoidance of technical jargon."

-New York Sun.

“' 'The Meaning of Pictures' has in abundant measure a happy kind of originality, the most genuine sort of helpfulness, and rare power to stimulate."'-Boston Herald. 


\title{
BY PROFESSOR JOHN C. VAN DYKE
}

\section{Nature for Its Own Sake}

\section{First Studies in Natural Appearances}

\author{
r2mo, $\$ \mathrm{r} .50$
}

"No one can read it without having his knowledge of nature enlarged, his curiosity quickened, and his sensitiveness to the beauty that is all about him in the world increased and stimulated." - Chicago Tribune.

" He writes clearly and simply and indulges in little rhetoric or false sentiment. His ' first studies,' therefore, will probably reveal to many people many things of which they were unaware." -The Nation.

"A series of interesting and distinctly original essays." -Philadelphia Public Ledger.

"A book of uncommon merit, first, in its point of view, and, second, in the peculiar skill with which the subject of nature is handled." -Washington Post.

"A book on nature widely different from anything yet written, and fresh, suggestive, and delightful.",

-New York Times.

"A book for all nature lovers. . . . A most delightful vade mecum."

- Bliss Carman in New York Commercial Advertiser. 


\section{BY PROFESSOR JOHN C. VAN DYKE}

\section{The Dese r t}

Further Studies in Natural Appearances

With frontispiece. 12mo, \$1.25 net

"The reader who once submits to its spell will hardly lay it aside until the last page is turned."

-The Spectator (London).

"This charming volume comes as strong wine indeed after the tepid rose-water of books dealing with snails and daffodils in suburban gardens. Mr. Van Dyke unquestionably knows his desert; he has the true wanderer's eye for its essential fascination." -The Atbenceum (London).

"No virgin rush of young impressions, but an adult mingling of vision and criticism in a style that engages without startling the attention." - London Academy.

"Strange and curious reading, this book of the desert, and has all the fascination of things unaccustomed."

-New York Tribune.

"The writer's personality is carefully subordinated, but one cannot help feeling it strongly; that of a man more sensitive to color than to form, enthusiastic, but with a stern hand on his own pulse." - Atlantic Monthly. 


\section{BY PROFESSOR JOHN C. VAN DYKE}

\section{Art for Art's Sake}

\section{Seven University Lectures on the Technical Beauties of Painting}

\section{With 24 reproductions of representative}

paintings. 12mo, $\$ 1.50$

"One of the best books on art that has ever been published in this country." - Boston Transcript.

"We consider it the best treatise on the technic of painting for general readers." - The Nation.

“Mr. Van Dyke is very good reading indeed, and withal remarkably clear and precise in explaining much that shapes itself but hazily in the brain of those interested in art." -London Spectator.

"I do not know that there is a book in English from which one can learn more of what pictures are and why they are admired."-DR. Talcott Williams.

"Has all the recommendations that are to be looked for in essays of the kind. They take a broad survey, they deal with the points that it is worth while to know about, they are perfectly lucid, and they are very charming in their literary art." - New York Sun.

"Temperate and appreciative."-Atlantic Montbly. “Written in an easy, entertaining style."

—New York T'ribune. 







\section{UNIVERSITY OF CALIFORNIA LIBRARY}

\section{Los Angeles}

This book is DUE on the last date stamped below. 
